\title{
Direct Manipulation of Metal Imido Geometry: Key Principles to Enhance C-H Amination Efficacy
}

\author{
Yunjung Baek, Elisabeth T. Hennessy, and Theodore A. Betley* \\ Department of Chemistry and Chemical Biology \\ Harvard University \\ 12 Oxford Street, Cambridge, Massachusetts 02138
}

Page

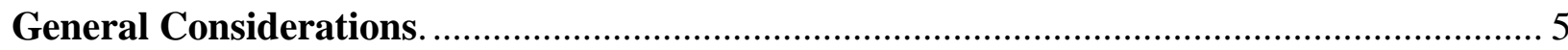

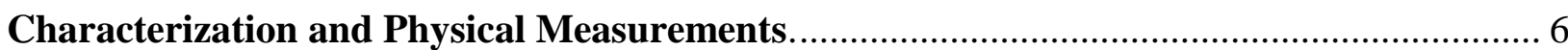

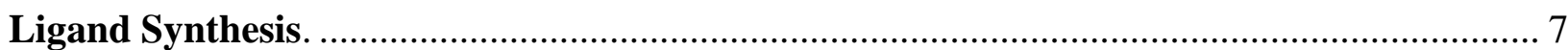

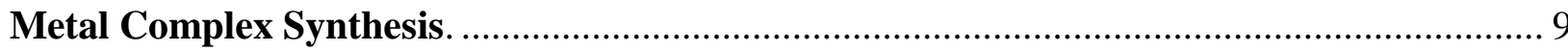

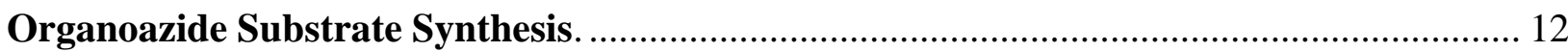

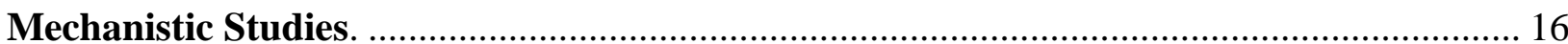

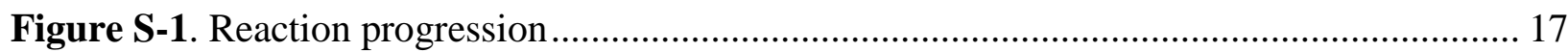

Figure S-2. Changes in ${ }^{1} \mathrm{H}$ NMR chemical shifts as the reaction proceeds ............................. 18

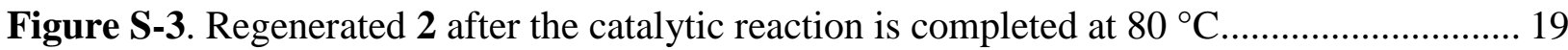

Figure S-4. Rate of formation of $\mathbf{6}(\mathrm{mM} / \mathrm{min})$ versus concentrations of imido 7 (mM)........... 20

Table S-1. Averages and standard errors for the observed initial rates with varying

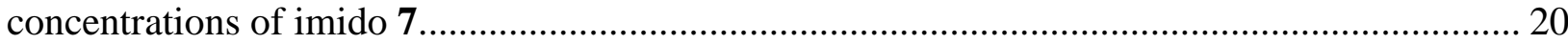

Figure S-5. Rate of formation of $\mathbf{6}(\mathrm{mM} / \mathrm{min})$ versus concentrations of azide $\mathbf{5}(\mathrm{mM})$............. 21

Table S-2. Averages and standard errors of the observed initial rates with varying concentrations of azide

Figure S-6. Job plot obtained at $25^{\circ} \mathrm{C}$ in benzene- $d_{6}$ with [2] + [pyridine] $=8.85 \mathrm{mM} \ldots \ldots \ldots . . . .22$

Table S-3. Chemical shifts (ppm) of 2 as a function of [pyridine] at $25{ }^{\circ} \mathrm{C}$ in benzene- $d_{6} \ldots \ldots . . .23$

Figure S-7. Formation of $\mathbf{6}$ as a function of [pyridine- $\left.d_{5}\right]$.............................................. 24

Table S-4. Averages and standard errors of the rates at 30\% formation of 6 as a function of

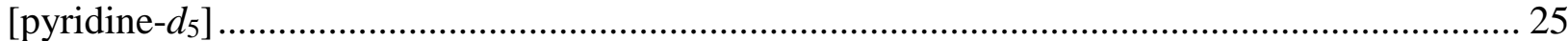

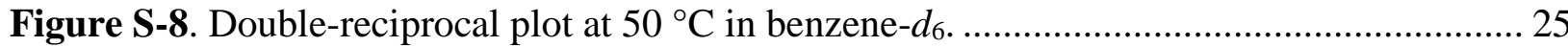

Figure S-9. Proposed catalytic cycle in the presence of pyridine......................................... 26

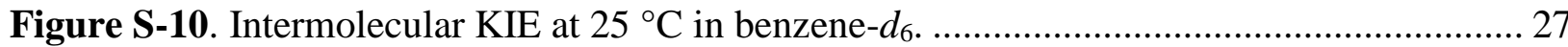

Table S-5. Averages and standard errors of the observed initial rates with $\mathbf{2}$ and azide $\mathbf{5}-\boldsymbol{d}_{\mathbf{2}} \ldots . . .28$ 


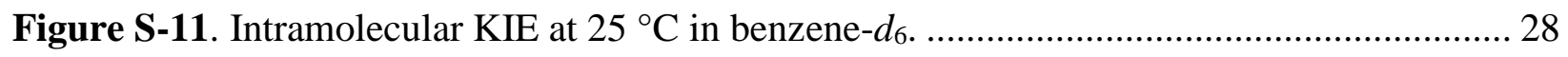

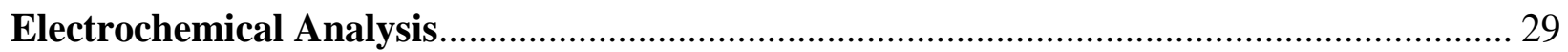

Figure S-12. Cyclic voltammogram of $\left({ }^{\mathrm{Tr}} \mathrm{L}\right) \mathrm{Co}(2)$ in 1,2-difluorobenzene .............................. 29

Figure S-13. Cyclic voltammogram of $\left({ }^{\mathrm{Tr}} \mathrm{L}\right) \mathrm{Co}(2)$ in 1,2-difluorobenzene at varying scan rates

Figure S-14. Cyclic voltammogram of $\left({ }^{\mathrm{Tr}} \mathrm{L}\right) \mathrm{Co}(2)$ in 1,2-difluorobenzene at varying scan rates 30

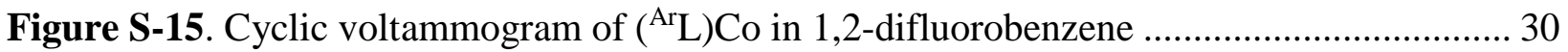

Figure S-16. Cyclic voltammogram of $\left({ }^{\mathrm{Tr}} \mathrm{L}\right) \mathrm{Co}(\mathrm{NAd})(\mathbf{3})$ in 1,2-difluorobenzene..................... 31

Figure S-17. Cyclic voltammogram of $\left({ }^{\mathrm{Ar}} \mathrm{L}\right) \mathrm{Co}(\mathrm{NAd})(\mathbf{8})$ in 1,2-difluorobenzene .................... 31

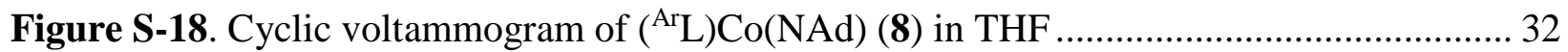

Figure S-19. Stacked cyclic voltammogram of $\left({ }^{\mathrm{Ar}} \mathrm{L}\right) \mathrm{Co}(\mathrm{NAd})(\mathbf{8})$ obtained at room temperature

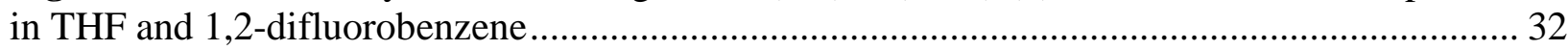

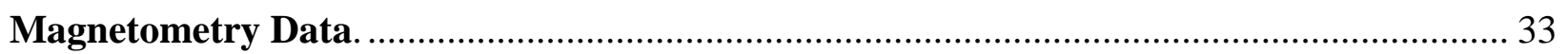

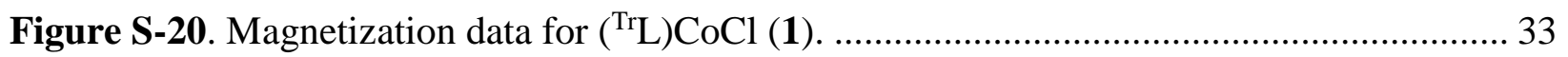

Figure S-21. Variable temperature magnetic susceptibility data of 1 .................................... 33

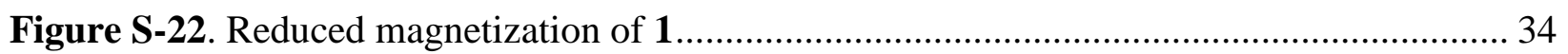

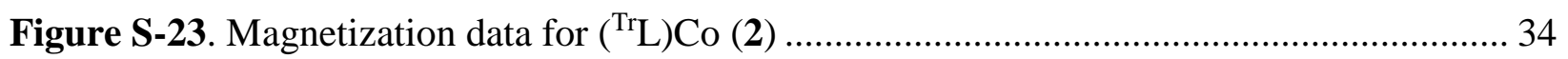

Figure S-24. Variable temperature magnetic susceptibility data of 2 .................................. 35

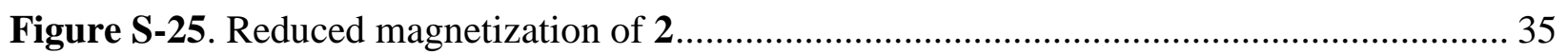

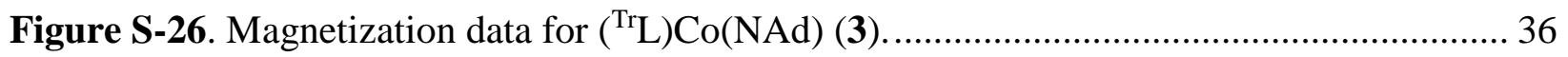

Figure S-27. Variable temperature magnetic susceptibility data of 3 .................................. 36

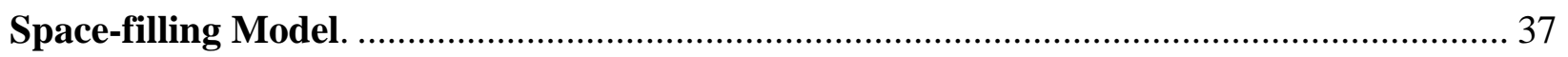

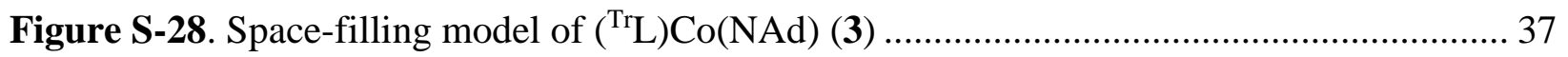

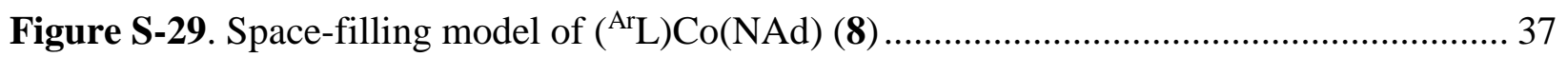

Characterization of Pyrrolidine Products. .................................................................... 38

Computational Methods for Probing $\mathbf{p} K_{\mathrm{a}}$ of Cobalt(II) Amide Complexes....................... 41

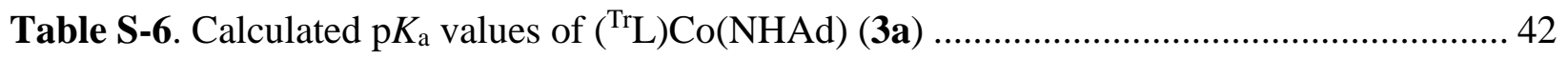

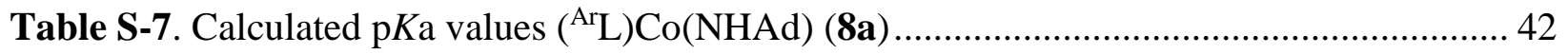

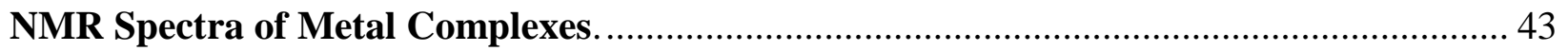

Figure S-30. $600 \mathrm{MHz}{ }^{1} \mathrm{H}$ NMR spectrum of $\left({ }^{\mathrm{Tr}} \mathrm{L}\right) \mathrm{CoCl}(\mathbf{1})$ in benzene-d6. ........................... 43

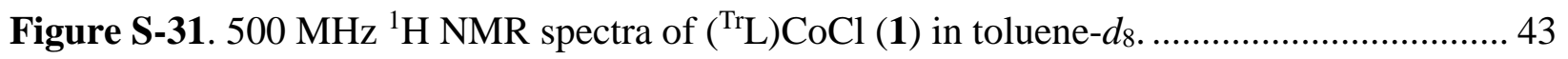

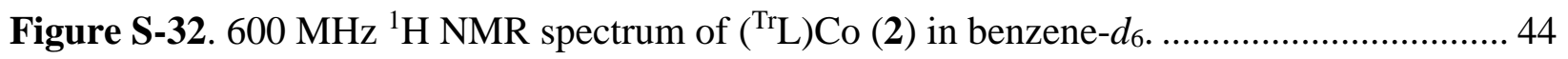

Figure S-33. $500 \mathrm{MHz}$ Variable temperature ${ }^{1} \mathrm{H}$ NMR spectra of $\left({ }^{\mathrm{Tr}} \mathrm{L}\right) \mathrm{Co}(2)$ in toluene- $d_{8} . . . . .44$

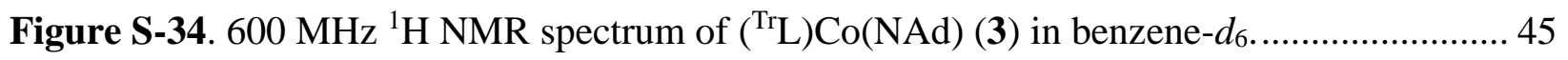


Figure S-35. $125 \mathrm{MHz}{ }^{13} \mathrm{C}\left\{{ }^{1} \mathrm{H}\right\}$ NMR spectrum of $\left({ }^{\operatorname{Tr}} \mathrm{L}\right) \mathrm{Co}(\mathrm{NAd})(3)$ in benzene-d $d_{6} \ldots \ldots \ldots \ldots \ldots . . . . . . .45$

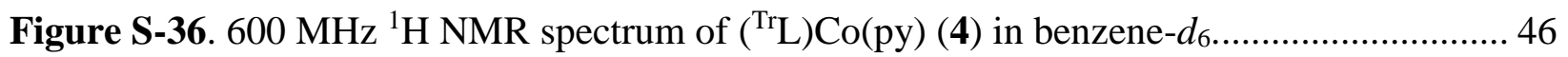

NMR Spectra of Organic Compounds......................................................................... 47

Figure S-37. $600 \mathrm{MHz}{ }^{1} \mathrm{H}$ NMR spectrum of $\left({ }^{\mathrm{Tr}} \mathrm{L}\right) \mathrm{H}$ in chloroform- $d$. .................................... 47

Figure S-38. $125 \mathrm{MHz}{ }^{13} \mathrm{C}\left\{{ }^{1} \mathrm{H}\right\}$ NMR spectrum of $\left({ }^{\operatorname{Tr}} \mathrm{L}\right) \mathrm{H}$ in chloroform-d.......................... 47

Figure S-39. $600 \mathrm{MHz}{ }^{1} \mathrm{H}$ NMR spectrum of 5-(4-fluorophenyl)-2-methylpentan-2-ol in chloroform- $d$.

Figure S-40. $125 \mathrm{MHz}{ }^{13} \mathrm{C}\left\{{ }^{1} \mathrm{H}\right\}$ NMR spectrum of 5-(4-fluorophenyl)-2-methylpentan-2-ol in chloroform- $d$.

Figure S-41. $500 \mathrm{MHz}{ }^{1} \mathrm{H}$ NMR spectrum of 1-(4-azido-4-methylpentyl)-4-fluorobenzene in chloroform- $d$.

Figure S-42. $125 \mathrm{MHz}{ }^{13} \mathrm{C}\left\{{ }^{1} \mathrm{H}\right\}$ NMR spectrum of 1-(4-azido-4-methylpentyl)-4-fluorobenzene in chloroform- $d$.

Figure S-43 600 MHz ${ }^{1} \mathrm{H}$ NMR spectrum of 5-(4-fluorophenyl)-2,2-dimethylpyrrolidine in chloroform- $d$. 50

Figure S-44. $125 \mathrm{MHz}{ }^{13} \mathrm{C}\left\{{ }^{1} \mathrm{H}\right\}$ NMR spectrum of 5-(4-fluorophenyl)-2,2-dimethylpyrrolidine in chloroform- $d$. 48

Figure S-45. $600 \mathrm{MHz}{ }^{1} \mathrm{H}$ NMR spectrum of in 2-methyl-1-azaspiro[4.5]decane chloroform- $d$.

Figure S-46. $125 \mathrm{MHz}{ }^{13} \mathrm{C}\left\{{ }^{1} \mathrm{H}\right\}$ NMR spectrum of 2-methyl-1-azaspiro[4.5]decane in

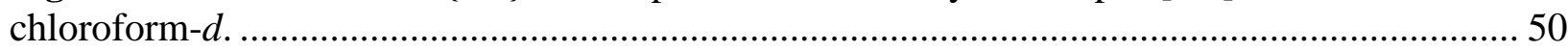

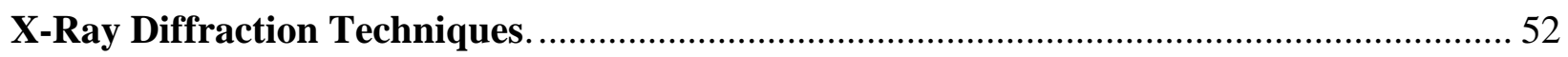

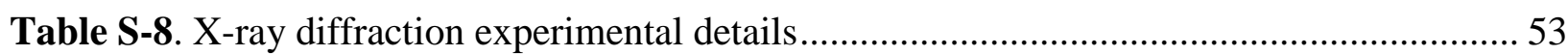

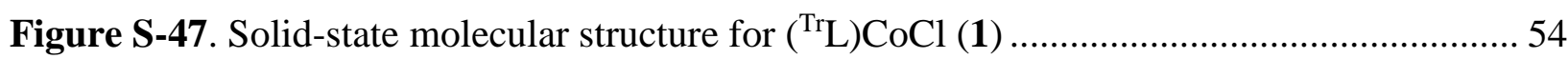

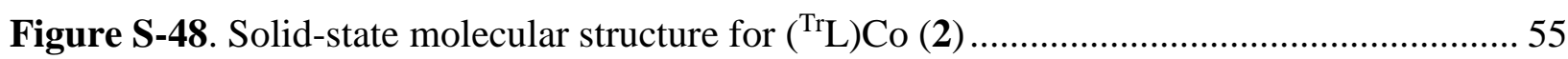

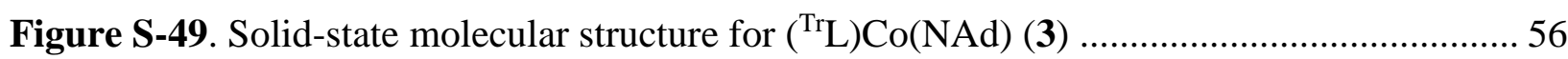

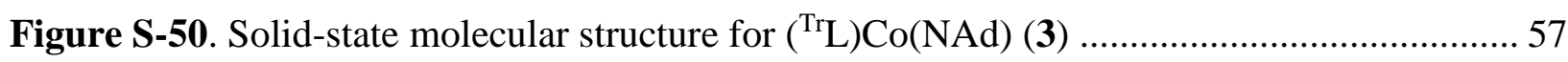

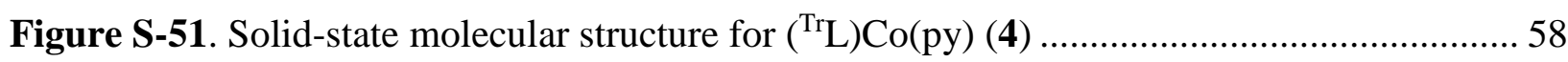

Computational Methods for Complex 3..................................................................... 59

Table S-9. Summary of the geometry optimized results of $\left({ }^{\operatorname{Tr}} \mathrm{L}\right) \mathrm{Co}(\mathrm{NAd})(3)$.......................... 59

Figure S-52. Geometry optimized molecular structure of $\left({ }^{\mathrm{Tr}} \mathrm{L}\right) \mathrm{Co}(\mathrm{NAd})(3)$ with an $S=0$ spin

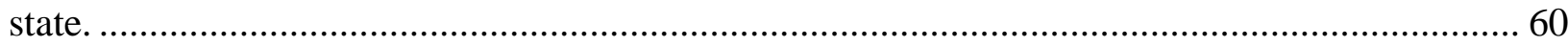

Figure S-53. Geometry optimized molecular structure of $\left({ }^{\operatorname{Tr}} \mathrm{L}\right) \mathrm{Co}(\mathrm{NAd})(3)$ with an $S=1$ spin state.

Figure S-54 Geometry optimized molecular structure of $\left({ }^{\mathrm{Tr}} \mathrm{L}\right) \mathrm{Co}(\mathrm{NAd})(3)$ with an $S=2$ spin state.

Figure S-55. Geometry optimized molecular structure of $\left({ }^{\mathrm{Tr}} \mathrm{L}\right) \mathrm{Co}(\mathrm{NHAd})(\mathbf{3 a})$. 63 


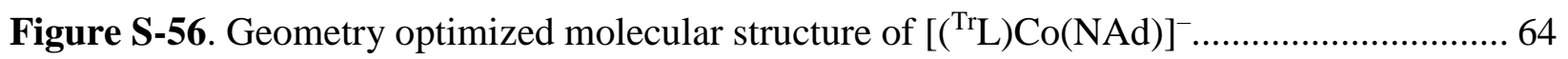

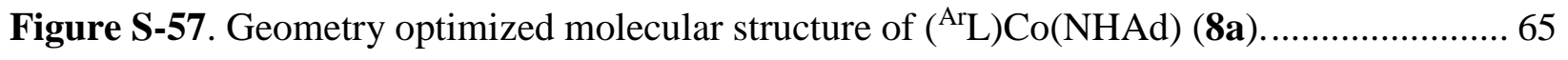

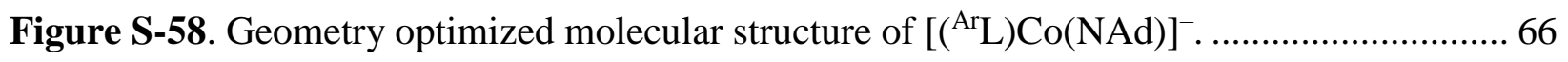

Table S-10. Coordinates of optimized molecular structure for $\left({ }^{\mathrm{Tr}} \mathrm{L}\right) \mathrm{Co}(\mathrm{NAd})(3)$................... 67

Table S-11. Coordinates of optimized molecular structure for $\left({ }^{\mathrm{Tr}} \mathrm{L}\right) \mathrm{Co}(\mathrm{NAd})(\mathbf{3})$................... 69

Table S-12. Coordinates of optimized molecular structure for $\left({ }^{\mathrm{Tr}} \mathrm{L}\right) \mathrm{Co}(\mathrm{NAd})(\mathbf{3})$................... 72

Table S-13. Coordinates of optimized molecular structure for $\left({ }^{\mathrm{Tr}} \mathrm{L}\right) \mathrm{Co}(\mathrm{NHAd})(\mathbf{3 a})$................ 75

Table S-14. Coordinates of optimized molecular structure for $\left[\left({ }^{\operatorname{Tr}} \mathrm{L}\right) \mathrm{Co}(\mathrm{NAd})\right]^{-}$..................... 78

Table S-15. Coordinates of optimized molecular structure for $\left({ }^{\mathrm{Ar}} \mathrm{L}\right) \mathrm{Co}(\mathrm{NHAd})(\mathbf{8 a})$............... 81

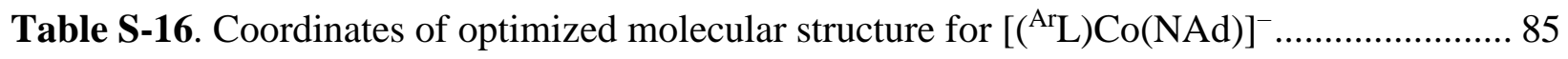

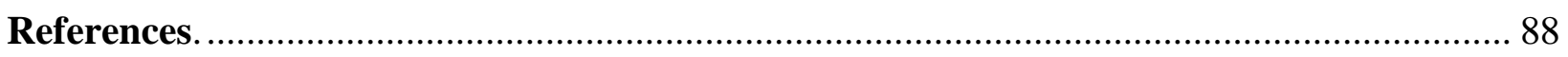




\section{General Considerations.}

All manipulations of metal complexes were carried out in the absence of water and dioxygen using standard Schlenk techniques, or in an MBraun inert atmosphere drybox under a dinitrogen atmosphere. All glassware was oven dried for a minimum of 1 hour and cooled in an evacuated antechamber prior to use in the drybox. Benzene, hexanes, and tetrahydrofuran were dried over 4 $\AA ̊$ molecular sieves (Strem) prior to use. 1,2-Difluorobenzene was purchased from Oakwood and was degassed and stored over $4 \AA$ molecular sieves prior to use. Chloroform- $d$ was purchased from Cambridge Isotope Labs and used as received. Benzene- $d_{6}$ and pyridine- $d_{5}$ were purchased from Cambridge Isotope Labs and were degassed and stored over $4 \AA$ molecular sieves prior to use. Pyridine was purchased from Aldrich and was degassed and stored over 4 Å molecular sieves prior to use. Pyrrole, pyridinium $p$-toluenesulfonate (PPTS), 2,3-dichloro-5,6-dicyano-p-benzoquinone (DDQ), 1-azidoadamantane, trityl chloride, aluminum trichloride, azidotrimethylsilane, methylmagnesium bromide solution (3.0 $\mathrm{M}$ in diethyl ether), ferrocene, tetrabutylammonium hexafluorophosphate, 1,3,5-trimethoxybenzene, and sulfuric acid were purchased from Aldrich and used as received. 4-(4-Fluorophenyl)butanoic acid was purchased from Oakwood and used as received. Boron trifluoride diethyl etherate and anhydrous cobalt(II) chloride were purchased from Strem and used as received. Celite ${ }^{\circledR} 545$ (J. T. Baker) was dried in a Schlenk flask for 24 hours under dynamic vacuum while heating to at least $150{ }^{\circ} \mathrm{C}$ prior to use in a drybox. Silica gel 32-63 $\mu$ (AIC, Framingham, MA) was used as received. 


\section{Characterization and Physical Measurements.}

${ }^{1} \mathrm{H}$ and ${ }^{13} \mathrm{C}$ NMR chemical shifts are reported relative to $\mathrm{SiMe}_{4}$ using the chemical shift of residual solvent peaks as reference. Elemental analyses were carried out on a Perkin Elmer 2400 Series II CHNS/O analyzer. Cyclic voltammetry was performed with a CHI660D potentiostat using a threeelectrode cell with a glassy carbon working electrode, a platinum wire as the counter electrode, and a $\mathrm{Ag} / \mathrm{AgNO}_{3}$ reference electrode. All of the potentials are referenced to the $\mathrm{Fc} / \mathrm{Fc}^{+}$couple. All of the measurements were done under a dinitrogen atmosphere. Magnetic data were collected using a Quantum Design MPMS-5S SQUID magnetometer. Measurements were obtained for finely ground microcrystalline powders restrained in a frozen eicosane matrix within polycarbonate capsules. Samples were prepared under a dry nitrogen atmosphere by packing the powder in a gelcap and adding warm liquid eicosane, which formed a solid wax upon cooling. DC susceptibility measurements were collected in the temperature range 5-300 K under a dc field of 5000 or 10000 Oe. DC magnetization measurements were obtained in the temperature range 1.8 $10 \mathrm{~K}$ under dc fields of 1,4 , and $7 \mathrm{~T}$. The susceptibility data was corrected for contributions from the sample holder and eicosane, as well as the core diamagnetism of the sample using Pascal's constants.

$$
\chi_{m}=\frac{\chi M}{m H}
$$

Molar susceptibilities were calculated from $\left(\chi_{\mathrm{m}}\right)$ by converting the calculated magnetic susceptibility $(\chi)$ obtained from the magnetometer according to Eq. S.1. The reduced magnetization data were fit using PHI. ${ }^{1}$ 


\section{Ligand Synthesis.}

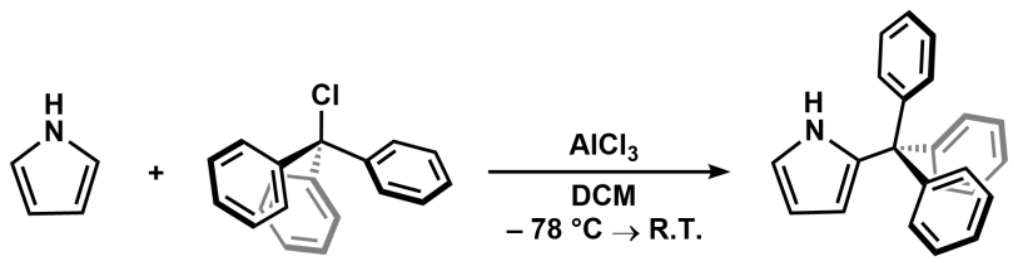

2-trityl-1H-pyrrole: An oven-dried $2 \mathrm{~L}$ Schlenk flask was charged with pyrrole $(48.1 \mathrm{~g}, 717$ mmol, 10 equiv) and $500 \mathrm{~mL}$ of dichloromethane (DCM) under $\mathrm{N}_{2}$. The solution was cooled to $-78{ }^{\circ} \mathrm{C}$ using a cooling-bath of acetone and dry ice. To a stirring solution, $\mathrm{AlCl}_{3}(19.1 \mathrm{~g}, 143$ mmol, 2.0 equiv) was added followed by a slow addition of a solution of tritylchloride ( $20 \mathrm{~g}, 71.7$ mmol, 1.0 equiv) in $200 \mathrm{~mL}$ DCM at $-78{ }^{\circ} \mathrm{C}$. The resulting reaction mixture was slowly warmed up to room temperature and stirred for an additional 4 hours. The reaction mixture was quenched with aqueous $\mathrm{NaHCO}_{3}$ and extracted three times with ethyl acetate. The combined organic fractions were dried over anhydrous $\mathrm{MgSO}_{4}$ and concentrated by rotary evaporation to yield a pale brown solid. The solid was dissolved in DCM and filtered through a plug of silica with $100 \%$ DCM as an eluent. The filtrate was concentrated in vacuo to afford the clean product as a white solid $(10 \mathrm{~g}, 45 \%)$. Spectral data were consistent with previously reported characterization of the product. $^{2}$

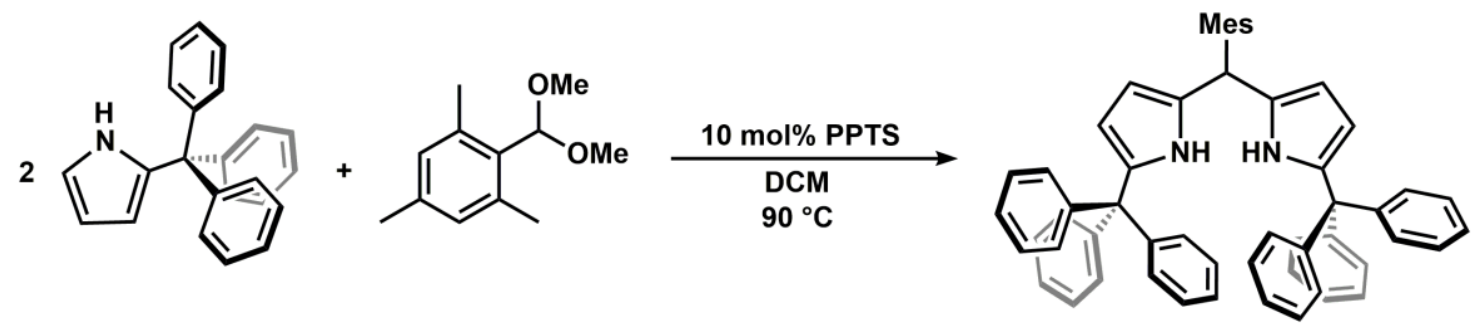

5,5'-(mesitylmethylene)bis(2-trityl-1H-pyrrole): In a glove box, an oven-dried $1 \mathrm{~L}$ air-free storage flask was charged with 2-trityl-1H-pyrrole (9.00 g, $29.1 \mathrm{mmol}, 1.0$ equiv), 2(dimethoxymethyl)-1,3,5-trimethylbenzene ( $2.83 \mathrm{~g}, 14.5 \mathrm{mmol}, 0.5$ equiv), and $250 \mathrm{~mL}$ of dry DCM. To a stirring solution, pyridinium $p$-toluenesulfonate $(0.73 \mathrm{~g}, 2.91 \mathrm{mmol}, 0.1$ equiv) was added and the flask was placed under partial vacuum. The reaction mixture was stirred at $90{ }^{\circ} \mathrm{C}$ 
for 12 hours. The crude reaction mixture was filtered through a plug of silica gel with $100 \%$ DCM as the eluent to afford a pale yellow filtrate. The solvent was removed in vacuo and the solid was triturated twice with $50 \mathrm{~mL}$ hexanes, followed by removal of the hexanes in vacuo, affording 5,5'(mesitylmethylene)bis(2-trityl-1H-pyrrole) $(10.5 \mathrm{~g}, 96 \%)$ as a yellow powder. ${ }^{1} \mathbf{H}$ NMR (600 $\mathrm{MHz}, \mathrm{CDCl}_{3}$ ): $\delta / \mathrm{ppm} 7.35$ (br, s, $\left.2 \mathrm{H}\right)$ 7.20-7.23 (m, 17 H), 7.09-7.10 (m, $\left.13 \mathrm{H}\right), 6.67$ (s, $2 \mathrm{H}$ ), $5.86(\mathrm{t}, J=3.10 \mathrm{~Hz}, 2 \mathrm{H}), 5.72-5.73(\mathrm{~m}, 3 \mathrm{H}), 2.20(\mathrm{~s}, 3 \mathrm{H}), 1.90(\mathrm{~s}, 6 \mathrm{H}) .{ }^{13} \mathbf{C}\left\{{ }^{1} \mathbf{H}\right\} \mathbf{N M R}(125$ $\left.\mathrm{MHz}, \mathrm{CDCl}_{3}\right): \delta / \mathrm{ppm} 146.21,137.12 .136 .20,135.19,134.42,131.08,130.32,127.69,126.44$, 110.62, 105.54, 60.52, 38.54, 20.84, 20.69. HRMS $\left(\mathrm{ESI}^{+}\right) \mathrm{m} / z$ Calc. $749.3890\left[\mathrm{C}_{56} \mathrm{H}_{48} \mathrm{~N}_{2}+\mathrm{H}\right]^{+}$, Found. $749.3820[\mathrm{M}+\mathrm{H}]^{+}$.
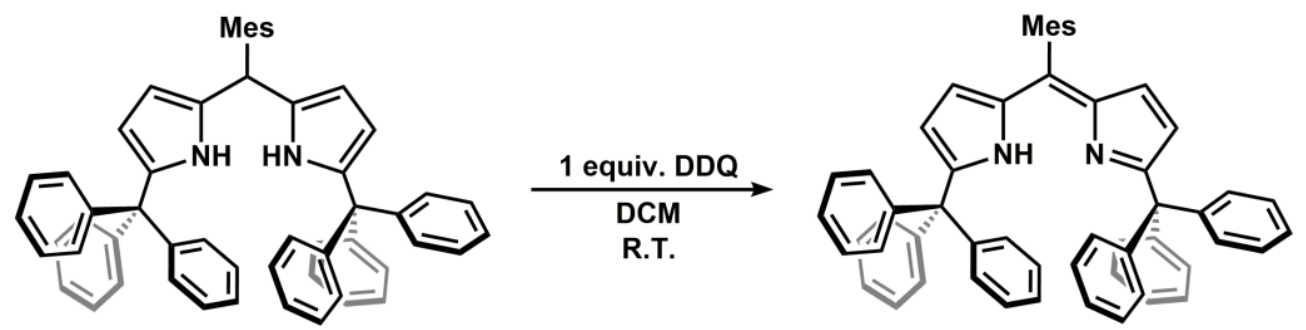

(Z)-2-(mesityl(5-trityl-2H-pyrrol-2-ylidene)methyl)-5-trityl-1H-pyrrole $\left({ }^{\operatorname{Tr}} \mathrm{L}\right) \mathrm{H}:$ An ovendried $500 \mathrm{~mL}$ round-bottom flask was charged with 5,5'-(mesitylmethylene)bis(2-trityl- $1 \mathrm{H}$ pyrrole) (10.5 g, $14.0 \mathrm{mmol}, 1$ equiv) in $200 \mathrm{~mL}$ DCM. To a stirring solution, 2,3-dichloro-5,6dicyanoquinone (DDQ) (3.18 g, $14.0 \mathrm{mmol}, 1$ equiv) was added to yield a dark orange solution. After stirring for 5 hours at room temperature, the reaction mixture was concentrated in vacuo and filtered through a plug of neutral alumina with $100 \%$ DCM as the eluent. The filtrate was concentrated in vacuo and washed with acetonitrile $(2 \times 50 \mathrm{~mL})$ to afford $\left({ }^{\operatorname{Tr}} \mathbf{L}\right) \mathbf{H}(9.37 \mathrm{~g}, 86 \%)$ as a yellow powder. ${ }^{1} \mathbf{H}$ NMR $\left(600 \mathrm{MHz}, \mathrm{CDCl}_{3}\right): \delta / \mathrm{ppm} 11.5(\mathrm{~s}, 1 \mathrm{H}) 7.06-7.11(\mathrm{~m}, 30 \mathrm{H}), 6.88(\mathrm{~s}$, $2 \mathrm{H}), 6.14(\mathrm{~d}, J=4.14 \mathrm{~Hz}, 2 \mathrm{H}), 5.98(\mathrm{~d}, J=4.21 \mathrm{~Hz}, 2 \mathrm{H}), 2.32(\mathrm{~s}, 3 \mathrm{H}), 2.10(\mathrm{~s}, 6 \mathrm{H}) .{ }^{13} \mathbf{C}\left\{{ }^{1} \mathbf{H}\right\}$ NMR (125 MHz, $\left.\mathrm{CDCl}_{3}\right): \delta / p p m ~ 161.21,145.78,140.67,137.95,137.19$ 136.98, 134.06, 130.48, 127.73, 126.14, 125.77, 120.68, 62.27, 21.27, 20.15. HRMS $\left(\mathrm{ESI}^{+}\right) \mathrm{m} / \mathrm{z}$ Calc. 747.3734 $\left[\mathrm{C}_{56} \mathrm{H}_{46} \mathrm{~N}_{2}+\mathrm{H}\right]^{+}$, Found. $747.3730[\mathrm{M}+\mathrm{H}]^{+}$. 


\section{Metal Complex Synthesis.}

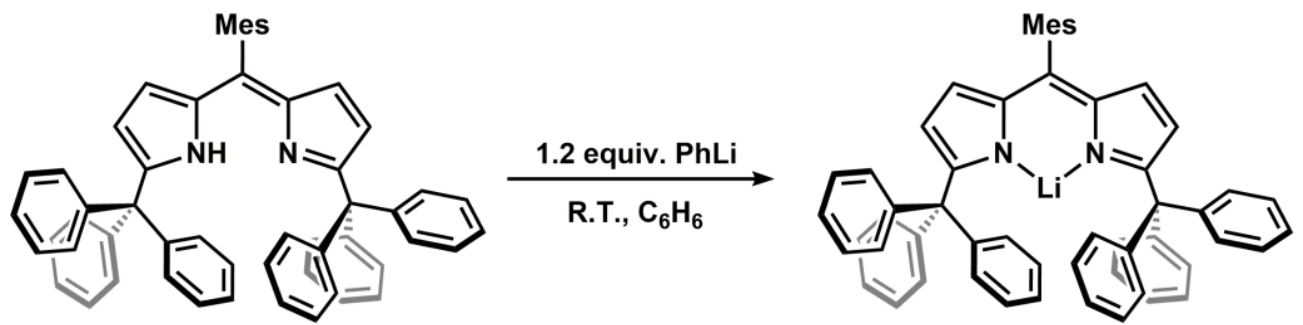

$\left({ }^{\mathrm{Tr}} \mathbf{L}\right) \mathbf{L i}$ : In an oven-dried $20 \mathrm{~mL}$ vial, $\left({ }^{\mathrm{Tr}} \mathrm{L}\right) \mathrm{H}(0.5 \mathrm{~g}, 0.67 \mathrm{mmol}, 1$ equiv) and PhLi (0.068 g, 0.80 mmol, 1.2 equiv) were dissolved in $10 \mathrm{~mL}$ benzene and stirred for 15 hours at room temperature. The dark orange mixture was filtered through a coarse glass frit with Celite to remove excess PhLi. The Celite was washed with an additional $20 \mathrm{~mL}$ benzene. The collected filtrate was frozen and benzene was removed by sublimation in vacuo to afford $\left({ }^{\mathrm{Tr}} \mathbf{L}\right) \mathbf{L i}$ as an orange powder $(0.47 \mathrm{~g}$, 93\%). ${ }^{1} \mathbf{H}$ NMR (600 MHz, $\left.\mathrm{C}_{6} \mathrm{D}_{6}\right):$ : $/ \mathrm{ppm} 7.31-7.33$ (m, $\left.12 \mathrm{H}\right), 7.17$ (s, $\left.1 \mathrm{H}\right), 6.92-6.95$ (m, 12 H), 6.86-6.89 (m, $6 \mathrm{H}), 6.82(\mathrm{~s}, 2 \mathrm{H}), 6.75(\mathrm{~d}, J=4.28 \mathrm{~Hz}, 2 \mathrm{H}), 6.39(\mathrm{~d}, J=3.98 \mathrm{~Hz}, 2 \mathrm{H}), 2.35$ (s, $6 \mathrm{H}), 2.19$ (s, $\left.3 \mathrm{H}) .{ }^{13} \mathbf{C}_{\{}{ }^{1} \mathbf{H}\right\}$ NMR (125 MHz, $\left.\mathrm{C}_{6} \mathrm{D}_{6}\right)$ : $\delta / \mathrm{ppm} 166.50,148.31,147.66,141.12$, 137.92, 136.98, 136.57, 130.66, 130.50, 128.28, 127.96, 126.61, 119.78, 63.67, 21.26, 20.51.
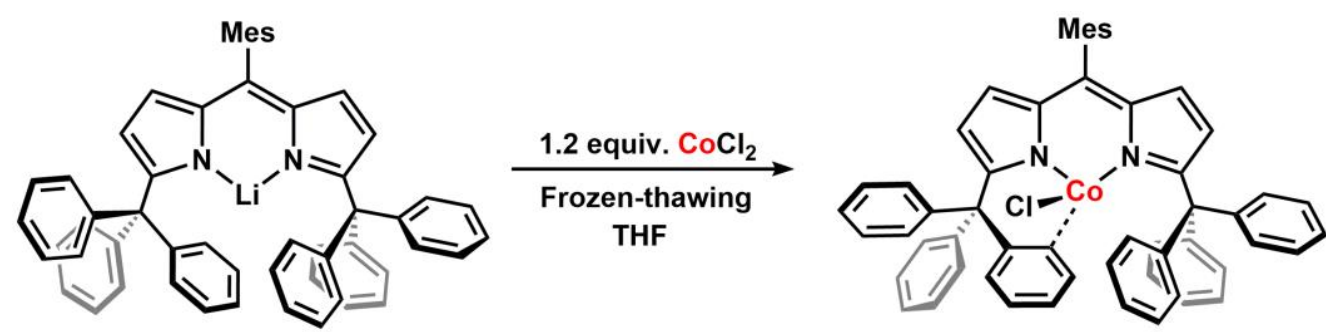

( $\left.{ }^{\operatorname{Tr}} \mathbf{L}\right) \mathbf{C o C l}, 1$ : In an oven-dried $20 \mathrm{~mL}$ vial, anhydrous $\mathrm{CoCl}_{2}(0.105 \mathrm{~g}, 0.81 \mathrm{mmol}, 1.2$ equiv) was dissolved in THF and frozen in a liquid nitrogen cooled cold-well. To a frozen solution, a solution of ( $\left.{ }^{\mathrm{Tr}} \mathrm{L}\right) \mathrm{Li}(0.52 \mathrm{~g}, 0.68 \mathrm{mmol}, 1$ equiv) in THF was added and stirred for 20 hours at room temperature. The resulting dark red reaction mixture was filtered through a coarse glass frit with Celite to remove $\mathrm{LiCl}$ and the excess $\mathrm{CoCl}_{2}$. The Celite was washed with an additional $20 \mathrm{~mL}$ benzene. The collected filtrate was frozen and benzene was removed by sublimation in vacuo to afford $\left({ }^{\mathrm{Tr}} \mathbf{L}\right) \mathbf{C o C l}$ as a dark red powder $(0.52 \mathrm{~g}, 90 \%)$. Crystals suitable for X-ray diffraction were grown from a 2:1 $n$-hexane/benzene mixture at room temperature. ${ }^{1} \mathbf{H} \mathbf{~ N M R}(600 \mathrm{MHz}, 295 \mathrm{~K}$, 
$\left.\mathrm{C}_{6} \mathrm{D}_{6}\right): \delta / \mathrm{ppm} 68.14,23.15,20.56,4.70,0.64,-1.16,-10.13,-37.86$. Anal. Calc. for $\mathrm{C}_{56} \mathrm{H}_{45} \mathrm{ClCoN}_{2}$ : C 80.04, H 5.40, N 3.33; Found: C 80.00, H 5.29, N 3.45.
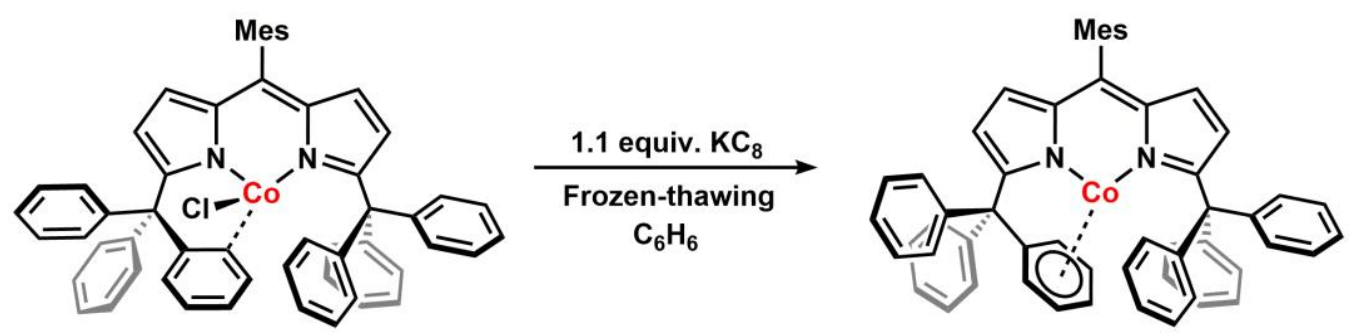

( $\left.{ }^{\operatorname{Tr}} \mathbf{L}\right) \mathbf{C o}$, 2: In an oven-dried $20 \mathrm{~mL}$ vial, $\left({ }^{\operatorname{Tr}} \mathbf{L}\right) \mathbf{C o C l}(0.4 \mathrm{~g}, 0.476 \mathrm{mmol}, 1$ equiv) was dissolved in $10 \mathrm{~mL}$ of benzene and added to a frozen solution of potassium graphite $\left(\mathrm{KC}_{8}, 0.071 \mathrm{~g}, 0.524\right.$ mmol, 1.1 equiv). The reaction mixture was slowly warmed up to room temperature and stirred for 3 hours at room temperature. The dark red-orange mixture was filtered through a coarse glass frit with Celite to remove graphite. The Celite was washed with an additional $20 \mathrm{~mL}$ benzene. The collected filtrate was frozen and benzene was removed by sublimation in vacuo to afford ( $\left.{ }^{\operatorname{Tr}} \mathbf{L}\right) \mathbf{C o}$ as a dark orange powder. $(0.3 \mathrm{~g}, 78 \%)$. Crystals suitable for X-ray diffraction were grown from a 1:1 $n$-hexane/benzene mixture at room temperature. ${ }^{1} \mathbf{H} \mathbf{~ N M R}\left(600 \mathrm{MHz}, 295 \mathrm{~K}, \mathrm{C}_{6} \mathrm{D}_{6}\right): \delta / \mathrm{ppm}$ 49.82, 21.04, 14.90, 5.84, 5.16, 4.54, 0.96, -2.51. Anal. Calc. for $\mathrm{C}_{56} \mathrm{H}_{45} \mathrm{CoN}_{2}$ : C 83.56, H 5.64, N 3.48; Found: C 83.45, H 5.50, N 3.39.
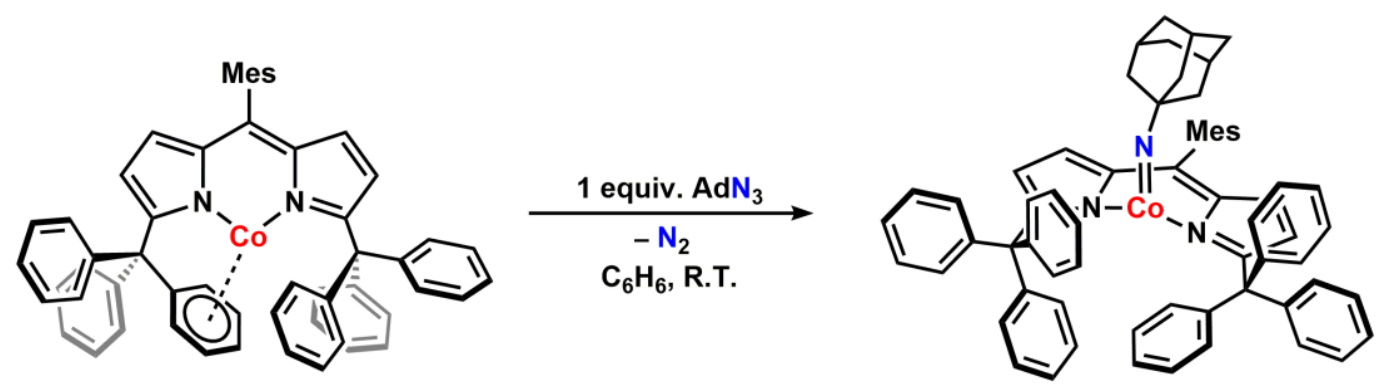

( $\left.{ }^{\operatorname{Tr}} \mathbf{L}\right) \mathbf{C o}(\mathbf{N A d})$, 3: $\mathrm{In}$ an oven-dried $20 \mathrm{~mL}$ vial, a solution of 1-azidoadamantane (22 $\mathrm{mg}, 0.12$ mmol, 1.0 equiv.) in benzene was added to a stirring solution of ( $\left.{ }^{\operatorname{Tr}} \mathbf{L}\right) \mathbf{C o}(100 \mathrm{mg}, 0.12 \mathrm{mmol}, 1.0$ equiv) in benzene to observe an immediate color change from dark red to dark purple. After stirring for $30 \mathrm{~min}$ at room temperature, the reaction mixture was frozen and benzene was removed by sublimation in vacuo to afford ( $\left.{ }^{\operatorname{Tr}} \mathbf{L}\right) \mathbf{C o}(\mathbf{N A d})$ as a purple powder $(109 \mathrm{mg}, 92 \%)$. Crystals suitable 
for X-ray diffraction were grown from a 1:1 $n$-hexane/benzene mixture at room temperature. ${ }^{1} \mathbf{H}$

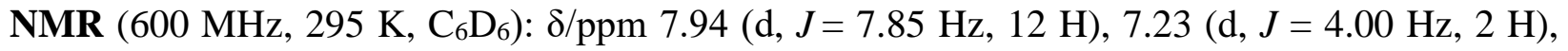
$6.97(\mathrm{t}, J=7.32 \mathrm{~Hz}, 6 \mathrm{H}), 6.84(\mathrm{~s}, 2 \mathrm{H}), 6.67(\mathrm{t}, J=7.75 \mathrm{~Hz}, 11 \mathrm{H}), 6.03(\mathrm{~d}, J=4.01 \mathrm{~Hz}, 2 \mathrm{H})$, 2.26 (s, $5 \mathrm{H}), 2.20$ (s, $3 \mathrm{H}), 1.80(\mathrm{~s}, 3 \mathrm{H}), 1.63(\mathrm{t}, J=14.93 \mathrm{~Hz}, 6 \mathrm{H}), 1.08(\mathrm{~s}, 6 \mathrm{H}) .{ }^{13} \mathbf{C}\left\{{ }^{1} \mathbf{H}\right\} \mathbf{N M R}$ (125 MHz, $\left.\mathrm{C}_{6} \mathrm{D}_{6}\right)$ : $\delta / \mathrm{ppm} 192.23,153.36,151.26,146.88,137.28,135.37,134.93,132.14,129.57$, 128.59, 125.51, 124.41, 69.27, 61.65, 61.12, 37.54, 33.30, 31.03, 21.25, 20.69. Anal. Calc. for $\mathrm{C}_{66} \mathrm{H}_{60} \mathrm{CoN}_{3}$ : C 83.08, H 6.34, N 4.40; Found: C 82.72, H 6.52, N 4.71.
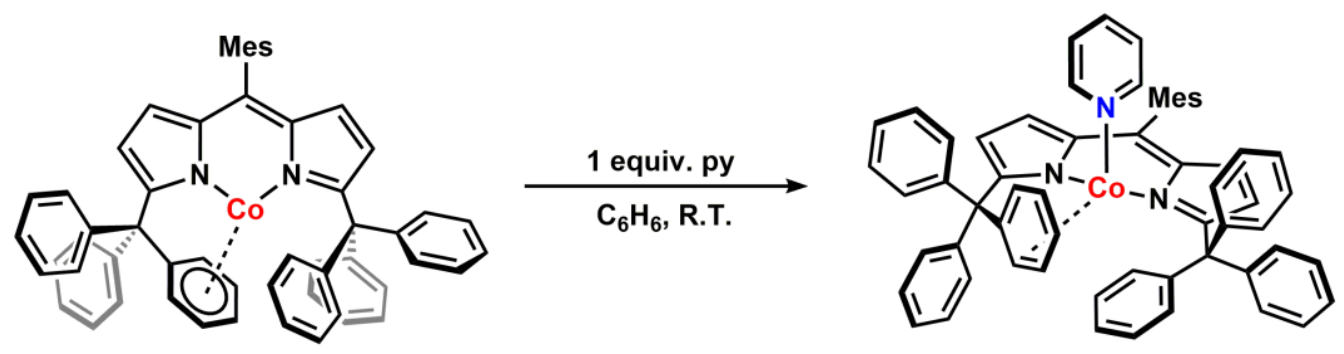

( $\left.{ }^{\operatorname{Tr}} \mathbf{L}\right) \mathbf{C o}(\mathbf{p y}), 4$ : In an oven-dried $20 \mathrm{~mL}$ vial, $\left({ }^{\operatorname{Tr}} \mathbf{L}\right) \mathbf{C o}(50 \mathrm{mg}, 0.062 \mathrm{mmol}, 1$ equiv) was dissolved in $3 \mathrm{~mL}$ of benzene and added to a diluted solution of pyridine $(5.4 \mathrm{mg}, 0.068 \mathrm{mmol}, 1.1$ equiv) in $2 \mathrm{~mL}$ benzene. The reaction mixture was stirred for $10 \mathrm{~min}$ at room temperature and benzene was removed by sublimation in vacuo to afford 4 as a dark brown powder. $(52.2 \mathrm{mg}, 95 \%)$. Crystals suitable for X-ray diffraction were grown from a 1:1 $n$-hexane/benzene mixture at room temperature. ${ }^{1} \mathbf{H}$ NMR $\left(600 \mathrm{MHz}, 295 \mathrm{~K}, \mathrm{C}_{6} \mathrm{D}_{6}\right): \delta / \mathrm{ppm}$ 68.11, 56.18, 8.47, 5.84, 6.51, 2.68, 1.33, -1.96. Anal. Calc. for $\mathrm{C}_{61} \mathrm{H}_{50} \mathrm{CoN}_{3}$ : C 82.88, H 5.70, N 4.75; Found: C 83.01, H 5.65, N 4.45. 
Organoazide Substrate Synthesis.

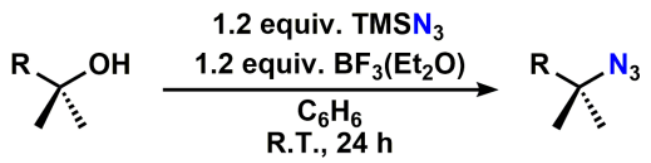

General Procedure: Boron trifluoride diethyl etherate (1.2 equiv) was added dropwise at $25{ }^{\circ} \mathrm{C}$ to a stirring solution of tertiary alcohol (15 mmol, 1 equiv) and trimethylsilyl azide (1.2 equiv) in benzene under $\mathrm{N}_{2}$. After 24 hours, the mixture was poured into water and extracted three times with $\mathrm{Et}_{2} \mathrm{O}$. The combined organic phases were washed with brine and dried over $\mathrm{MgSO}_{4}$, filtered and concentrated. The crude products were purified via silica gel chromatography (hexanes as an eluent) and stored over molecular sieves for further uses. ${ }^{3}$

\section{(4-azido-4-methylpentyl)benzene:}<smiles>CC(C)(N)CCCc1ccccc1</smiles>

Synthesized following previously reported procedure. ${ }^{4}$ Spectral data were consistent with previously reported characterization of the product. ${ }^{4}$

\section{(4-azido-4-methylpentyl-1,1- $\left.d_{2}\right)$ benzene:}

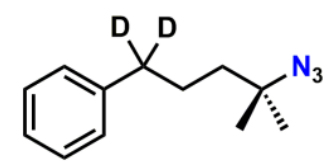

Synthesized following previously reported procedure. ${ }^{4}$ Spectral data were consistent with previously reported characterization of the product. ${ }^{4}$

(4-azido-4-methylpentyl-1- $d$ )benzene:<smiles>[2H]C(CCC(C)(C)N)c1ccccc1</smiles>

Synthesized following previously reported procedure. ${ }^{4}$ Spectral data were consistent with previously reported characterization of the product. ${ }^{4}$ 


\section{(4-azido-4-methylpentyl-1,1- $\left.d_{2}\right)$ benzene:}<smiles>Cc1ccc(CCCC(C)(C)N)cc1</smiles>

Synthesized following previously reported procedure. ${ }^{4}$ Spectral data were consistent with previously reported characterization of the product. ${ }^{4}$

\section{(4-azido-4-methylpentyl-1,1- $\left.d_{2}\right)$ benzene:}<smiles>COc1ccc(CCCC(C)(C)N)cc1</smiles>

Synthesized following previously reported procedure. ${ }^{4}$ Spectral data were consistent with previously reported characterization of the product. ${ }^{4}$

\section{1-(4-azido-4-methylpentyl)-4-(trifluoromethyl)benzene:}<smiles>CC(C)(N)CCCc1ccc(C(F)(F)F)cc1</smiles>

Synthesized following previously reported procedure. ${ }^{4}$ Spectral data were consistent with previously reported characterization of the product. ${ }^{4}$

\section{1-(4-azido-4-methylpentyl)-4-fluorobenzene:}
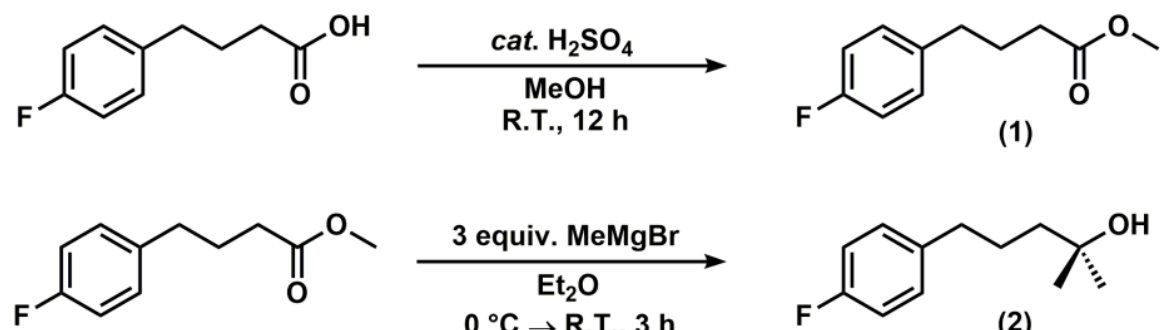<smiles>CC(C)(O)CCCc1ccc(F)cc1</smiles>

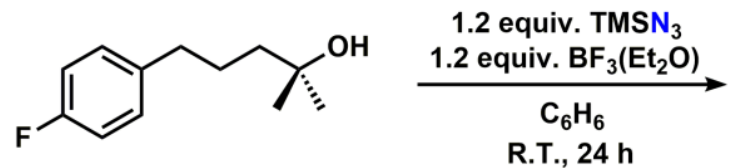<smiles>CC(C)(N)CCCc1ccc(F)cc1</smiles>

(1) methyl 4-(4-fluorophenyl)butanoate: Catalytic amount of $\mathrm{H}_{2} \mathrm{SO}_{4}$ (concentrated) was added to a solution of 4-phenylbutanoic acid (1 equiv) in $50 \mathrm{~mL}$ methanol. The reaction mixture was stirred at $25{ }^{\circ} \mathrm{C}$ for 12 hours. Upon completion, the reaction mixture was concentrated and diluted 
in $\mathrm{Et}_{2} \mathrm{O}$. The aqueous phase was extracted three times with $\mathrm{Et}_{2} \mathrm{O}$ and the combined organic phases were washed with brine, dried over $\mathrm{MgSO}_{4}$, filtered, and concentrated. The product was used without further purification. Spectral data were consistent with previously reported characterization of the product. ${ }^{5}$

(2) 5-(4-fluorophenyl)-2-methylpentan-2-ol: An oven-dried schlenk flask was charged with $3 \mathrm{~g}$ of methyl 4-(4-fluorophenyl)butanoate in dry $\mathrm{Et}_{2} \mathrm{O}$ and placed under $\mathrm{N}_{2}$. The solution was cooled in an ice-bath and a diethyl ether solution of methyl magnesium bromide (3 equiv) was added slowly at $0{ }^{\circ} \mathrm{C}$. The reaction mixture was stirred at room temperature for 3 hours. After that, the reaction mixture was quenched with a saturated aqueous solution of $\mathrm{NH}_{4} \mathrm{Cl}$ and diluted with water. The aqueous phase was extracted three times with diethyl ether. The combined organic phases were washed with brine, dried over $\mathrm{Na}_{2} \mathrm{SO}_{4}$, filtered, and concentrated. Quantitative yield. The product was used without further purification. ${ }^{1} \mathbf{H} \mathbf{~ N M R}\left(600 \mathrm{MHz}, \mathrm{CDCl}_{3}\right) \delta / \mathrm{ppm}$ : 7.11-7.15 (m, $2 \mathrm{H}), 6.94-6.98$ (m, 2 H), 2.59 (t, J = 7.68 Hz, $2 \mathrm{H}), 1.64-1.70$ (m, $2 \mathrm{H}), 1.48-1.50$ (m, $2 \mathrm{H}), 1.20$ (s, $6 \mathrm{H}) .{ }^{13} \mathrm{C}\left\{{ }^{1} \mathbf{H}\right\}$ NMR $\left(125 \mathrm{MHz}, \mathrm{CDCl}_{3}\right) \delta / \mathrm{ppm}: 162.31,160.37\left(\mathrm{~d}, J_{\mathrm{C}-\mathrm{F}}=121.5 \mathrm{~Hz}\right), 138.11$, 129.83, $129.77\left(\mathrm{~d}, J_{\mathrm{C}-\mathrm{F}}=3.83 \mathrm{~Hz}\right), 115.21,115.05\left(\mathrm{~d}, J_{\mathrm{C}-\mathrm{F}}=10.5 \mathrm{~Hz}\right), 71.02,43.46,35.62,29.42$, 26.49. HRMS $\left(\mathrm{ESI}^{+}\right) \mathrm{m} / z$ Calc. 219.1156 $\left[\mathrm{C}_{12} \mathrm{H}_{17} \mathrm{FO}+\mathrm{Na}\right]^{+}$, Found. $219.1153[\mathrm{M}+\mathrm{Na}]^{+}$.

(3) 1-(4-azido-4-methylpentyl)-4-fluorobenzene: Synthesized following General Procedure. ${ }^{\mathbf{1}} \mathbf{H}$

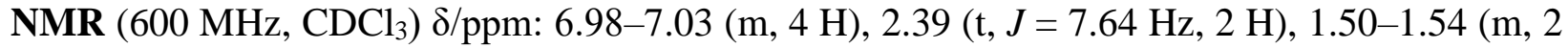
H), 1.23-1.26 (m, $2 \mathrm{H}), 0.90$ (s, $6 \mathrm{H}) .{ }^{13} \mathbf{C}\left\{{ }^{1} \mathbf{H}\right\}$ NMR (125 MHz, $\left.\mathrm{CDCl}_{3}\right) \delta / \mathrm{ppm}: 162.39,160.46$ $\left(\mathrm{d}, J_{\mathrm{C}-\mathrm{F}}=121.7 \mathrm{~Hz}\right), 137.75,129.82,129.76\left(\mathrm{~d}, J_{\mathrm{C}-\mathrm{F}}=3.83 \mathrm{~Hz}\right), 115.31,115.15\left(\mathrm{~d}, J_{\mathrm{C}-\mathrm{F}}=10.5\right.$ $\mathrm{Hz}), 61.64,41.07,35.33,26.34,26.15$. HRMS $\left(\mathrm{ESI}^{+}\right) \mathrm{m} / z$ Calc. $239.1667\left[\mathrm{C}_{12} \mathrm{H}_{16} \mathrm{FN}_{3}+\mathrm{NH}_{4}\right]^{+}$, Found. 239.1665 [M+NH$]^{+}$.

\section{2-azido-2,5-dimethylhexane:}

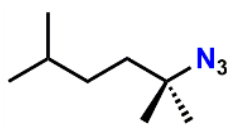

Synthesized following previously reported procedure. ${ }^{4}$ Spectral data were consistent with previously reported characterization of the product. ${ }^{4}$ 


\section{2-azido-2-methylhexane:}

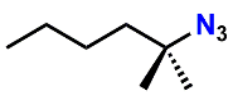

Synthesized following previously reported procedure. ${ }^{4}$ Spectral data were consistent with previously reported characterization of the product. ${ }^{4}$

\section{1-azido-1-butylcyclohexane:}

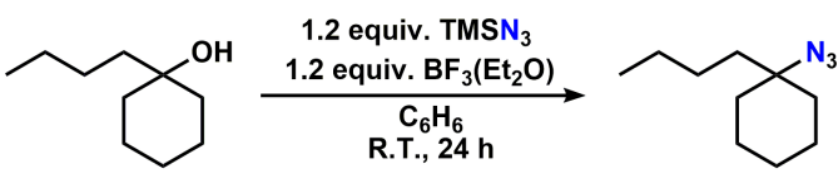

Synthesized following General Procedure. Spectral data were consistent with previously reported characterization of the product. ${ }^{6}$

\section{2-azido-2,5-dimethylhexane:}

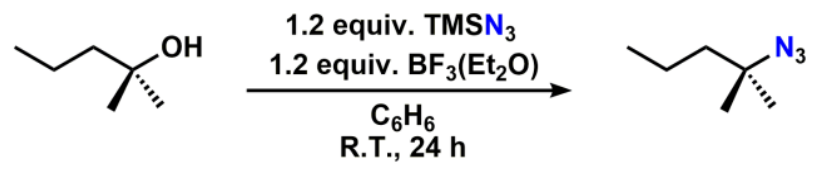

Synthesized following General Procedure. Spectral data were consistent with previously reported characterization of the product. ${ }^{3}$ 


\section{Mechanistic Studies.}

General consideration for kinetic experiments. All kinetic experiments were run in J. Young NMR tubes at the noted temperature. Stock solutions of $\left({ }^{\operatorname{Tr}} \mathrm{L}\right) \mathrm{Co}(\mathbf{2})$, azide substrate 5, and pyridine- $d_{5}$ were prepared in benzene- $d_{6}$ and were added separately with a micro-syringe to the J. Young NMR tube. The reaction mixture was frozen prior to NMR analysis. The frozen reaction mixture was thawed and placed into a thermally stabilized NMR instrument. In case of initial rate kinetic analysis, reactions were monitored to less than $10 \%$ of product (2,2-dimethyl-5phenylpyrrolidine) (6) formation. ${ }^{1} \mathrm{H}$ NMR data collection was done by using the array command, collecting spectra every 15 or 30 seconds. The resulting data points were analyzed using the initial rate method assuming the concentration of the cobalt imide $\mathbf{7}$ is consistent during early stages of the catalytic reactions. Each experiment was conducted in triplicate and average rates are reported with error bars corresponding to standard errors of those three experiments. 1,3,5trimethoxybenzene was used as internal standard for ${ }^{1} \mathrm{H}$ NMR integration. 
A. Reaction progression. A full reaction progression was monitored by ${ }^{1} \mathrm{H}$ NMR spectroscopy at $25{ }^{\circ} \mathrm{C}$ in benzene- $d_{6} .[2]=8.50 \mathrm{mM}$ and $[5]=85.0 \mathrm{mM}$.

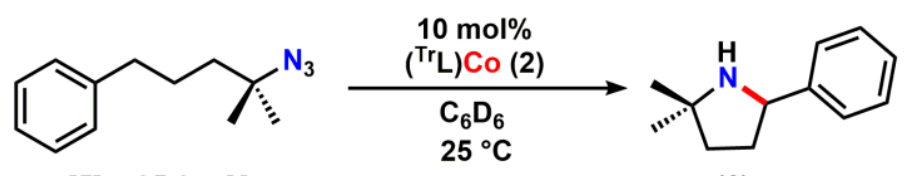

$[5]=85.0 \mathrm{mM}$

(6)
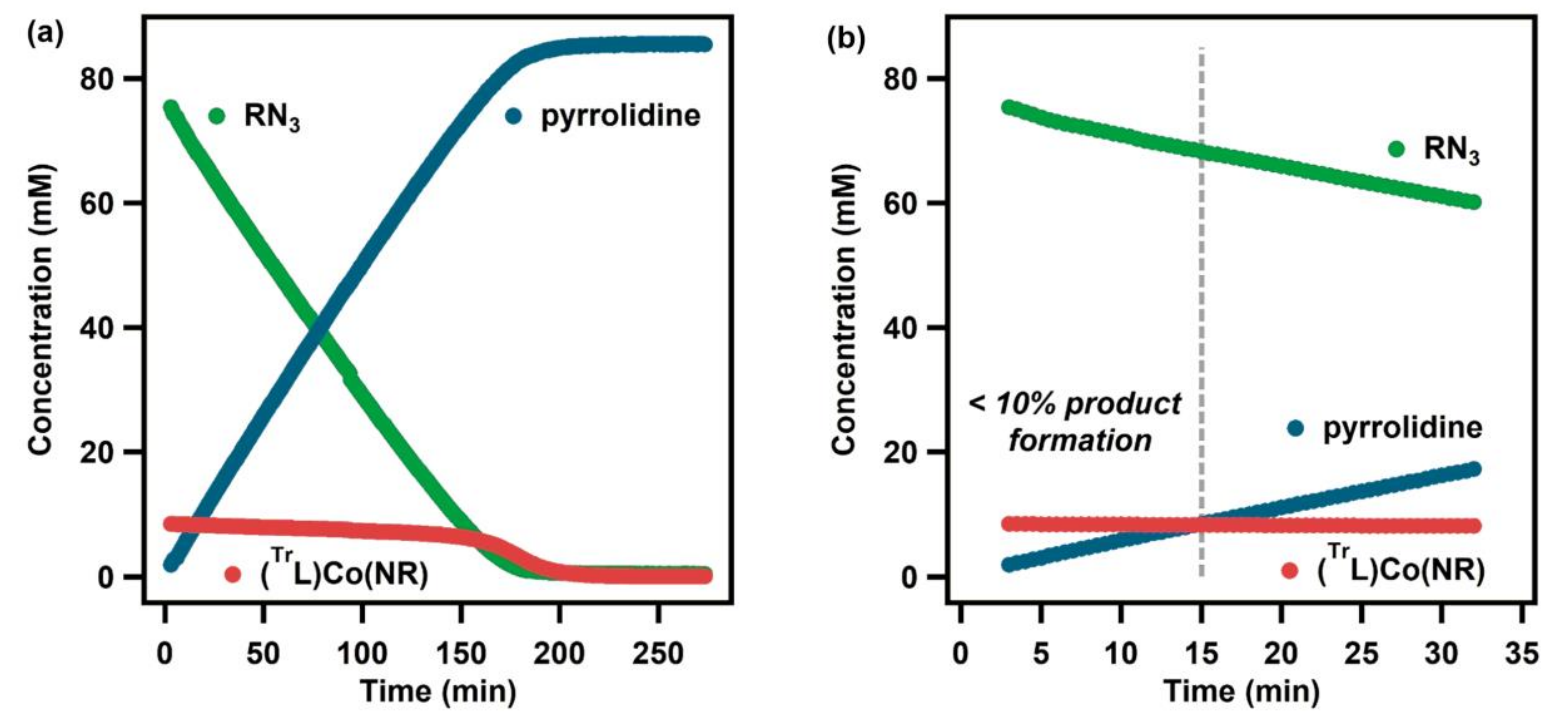

Figure S-1. Reaction progression. (a) Changes in concentration (mM) of each species over time until $>90 \%$ of the azide $\mathbf{5}$ consumed. (b) Early stages of the reaction: at early states of the reaction, concentration of imide $\mathbf{7}$ is constant as the concentration of azide $\mathbf{5}$ is sufficient to continuously oxidize catalyst $\mathbf{2}$ as soon as $\mathbf{7}$ generates product $\mathbf{6}$. Such observation is further supported by the fact that the following rates are almost identical.

$$
\begin{aligned}
\frac{d[6]}{d t} & =0.53(\mathrm{mM} / \mathrm{min}) \\
-\frac{d[5]}{d t} & =0.56(\mathrm{mM} / \mathrm{min})
\end{aligned}
$$




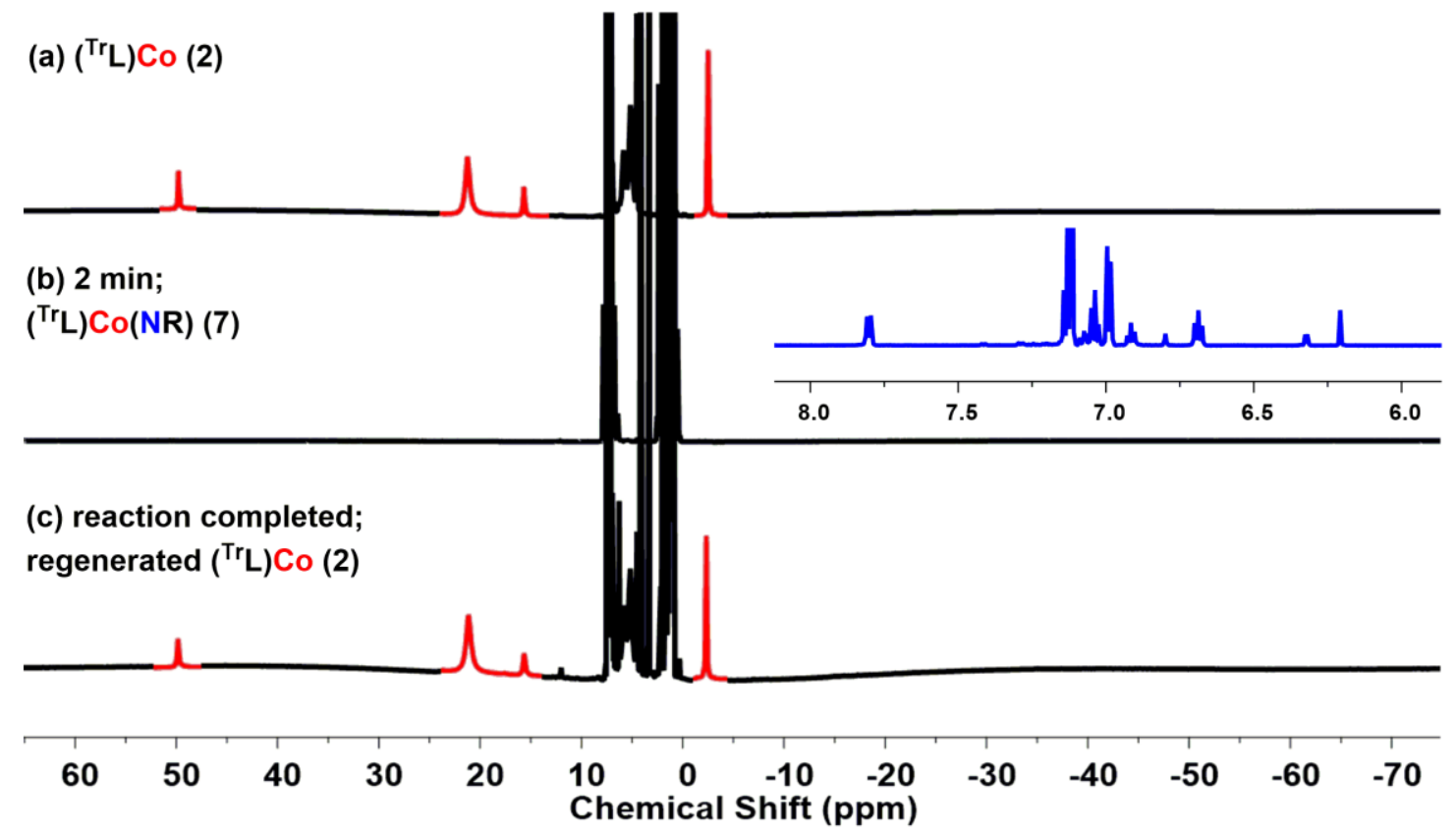

Figure S-2. Changes in ${ }^{1} \mathrm{H}$ NMR chemical shifts as the reaction proceeds. (a) ${ }^{1} \mathrm{H}$ NMR spectrum of $\left({ }^{\mathrm{Tr}} \mathrm{L}\right) \mathrm{Co} \mathbf{2}$ in benzene- $d_{6}$. (b) ${ }^{1} \mathrm{H}$ NMR spectrum following addition of 10 equiv of azide 5 in benzene- $d_{6}$. Peaks in diamagnetic region represent indicative peaks of the corresponding imido complex 7. (c) Regenerated 2 after the catalytic reaction is completed at $25^{\circ} \mathrm{C}$. 
(a) Authentic ( $\left.{ }^{\top r} L\right) C_{0}(2)$ in benzene- $d_{6}$

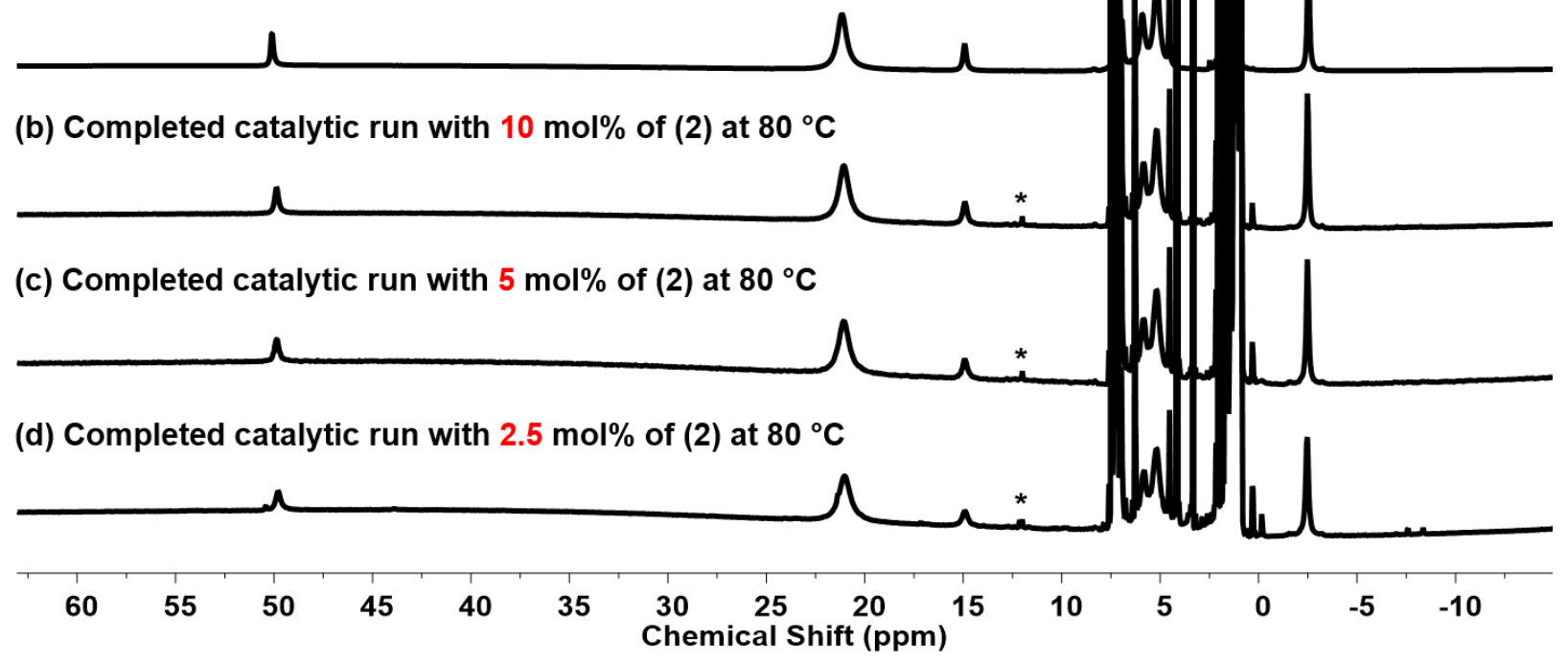

Figure S-3. Regenerated 2 after the catalytic reaction is completed at $80{ }^{\circ} \mathrm{C}$. (a) ${ }^{1} \mathrm{H}$ NMR spectrum of $\left({ }^{\mathrm{Tr}} \mathrm{L}\right) \mathrm{Co} 2$ in benzene- $d_{6}$. (b-d) ${ }^{1} \mathrm{H}$ NMR spectra of the reaction mixture after the reaction completed with 10, 20, and 40 equiv of azide 5, respectively, in benzene- $d_{6}$ at $80{ }^{\circ} \mathrm{C}$. Peak (*) at 12 ppm corresponds to the $\mathrm{N}-H$ peak of the free ligand $\left({ }^{\operatorname{Tr}} \mathrm{L}\right) \mathrm{H}$. 
B. Order in imido. The order in imide 7 was determined by initial rate kinetics with four different [2] and constant [5] $=85.0 \mathrm{mM}$ at $25^{\circ} \mathrm{C}$ in benzene- $d_{6}$.

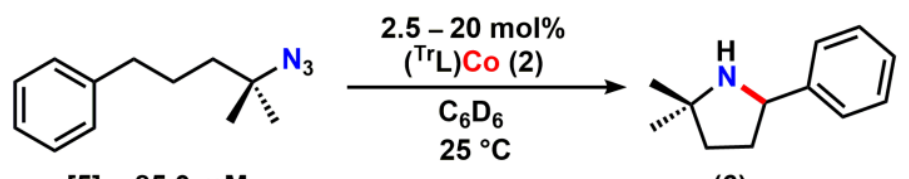

[5] $=85.0 \mathrm{mM}$

(6)

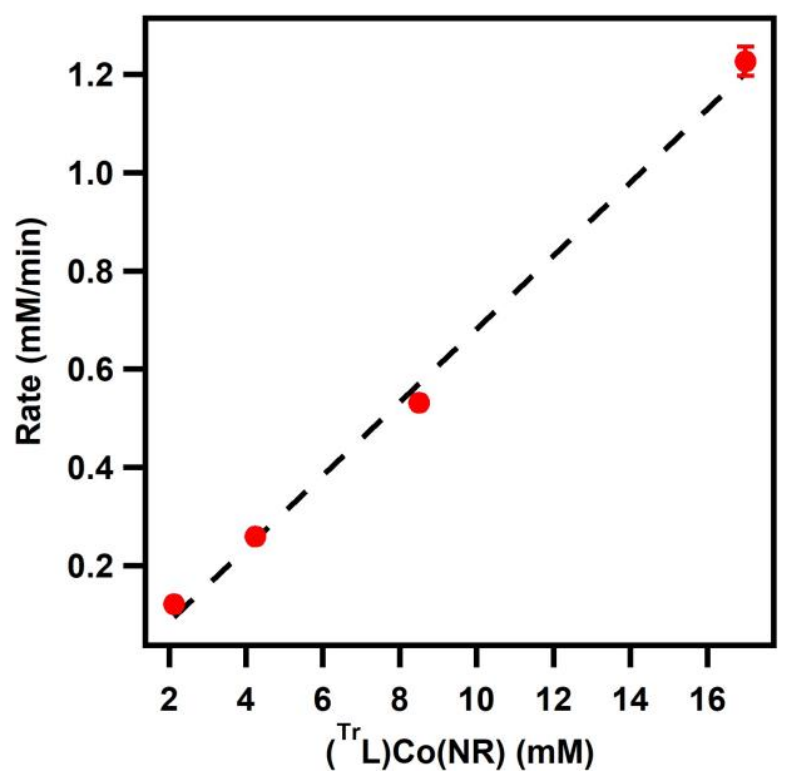

Figure S-4. Rate of formation of $\mathbf{6}(\mathrm{mM} / \mathrm{min})$ versus concentrations of imido $7(\mathrm{mM})$.

Table S-1. Averages and standard errors for the observed initial rates with varying concentrations of imido 7. The concentrations of imide 7 were calculated based on the initial amount of 2 assuming a quantitative conversion of 2 to 7 .

\begin{tabular}{c|ccc}
\hline Entry & (Tr $\mathrm{L}) \mathrm{Co}(\mathrm{mol} \%)$ & $\left.\left[{ }^{\mathrm{Tr}} \mathrm{L}\right) \mathrm{Co}(\mathrm{NR})\right]$ & Rate $(\mathrm{mM} / \mathrm{min})$ \\
\hline 1 & 2.5 & $2.13 \mathrm{mM}$ & $1.215(3) \times 10^{-1}$ \\
2 & 5.0 & $4.25 \mathrm{mM}$ & $2.59(7) \times 10^{-1}$ \\
3 & 10 & $8.50 \mathrm{mM}$ & $5.31(10) \times 10^{-1}$ \\
4 & 20 & $17.0 \mathrm{mM}$ & $1.23(3)$ \\
\hline
\end{tabular}


C. Order in azide substrate. The order in the azide substrate, (4-azido-4-methylpentyl)benzene (5) was determined by initial rate kinetics with four different [5] and constant [2] $=4.25 \mathrm{mM}$ at 25 ${ }^{\circ} \mathrm{C}$ in benzene- $d_{6}$.
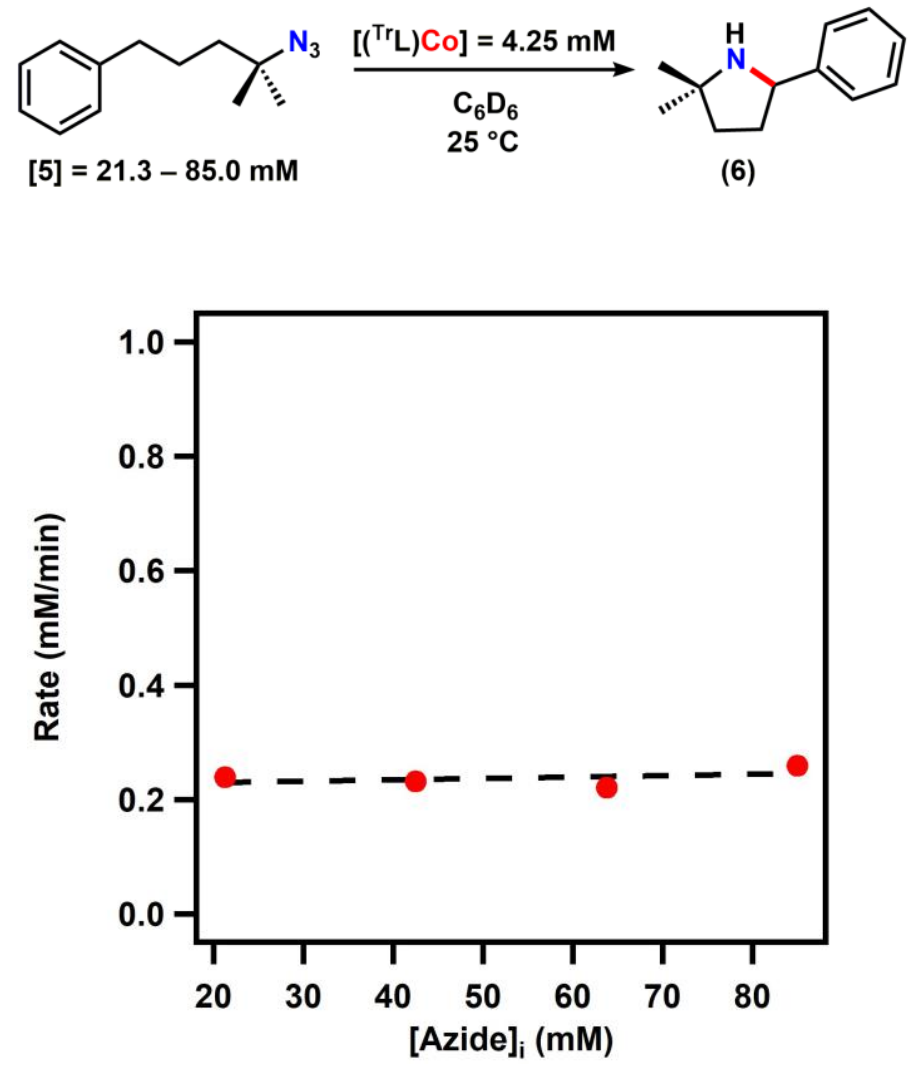

Figure S-5. Rate of formation of $\mathbf{6}(\mathrm{mM} / \mathrm{min})$ versus concentrations of azide $5(\mathrm{mM})$.

Table S-2. Averages and standard errors of the observed initial rates with varying concentrations of azide. [2] and [7] are the initial concentrations of the catalyst and the azide, respectively.

\begin{tabular}{c|ccc}
\hline Entry & {$\left[\left({ }^{\mathrm{Tr}} \mathrm{L}\right) \mathrm{Co}\right]$} & {$\left[\mathrm{RN}_{3}\right]$} & Rate $(\mathrm{mM} / \mathrm{min})$ \\
\hline 1 & $4.25 \mathrm{mM}$ & $21.3 \mathrm{mM}$ & $2.39(8) \times 10^{-1}$ \\
2 & $4.25 \mathrm{mM}$ & $42.5 \mathrm{mM}$ & $2.32(8) \times 10^{-1}$ \\
3 & $4.25 \mathrm{mM}$ & $63.8 \mathrm{mM}$ & $2.21(7) \times 10^{-1}$ \\
4 & $4.25 \mathrm{mM}$ & $85.0 \mathrm{mM}$ & $2.59(7) \times 10^{-1}$ \\
\hline
\end{tabular}




\section{Job analysis. ${ }^{7}$}
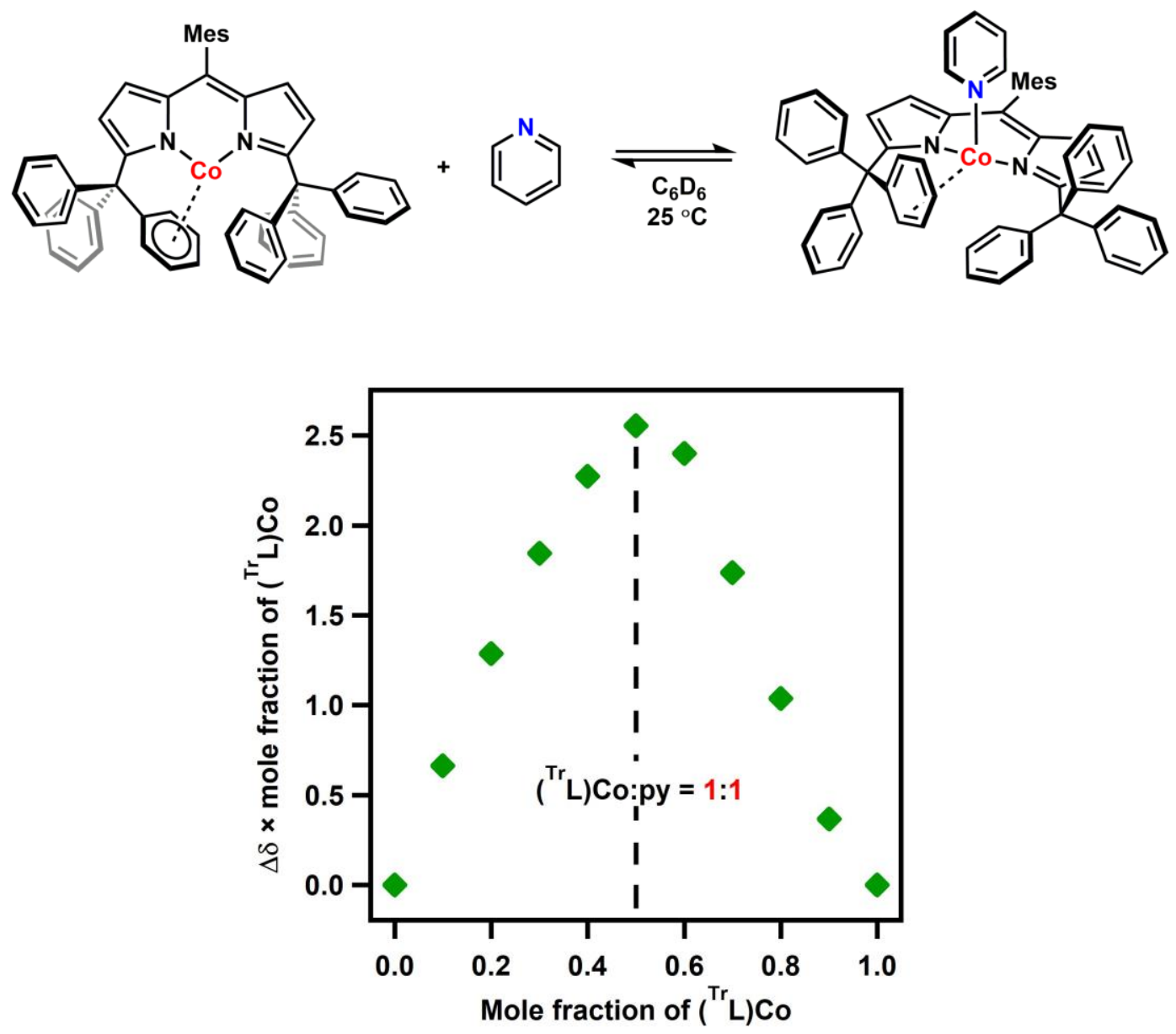

Figure S-6. Job plot obtained at $25^{\circ} \mathrm{C}$ in benzene- $d_{6}$ with [2] + [pyridine] $=8.85 \mathrm{mM}$. 
Table S-3. Chemical shifts (ppm) of 2 as a function of [pyridine] at $25{ }^{\circ} \mathrm{C}$ in benzene- $d_{6}$.

\begin{tabular}{c|ccc}
\hline Entry & {$\left[\left({ }^{\mathrm{Tr}} \mathrm{L}\right) \mathrm{Co}\right](\mathrm{mM})$} & {$[\mathrm{py}](\mathrm{mM})$} & Chemical shift (ppm) \\
\hline 1 & 8.85 & 0 & 49.84 \\
2 & 7.97 & 0.88 & 49.44 \\
3 & 7.08 & 1.77 & 48.55 \\
4 & 6.20 & 2.66 & 47.36 \\
5 & 5.31 & 3.54 & 45.84 \\
6 & 4.43 & 4.43 & 44.73 \\
7 & 3.54 & 5.31 & 44.16 \\
8 & 2.66 & 6.20 & 43.69 \\
9 & 1.77 & 7.08 & 43.41 \\
10 & 0.88 & 7.97 & 43.21 \\
\hline
\end{tabular}


E. Pyridine effect on reaction rates. The rate of formation of 6 as a function of [pyridine- $d_{5}$ ] was measured at $50{ }^{\circ} \mathrm{C}$ in benzene- $d_{6}$ with $[2]=8.50 \mathrm{mM},[5]=85.0 \mathrm{mM}$, and varying concentrations of pyridine- $d_{5}$.

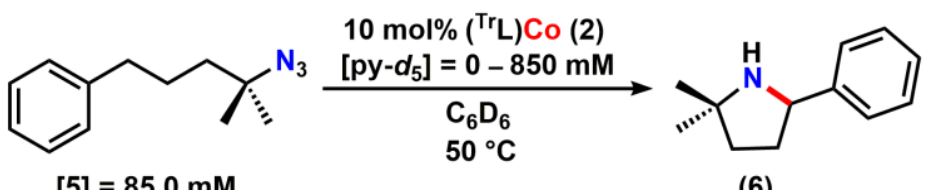

$[5]=85.0 \mathrm{mM}$

(6)

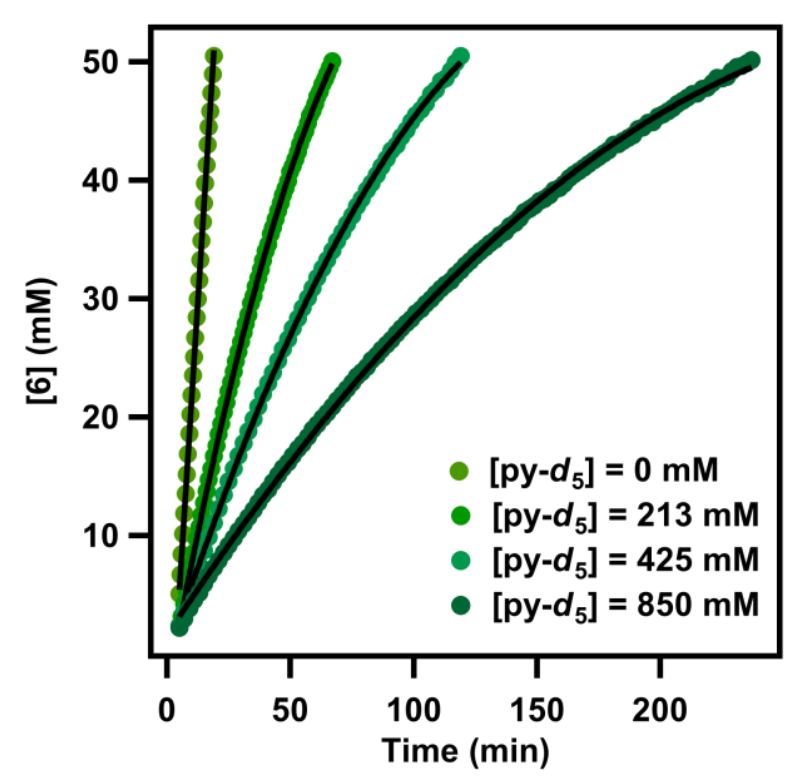

Figure S-7. Formation of 6 as a function of [pyridine- $d_{5}$ ]. Each reaction was monitored up to $>50 \%$ formation of the 6. Black lines represent fittings to a $3^{\text {rd }}$ polynomial, where $c_{0}, c_{1}, c_{2}$, and $c_{3}$ are constants, to obtain the overall rates at $30 \%$ formation of $6{ }^{8}$

$$
[6]=f(t)=c_{0}+c_{1} t+c_{2} t^{2}+c_{3} t^{3}
$$

The rate of formation of $\mathbf{5}$ was obtained from the derivative of $f(t)$ as following.

$$
\text { rate }=\frac{d[6]}{d t}=\frac{d f(t)}{d t}=c_{1}+2 c_{2} t+3 c_{3} t^{2}
$$


Table S-4. Averages and standard errors of the rates at $30 \%$ formation of $\mathbf{6}$ as a function of [pyridine- $d_{5}$ ].

\begin{tabular}{c|ccl}
\hline Entry & [pyridine- $d_{5}$ ] $(\mathrm{mM})$ & Rate $(\mathrm{mM} / \mathrm{min})$ & $\begin{array}{c}\text { Relative rates } \\
k_{\text {rel }}\end{array}$ \\
\hline 1 & 0 & $3.25(3)$ & 1.00 (def.) \\
2 & 213 & $1.33(11)$ & 0.41 \\
3 & 450 & $0.70(1)$ & 0.21 \\
4 & 850 & $0.35(1)$ & 0.11 \\
\hline
\end{tabular}

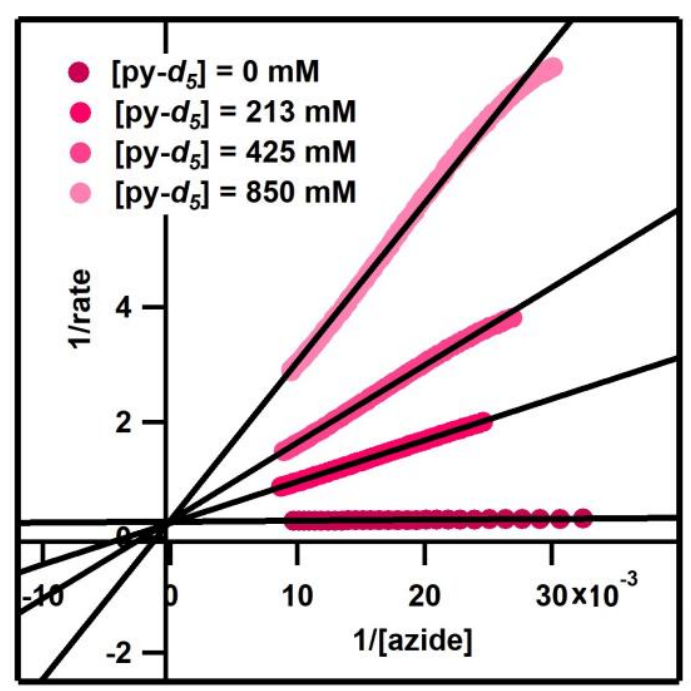

Figure S-8. Double-reciprocal plot at $50{ }^{\circ} \mathrm{C}$ in benzene- $d_{6}$. 


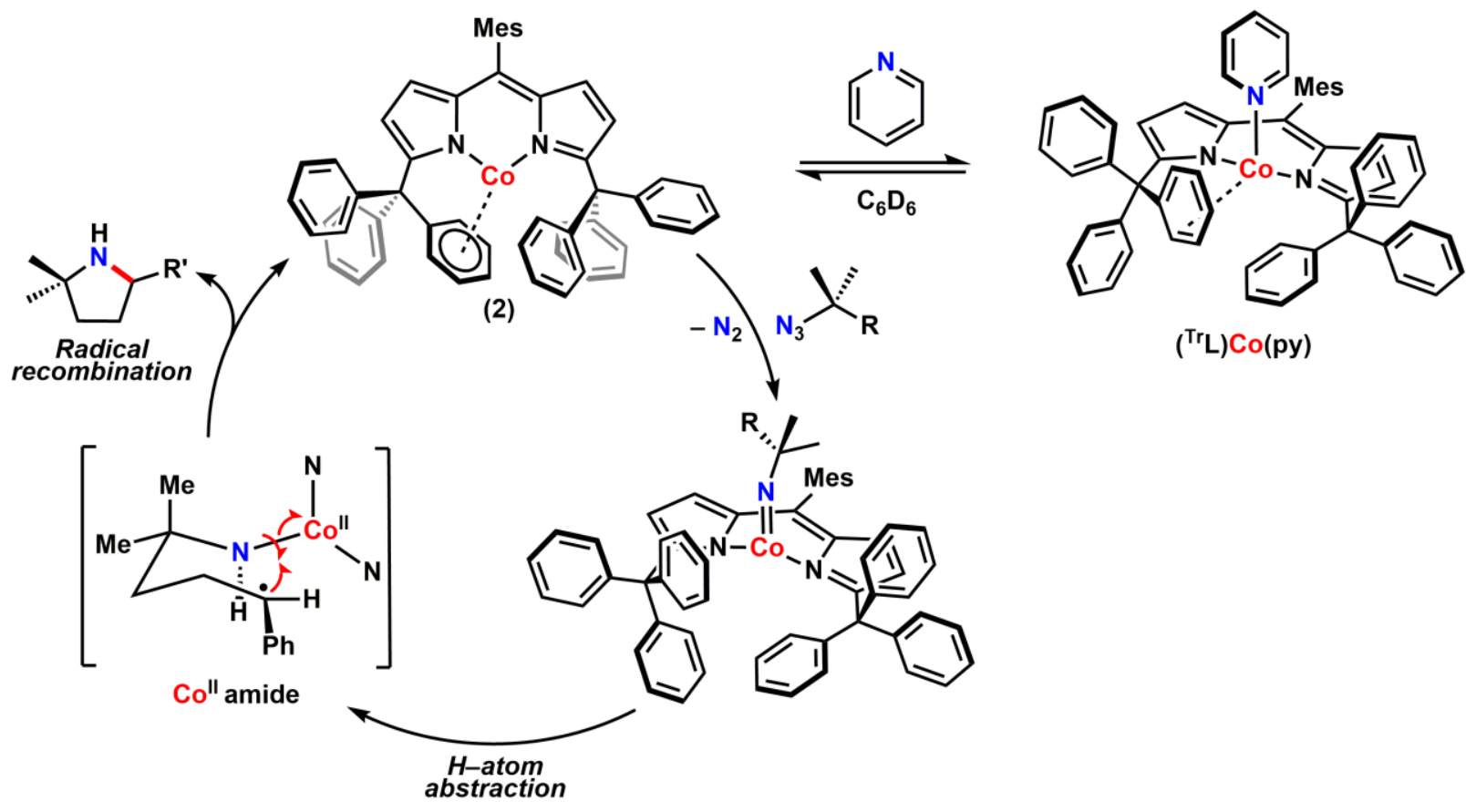

Figure S-9. Proposed catalytic cycle in the presence of pyridine. 


\section{F. Kinetic isotope effect (KIE) study.}

(A) The intermolecular KIE was determined by comparing the first order rate constants of the amination with $[2]=8.50 \mathrm{mM}$ and [azide $\left(\mathbf{5}\right.$ or $\left.\left.\mathbf{5}-\boldsymbol{d}_{2}\right)\right]=85.0 \mathrm{mM}$ at $25{ }^{\circ} \mathrm{C}$ in benzene- $d_{6}$. Initial rate kinetic analysis is adopted. For $k_{\mathrm{H}}$ see the values on Table S-1.

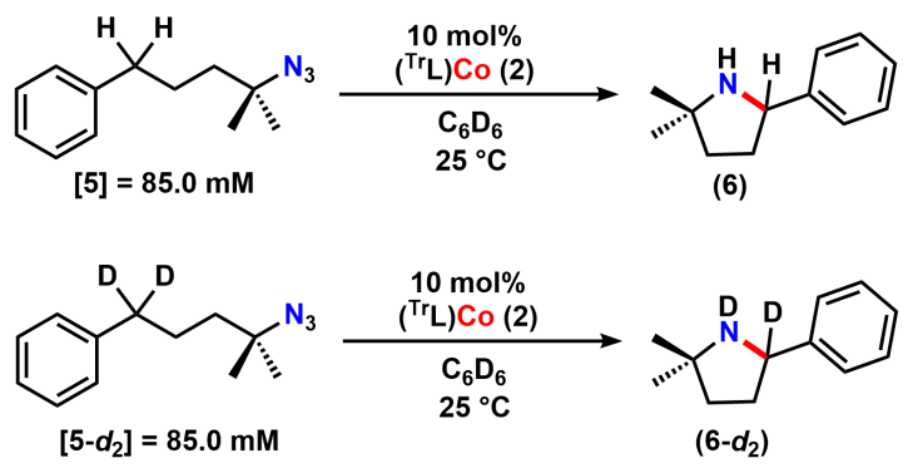

$$
\begin{gathered}
k_{\mathrm{H}}=6.3(1) \times 10^{-2}\left(\mathrm{~min}^{-1}\right) \\
k_{\mathrm{D}}=1.62(3) \times 10^{-3}\left(\mathrm{~min}^{-1}\right) \\
\mathrm{KIE}=k_{\mathrm{H}} / k_{\mathrm{D}}=38.4(1)
\end{gathered}
$$

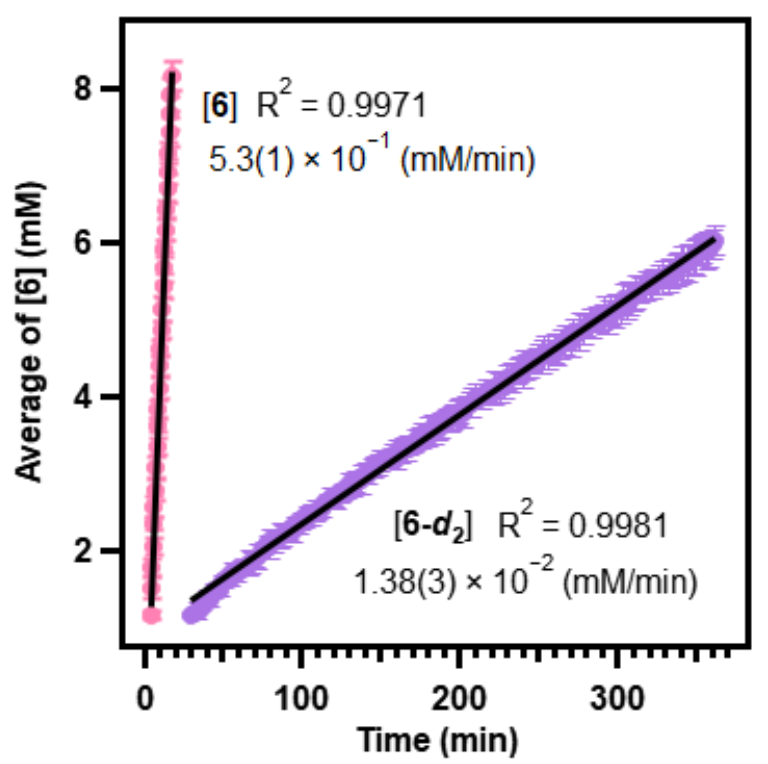

Figure S-10. Intermolecular KIE at $25^{\circ} \mathrm{C}$ in benzene- $d_{6}$. 
Table S-5. Averages and standard errors of the observed initial rates with $\mathbf{2}$ and azide 5-d .

\begin{tabular}{c|c}
\hline Entry & Rate $(\mathrm{mM} / \mathrm{min})$ \\
\hline Trial 1 & $1.33 \times 10^{-2}$ \\
Trial 2 & $1.45 \times 10^{-2}$ \\
Trial 3 & $1.37 \times 10^{-2}$ \\
Average & $1.38(3) \times 10^{-2}$ \\
\hline
\end{tabular}

(B) The intramolecular KIE value was determined by measuring the ratio between the $\mathrm{P}_{\mathrm{H}}$ and $\mathrm{P}_{\mathrm{D}}$ using ${ }^{1} \mathrm{H}$ NMR integration. [2] $=8.50 \mathrm{mM}$ and $\left[\mathbf{5}-\boldsymbol{d}_{\mathbf{1}}\right]=8.50 \mathrm{mM}$ at $25^{\circ} \mathrm{C}$ in benzene- $d_{6}$.

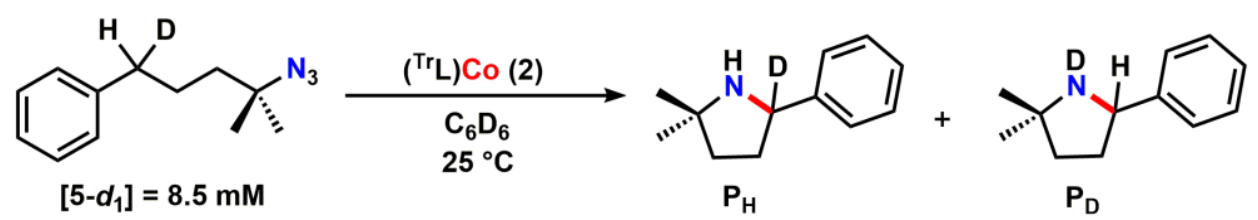

(a) Trial 1
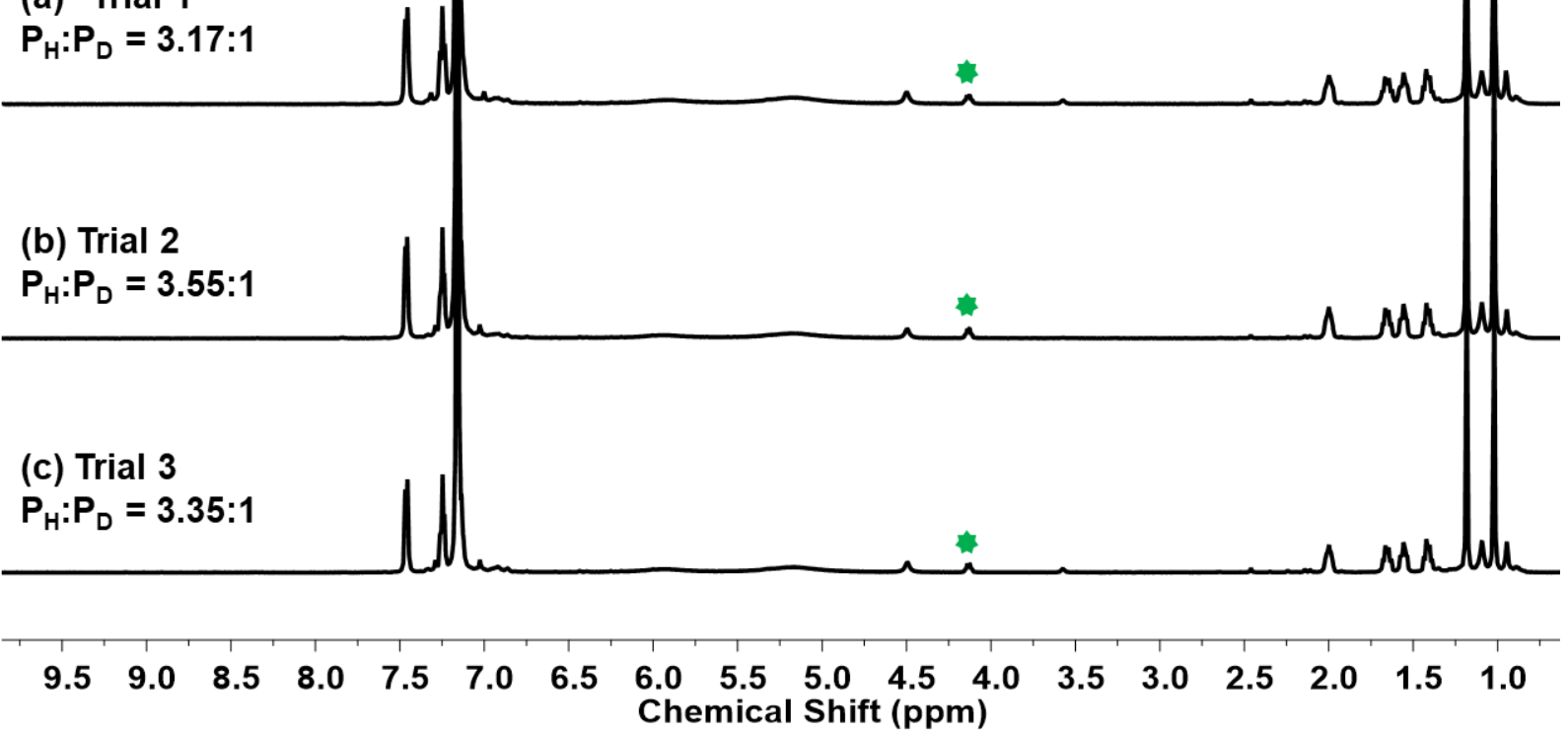

Figure S-11. ${ }^{1} \mathrm{H}$ NMR spectra showing the distribution of $\mathrm{P}_{\mathrm{H}}$ and $\mathrm{P}_{\mathrm{D}}$. The highlighted peak at 4.10 ppm corresponds to $\mathrm{P}_{\mathrm{D}}$ which was used for the quantification of each of the product. 


\section{Electrochemical Analysis.}

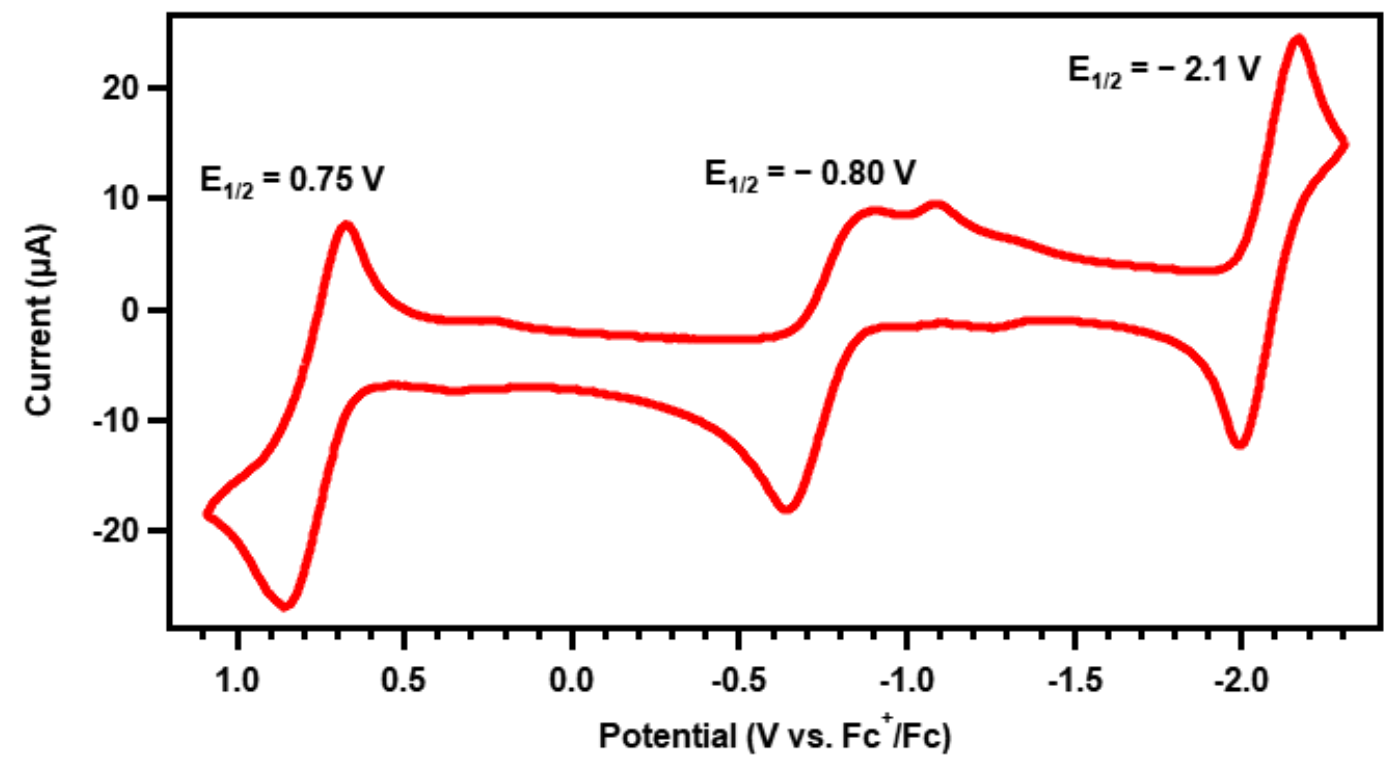

Figure S-12. Cyclic voltammogram of $\left({ }^{\mathrm{Tr}} \mathrm{L}\right) \mathrm{Co}$ (2) in 1,2-difluorobenzene using $0.1 \mathrm{M}$ $\left[{ }^{n} \mathrm{Bu}_{4} \mathrm{~N}\right]\left[\mathrm{PF}_{6}\right]$ as supporting electrolyte at room temperature; scan rate: $100 \mathrm{mV} / \mathrm{s}$, referenced to $\left[\mathrm{Cp}_{2} \mathrm{Fe}\right]^{+/ 0}$ couple. Open circuit potential $=-1.38 \mathrm{~V}$ referenced to $\left[\mathrm{Cp}_{2} \mathrm{Fe}\right]^{+/ 0}$ couple.

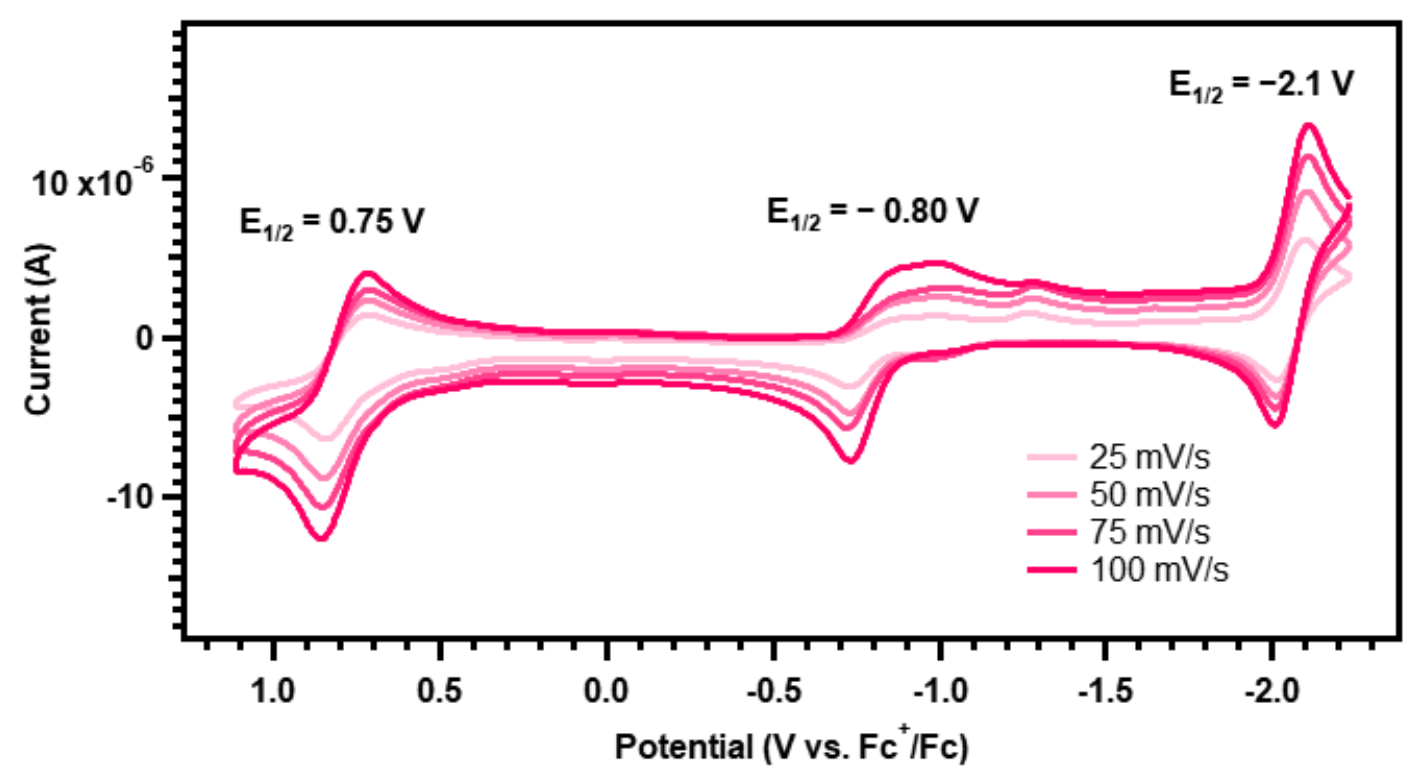

Figure S-13. Cyclic voltammogram of $\left({ }^{\mathrm{Tr}} \mathrm{L}\right) \mathrm{Co}$ (2) in 1,2-difluorobenzene using $0.1 \mathrm{M}$ $\left[{ }^{n} \mathrm{Bu}_{4} \mathrm{~N}\right]\left[\mathrm{PF}_{6}\right]$ as supporting electrolyte at room temperature; scan rate: $25,50,751$ and $100 \mathrm{mV} / \mathrm{s}$, referenced to $\left[\mathrm{Cp}_{2} \mathrm{Fe}\right]^{+/ 0}$ couple. Open circuit potential $=-1.38 \mathrm{~V}$ referenced to $\left[\mathrm{Cp}_{2} \mathrm{Fe}\right]^{+/ 0}$ couple. 


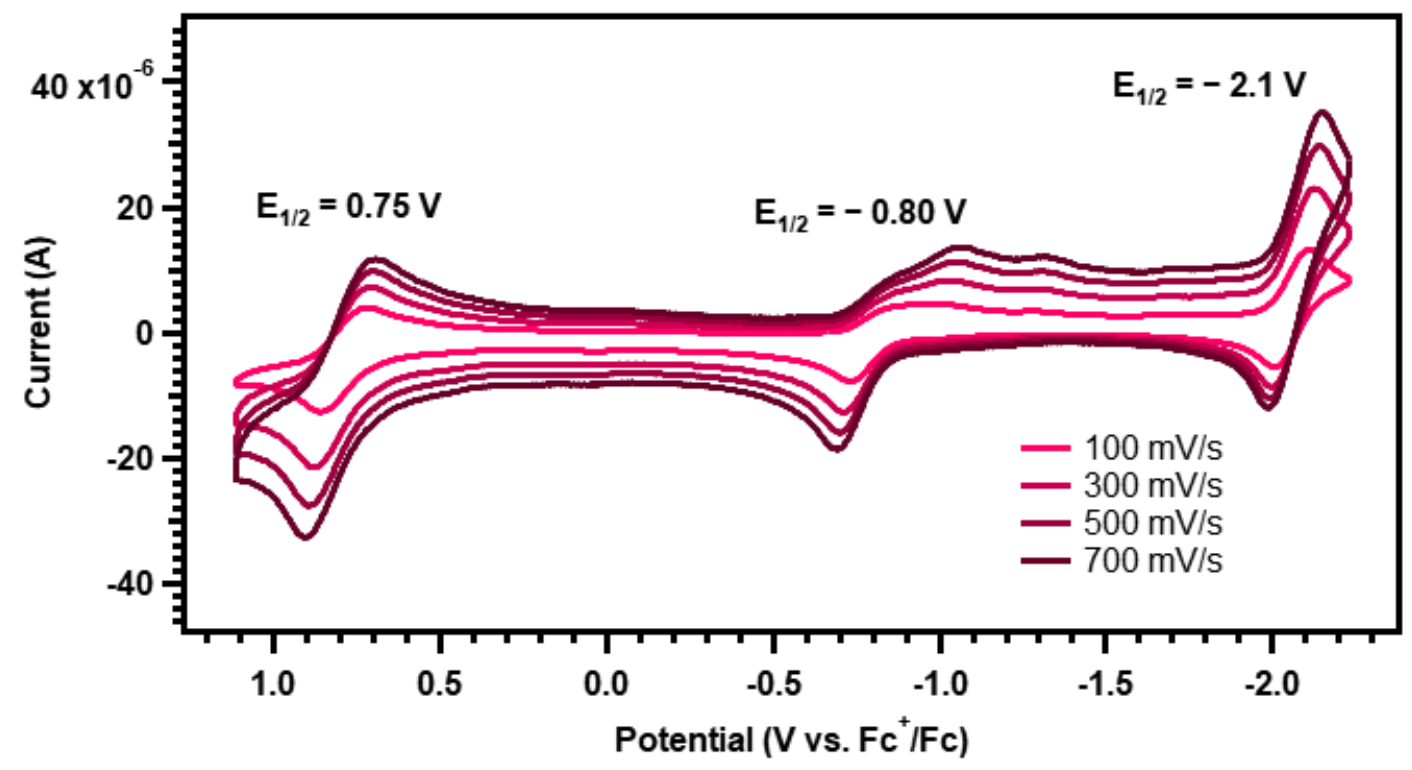

Figure S-14. Cyclic voltammogram of $\left({ }^{\operatorname{Tr}} \mathrm{L}\right) \mathrm{Co}(2)$ in 1,2-difluorobenzene using $0.1 \mathrm{M}$ $\left[{ }^{n} \mathrm{Bu}_{4} \mathrm{~N}\right]\left[\mathrm{PF}_{6}\right]$ as supporting electrolyte at room temperature; scan rate: 100, 300, 500, and 700 $\mathrm{mV} / \mathrm{s}$, referenced to $\left[\mathrm{Cp}_{2} \mathrm{Fe}\right]^{+/ 0}$ couple. Open circuit potential $=-1.38 \mathrm{~V}$ referenced to $\left[\mathrm{Cp}_{2} \mathrm{Fe}\right]^{+/ 0}$ couple.

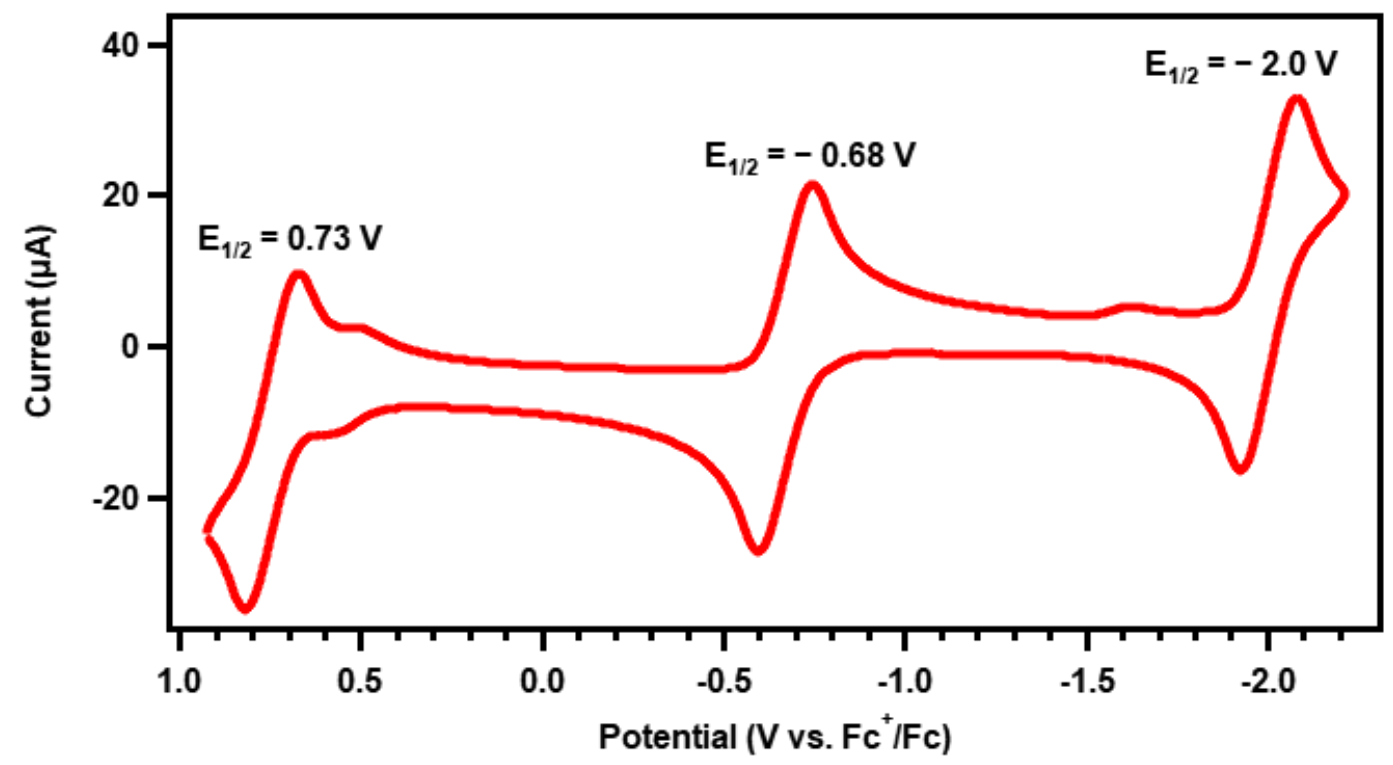

Figure S-15. Cyclic voltammogram of $\left({ }^{\mathrm{Ar}} \mathrm{L}\right) \mathrm{Co}$ in 1,2-difluorobenzene using $0.1 \mathrm{M}\left[{ }^{n} \mathrm{Bu}_{4} \mathrm{~N}\right]\left[\mathrm{PF}_{6}\right]$ as supporting electrolyte at room temperature; scan rate: $100 \mathrm{mV} / \mathrm{s}$, referenced to $\left[\mathrm{Cp}_{2} \mathrm{Fe}\right]^{+/ 0}$ couple. Open circuit potential $=-1.46 \mathrm{~V}$ referenced to $\left[\mathrm{Cp}_{2} \mathrm{Fe}\right]^{+/ 0}$ couple. 


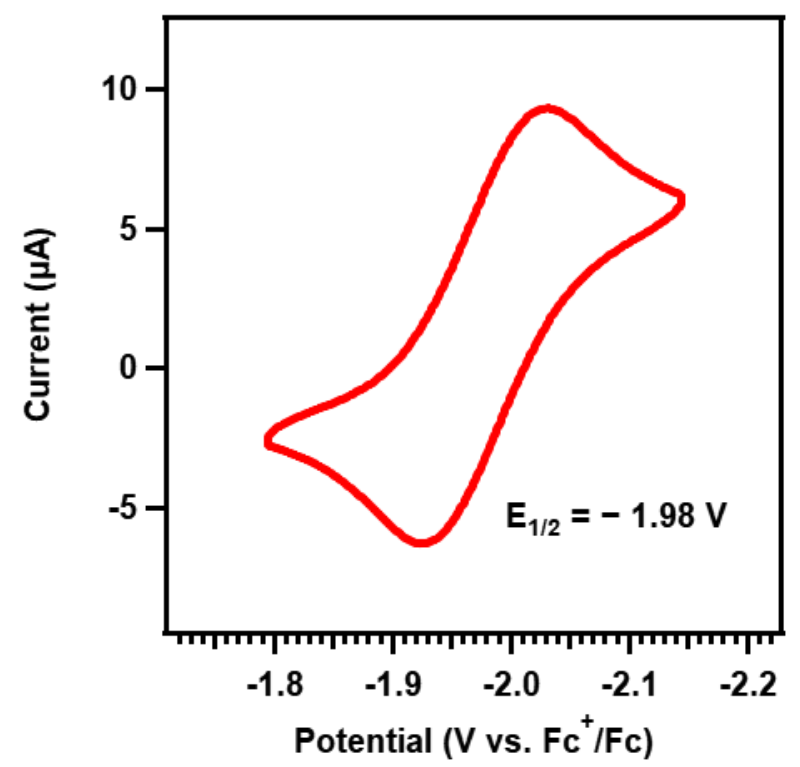

Figure S-16. Cyclic voltammogram of $\left({ }^{\mathrm{Tr}} \mathrm{L}\right) \mathrm{Co}(\mathrm{NAd})(3)$ in 1,2-difluorobenzene using $0.1 \mathrm{M}$ $\left[{ }^{n} \mathrm{Bu}_{4} \mathrm{~N}\right]\left[\mathrm{PF}_{6}\right]$ as supporting electrolyte at room temperature; scan rate: $100 \mathrm{mV} / \mathrm{s}$, referenced to $\left[\mathrm{Cp}_{2} \mathrm{Fe}\right]^{+/ 0}$ couple.

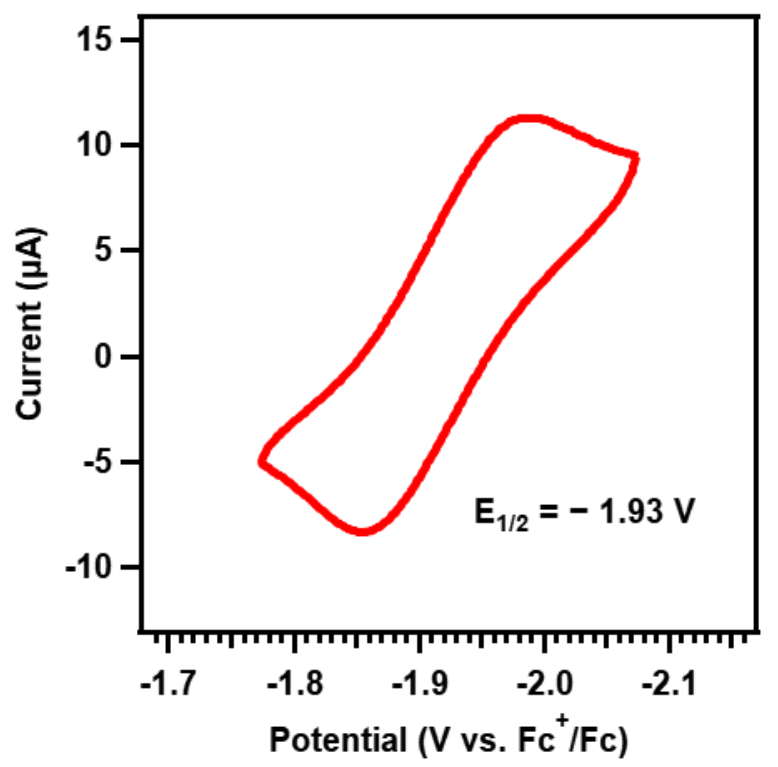

Figure S-17. Cyclic voltammogram of $\left({ }^{\mathrm{Ar}} \mathrm{L}\right) \mathrm{Co}(\mathrm{NAd})(\mathbf{8})$ in 1,2-difluorobenzene using $0.1 \mathrm{M}$ $\left[{ }^{n} \mathrm{Bu}_{4} \mathrm{~N}\right]\left[\mathrm{PF}_{6}\right]$ as supporting electrolyte at room temperature; scan rate: $100 \mathrm{mV} / \mathrm{s}$, referenced to $\left[\mathrm{Cp}_{2} \mathrm{Fe}\right]^{+/ 0}$ couple. 


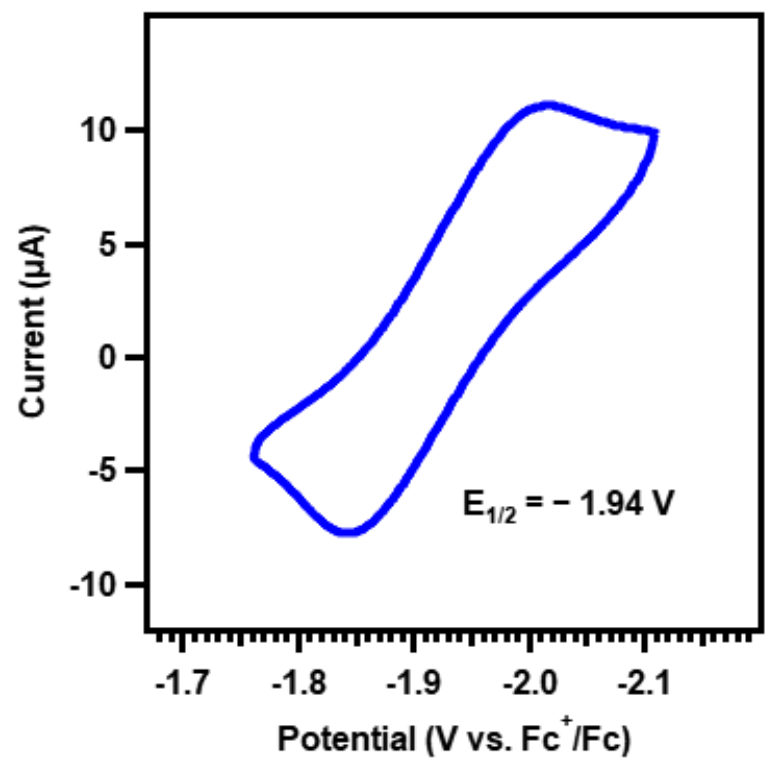

Figure S-18. Cyclic voltammogram of $\left({ }^{\mathrm{Ar}} \mathrm{L}\right) \mathrm{Co}(\mathrm{NAd})(\mathbf{8})$ in THF using $0.1 \mathrm{M}\left[{ }^{n} \mathrm{Bu}_{4} \mathrm{~N}\right]\left[\mathrm{PF}_{6}\right]$ as supporting electrolyte at room temperature; scan rate: $100 \mathrm{mV} / \mathrm{s}$, referenced to $\left[\mathrm{Cp}_{2} \mathrm{Fe}\right]^{+/ 0}$ couple.

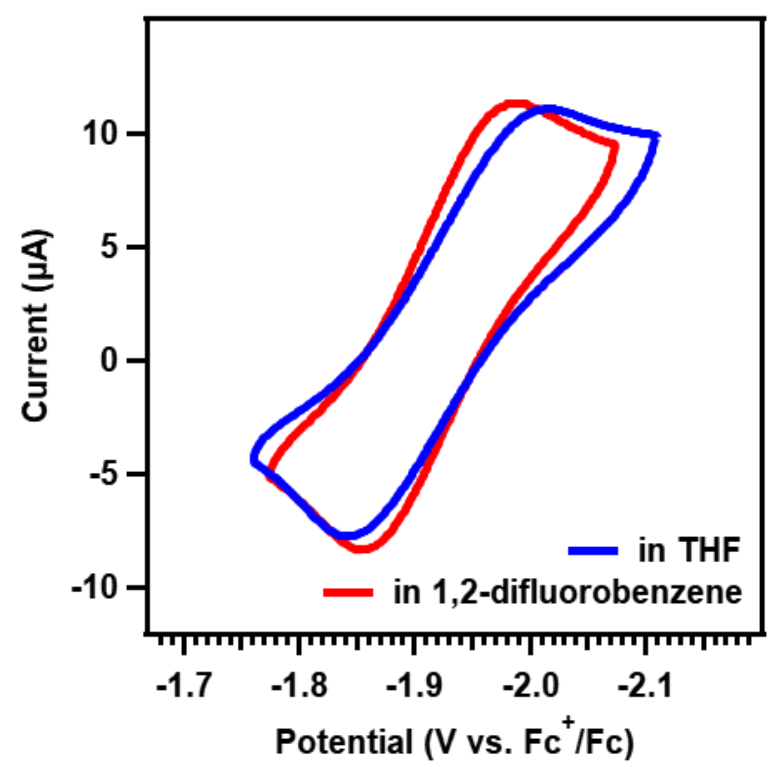

Figure S-19. Stacked cyclic voltammogram of $\left({ }^{\mathrm{Ar}} \mathrm{L}\right) \mathrm{Co}(\mathrm{NAd})(\mathbf{8})$ obtained at room temperature in THF and 1,2-difluorobenzene using $0.1 \mathrm{M}\left[{ }^{n} \mathrm{Bu}_{4} \mathrm{~N}\right]\left[\mathrm{PF}_{6}\right]$ as supporting electrolyte; scan rate: 100 $\mathrm{mV} / \mathrm{s}$, referenced to $\left[\mathrm{Cp}_{2} \mathrm{Fe}\right]^{+/ 0}$ couple. 
Magnetometry Data.

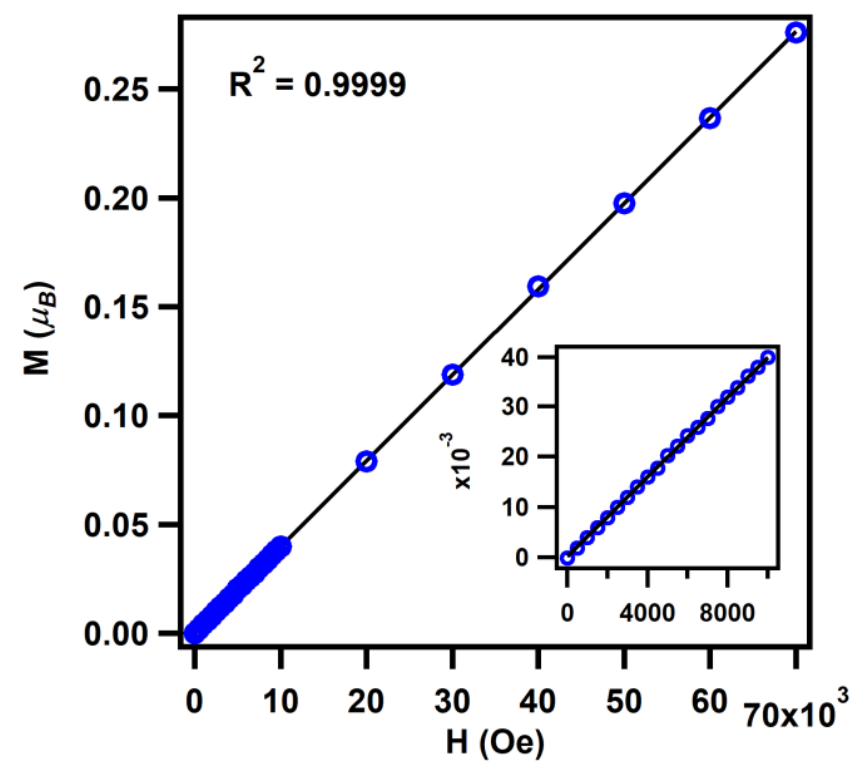

Figure S-20. Magnetization data for $\left({ }^{\mathrm{Tr}} \mathrm{L}\right) \mathrm{CoCl}(\mathbf{1})$. Magnetization versus field collected at $100 \mathrm{~K}$. Linear plot reflects the sample is free from ferromagnetic impurities.

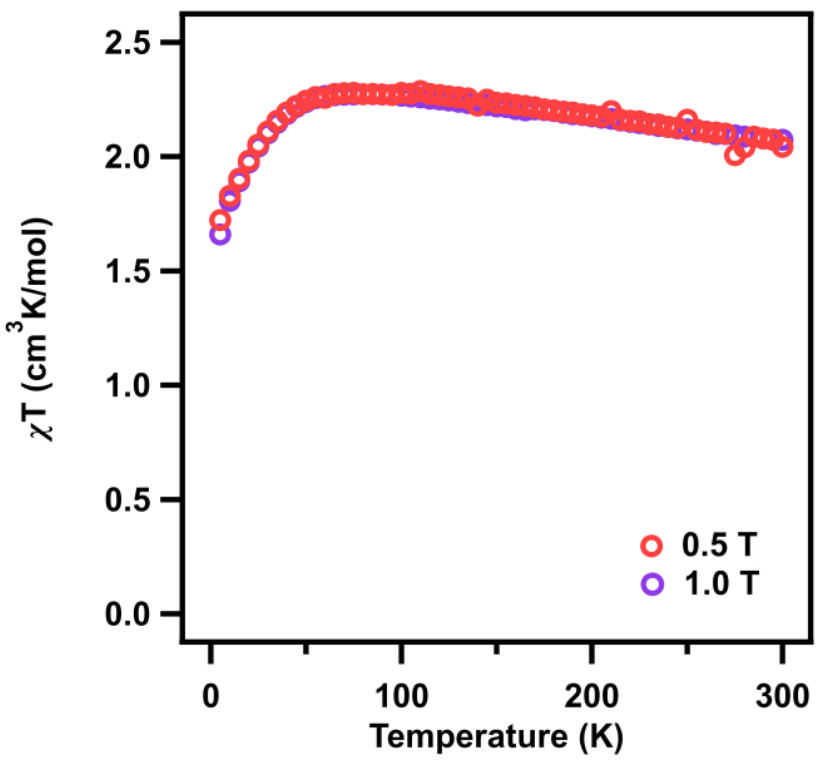

Figure S-21. Variable temperature magnetic susceptibility data of 1 collected at $0.5 \mathrm{~T}$ and $1.0 \mathrm{~T}$. 


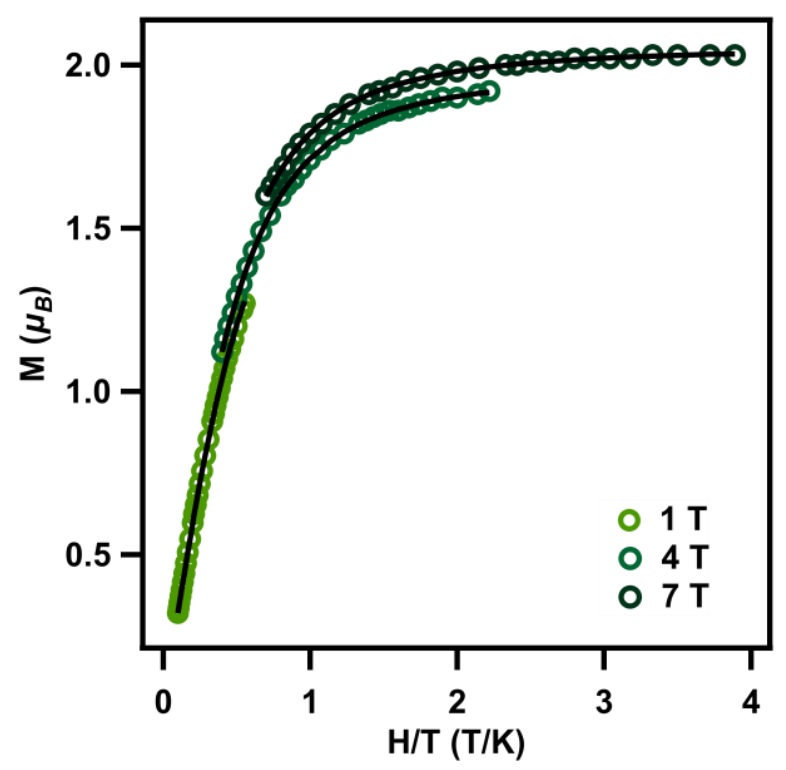

Figure S-22. Reduced magnetization of 1 collected at 3 fields $(1.0,4.0$, and $7.0 \mathrm{~T})$ over the temperature range $1.8-10 \mathrm{~K}$. Magnetization fit parameters obtained with $\mathrm{PHI}^{1}: \mathrm{g}=2.4, \mathrm{D}=-$ $48.1 \mathrm{~cm}^{-1},|\mathrm{E} / \mathrm{D}|=0.11$.

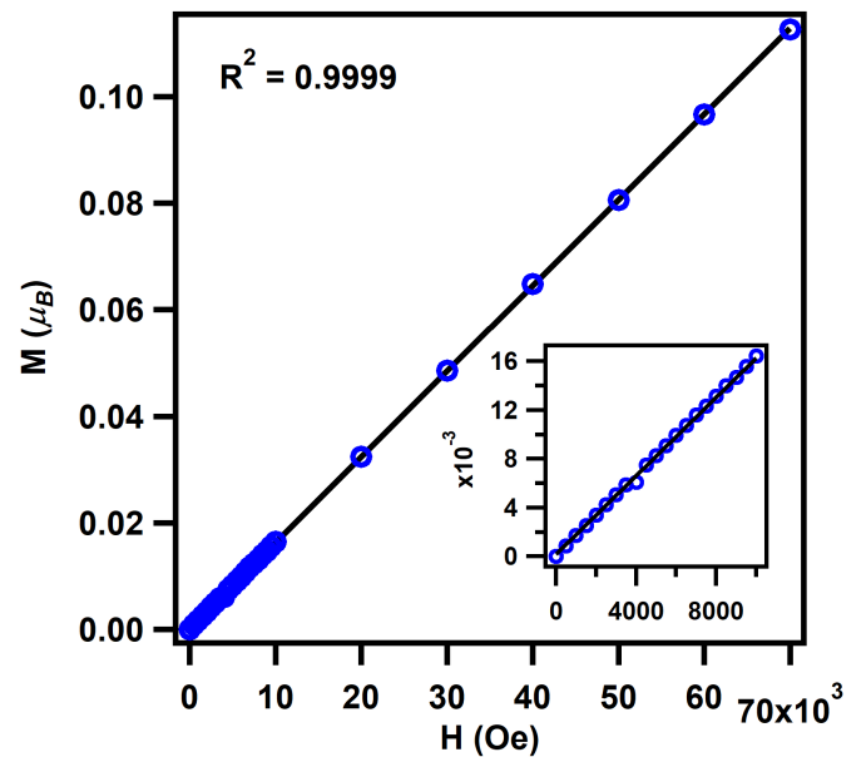

Figure S-23. Magnetization data for $\left({ }^{\mathrm{Tr}} \mathrm{L}\right) \mathrm{Co}(\mathbf{2})$. Magnetization versus field collected at $100 \mathrm{~K}$. Linear plot reflects the sample is free from ferromagnetic impurities. 


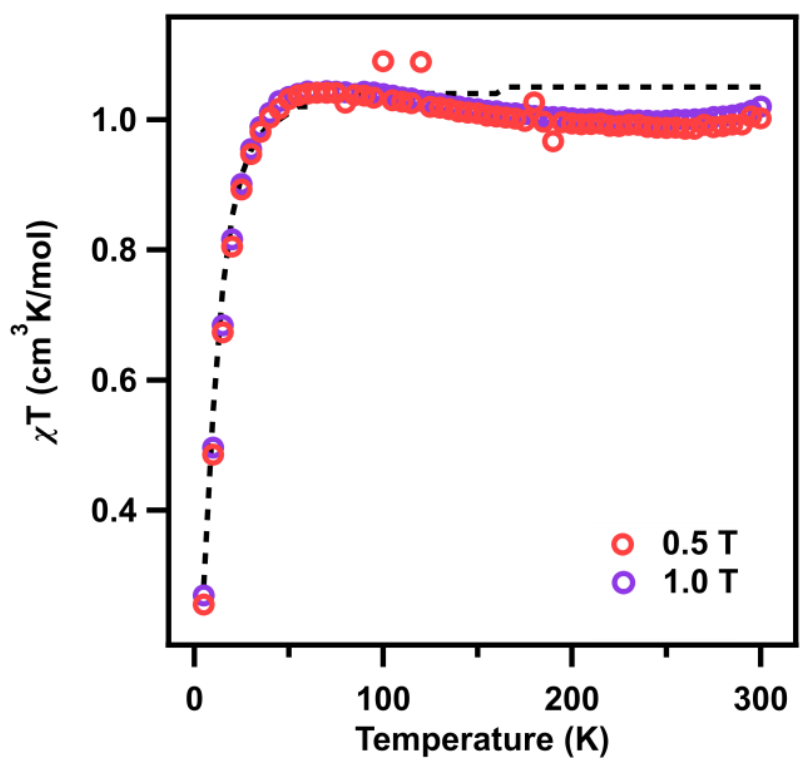

Figure S-24. Variable temperature magnetic susceptibility data of 2 collected at $0.5 \mathrm{~T}$ and $1.0 \mathrm{~T}$. Magnetization fit parameters obtained with $\mathrm{PHI}^{1}$ from the fit of the $\chi_{\mathrm{M}} \mathrm{T}$ data at $1.0 \mathrm{~T}: \mathrm{g}=2.029$, $\mathrm{D}=25.98 \mathrm{~cm}^{-1},\left|{ }^{\mathrm{E}} / \mathrm{D}\right|=0.085$.

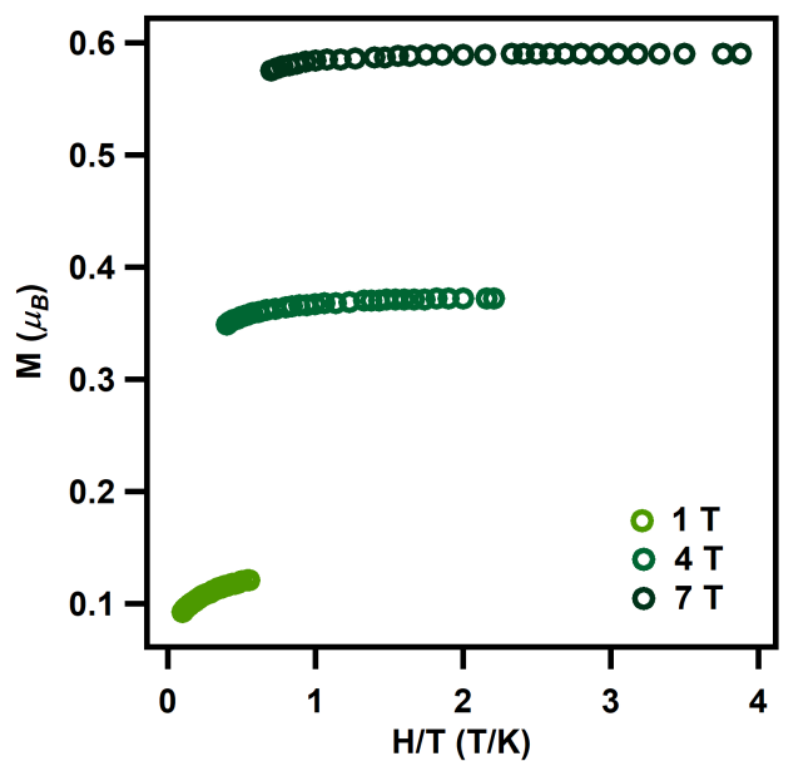

Figure S-25. Reduced magnetization of 2 collected at 3 fields (1.0, 4.0, and 7.0 T) over the temperature range $1.8-10 \mathrm{~K}$. 


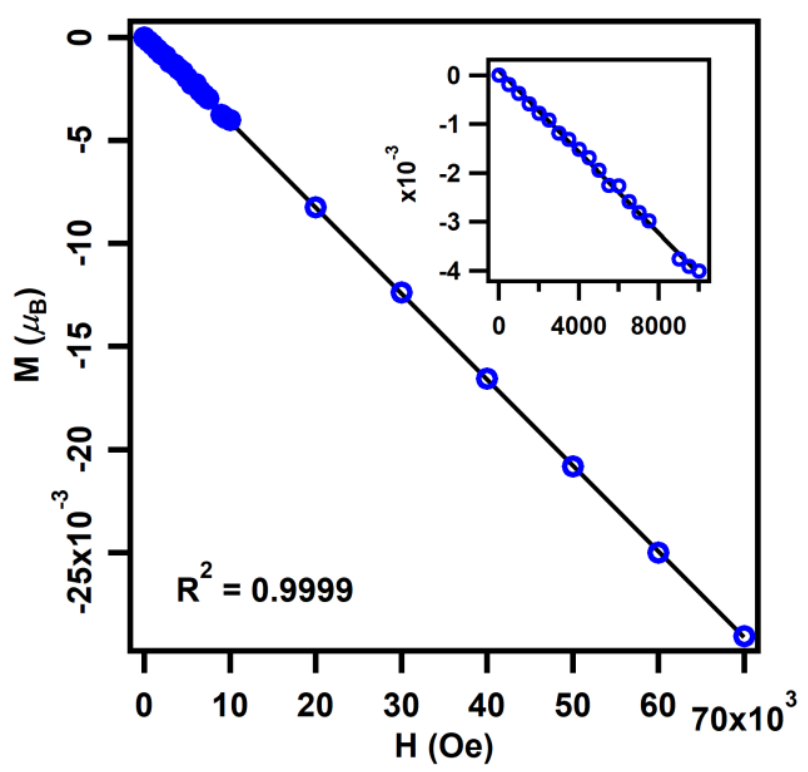

Figure S-26. Magnetization data for $\left({ }^{\mathrm{Tr}} \mathrm{L}\right) \mathrm{Co}(\mathrm{NAd})(3)$. Magnetization versus field collected at $100 \mathrm{~K}$. Linear plot reflects the sample is free from ferromagnetic impurities.

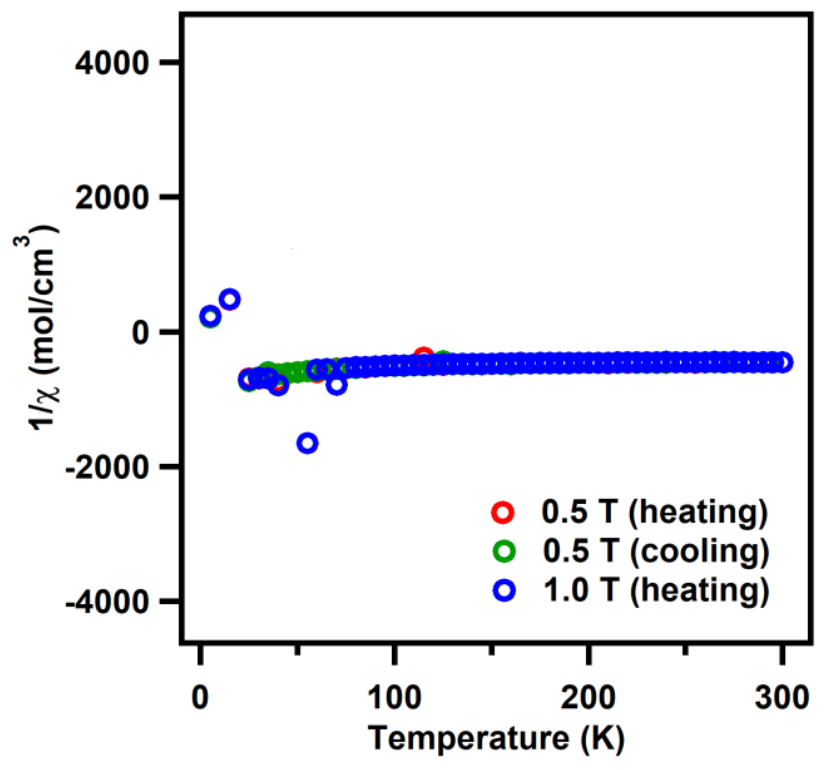

Figure S-27. Variable temperature magnetic susceptibility data of $\mathbf{3}$ collected at $0.5 \mathrm{~T}$ (from $5 \mathrm{~K}$ to $300 \mathrm{~K}$ and going from $300 \mathrm{~K}$ to $5 \mathrm{~K}$ ) and $1.0 \mathrm{~T}$. 
Space-filling Model.
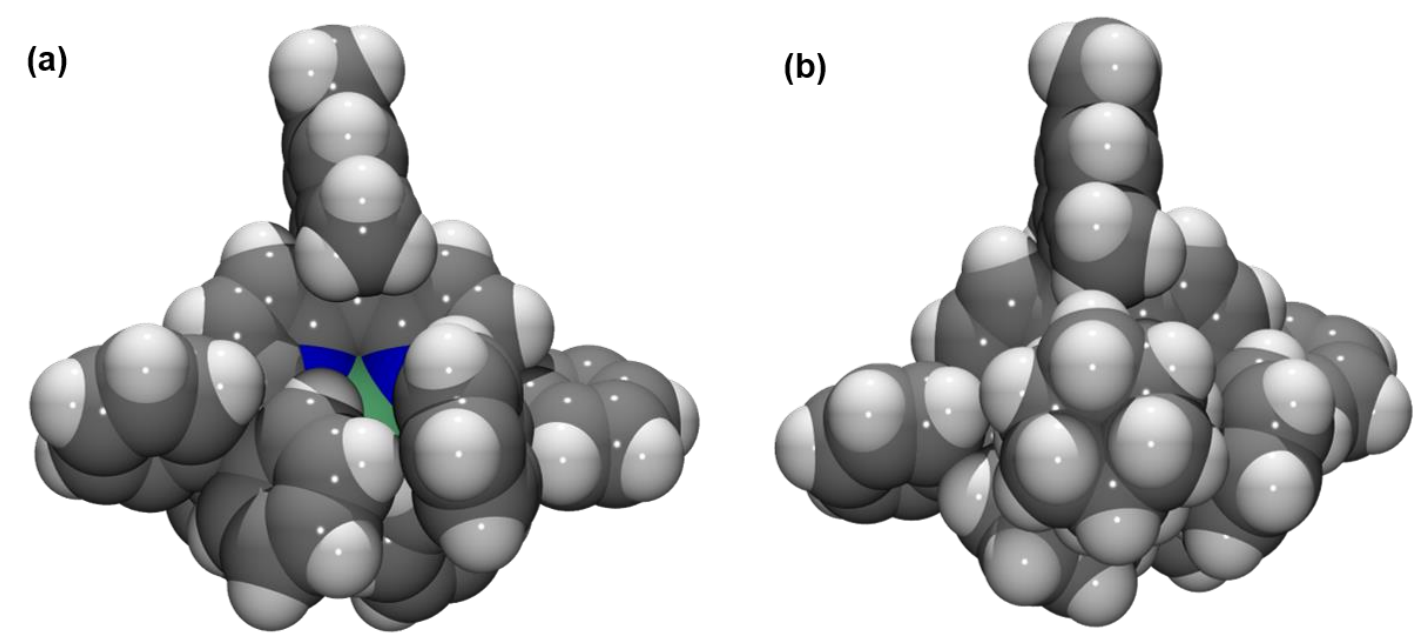

Figure S-28. Space-filling model of $\left({ }^{\mathrm{T}} \mathrm{L}\right) \mathrm{Co}(\mathrm{NAd})(\mathbf{3})$.

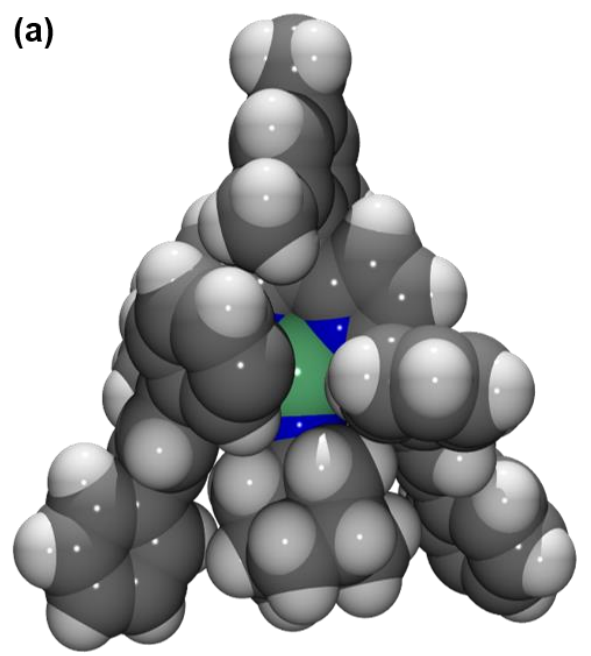

(b)

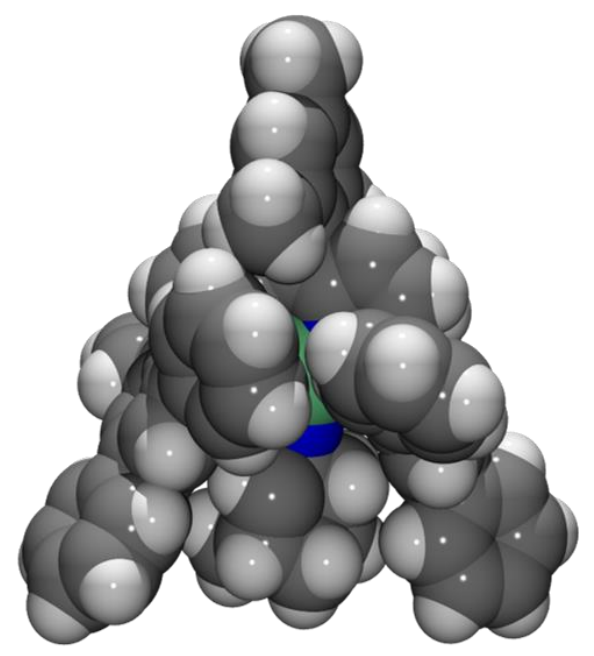

Figure S-29. Space-filling model of $\left({ }^{\mathrm{A}} \mathrm{L}\right) \mathrm{Co}(\mathrm{NAd})(\mathbf{8})$. 


\section{Characterization of Pyrrolidine Products.}

Catalytic reactions. Under an $\mathrm{N}_{2}$ atmosphere, $\left({ }^{\mathrm{Tr}} \mathrm{L}\right) \mathrm{Co}(2)(0.85-8.5 \mathrm{mM}$ in benzene) and the desired azide substrate ( $85.0 \mathrm{mM}$ in benzene) were added to an oven-dried pressure vessel. The reaction mixture was heated to $80{ }^{\circ} \mathrm{C}$ for 12 hours. The crude reaction mixture was concentrated via rotary evaporation and the substituted pyrrolidine was isolated via flash silica chromatography using (EtOAc: $\left.\mathrm{MeOH}: \mathrm{NH}_{4} \mathrm{OH}=10: 1: 0.1\right)$ as an eluent.

\section{(1) 2,2,5-trimethylpyrrolidine}

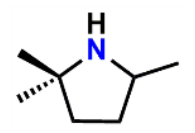

Spectral data were consistent with previously reported characterization of the product. ${ }^{9}$

\section{(2) 2,2,5,5-tetramethylpyrrolidine}

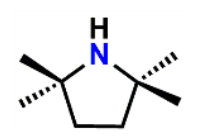

Spectral data were consistent with previously reported characterization of the product. ${ }^{10}$

\section{(3) 2,2-dimethyl-5-phenylpyrrolidine}<smiles>CC1(C)CCC(c2ccccc2)N1</smiles>

Spectral data were consistent with previously reported characterization of the product. ${ }^{4}$ 
(4) 2,2-dimethyl-5-(p-tolyl)pyrrolidine<smiles>Cc1ccc(C2CCC(C)(C)N2)cc1</smiles>

Spectral data were consistent with previously reported characterization of the product. ${ }^{4}$

(5) 5-(4-methoxyphenyl)-2,2-dimethylpyrrolidine<smiles>COc1ccc(C2CCC(C)(C)N2)cc1</smiles>

Spectral data were consistent with previously reported characterization of the product. ${ }^{4}$

(6) 2,2-dimethyl-5-(4-(trifluoromethyl)phenyl)pyrrolidine<smiles>CC1(C)CCC(c2ccc(C(F)(F)F)cc2)N1</smiles>

Spectral data were consistent with previously reported characterization of the product. ${ }^{4}$

(7) 5-(4-fluorophenyl)-2,2-dimethylpyrrolidine<smiles>CC1(C)CCC(c2ccc(F)cc2)N1</smiles>

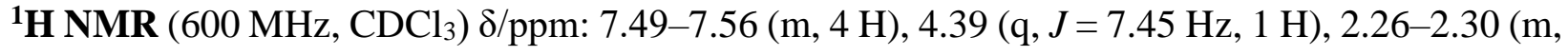
$1 \mathrm{H}), 1.70-1.78(\mathrm{~m}, 3 \mathrm{H}), 1.28(\mathrm{~s}, 3 \mathrm{H}), 1.27$ (s, $3 \mathrm{H}) .{ }^{13} \mathbf{C}\left\{{ }^{1} \mathbf{H}\right\} \mathbf{N M R}\left(125 \mathrm{MHz}, \mathrm{CDCl}_{3}\right) \delta / \mathrm{ppm}$ : $162.82,160.88\left(\mathrm{~d}, J_{\mathrm{C}-\mathrm{F}}=122 \mathrm{~Hz}\right), 141.20,128.17,128.11\left(\mathrm{~d}, J_{\mathrm{C}-\mathrm{F}}=3.97 \mathrm{~Hz}\right), 115.20,115.03(\mathrm{~d}$, $\left.J_{\mathrm{C}-\mathrm{F}}=10.6 \mathrm{~Hz}\right), 61.46,59.24,40.22,35.4330 .88$ 29.72. HRMS (ESI $\left.{ }^{+}\right) \mathrm{m} / z$ Calc. 194.1340 $\left[\mathrm{C}_{12} \mathrm{H}_{16} \mathrm{FN}+\mathrm{H}\right]^{+}$, Found. $194.1340[\mathrm{M}+\mathrm{H}]^{+}$. 
(8) 2-methyl-1-azaspiro[4.5]decane

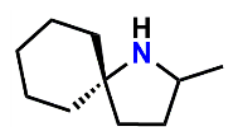

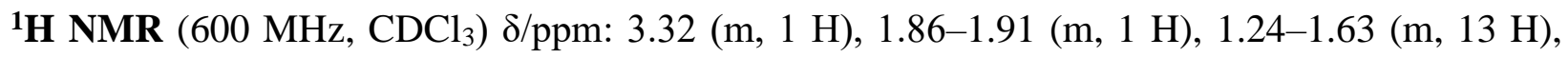
1.13-1.14 (d, $J=4.14 \mathrm{~Hz}, 3 \mathrm{H}) .{ }^{13} \mathbf{C}\left\{{ }^{1} \mathbf{H}\right\}$ NMR (125 MHz, $\left.\mathrm{CDCl}_{3}\right) \delta / p p m: 61.40,59.18,40.17$, 35.38, 30.83, 29.67. HRMS $\left(\mathrm{ESI}^{+}\right) \mathrm{m} / z$ Calc. $154.1590\left[\mathrm{C}_{10} \mathrm{H}_{19} \mathrm{~N}+\mathrm{H}\right]^{+}$, Found. $154.1590[\mathrm{M}+\mathrm{H}]^{+}$.

\section{(9) 2,2-dimethylpyrrolidine}

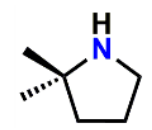

Spectral data were consistent with previously reported characterization of the product. ${ }^{11}$ 


\section{Computational Methods for Probing $\mathrm{p} K_{\mathrm{a}}$ of Cobalt(II) Amide Complexes.}

Theoretical Measurements. All calculations were performed using density functional theory and the quantum chemical program package Gaussian16 using the unrestricted B3LYP hybrid functional (which includes the Becke three-parameter exchange and the Lee, Yang, and Parr correlation functional) and GD3BJ dispersion of Grimme et al. with Becke-Johnson damping. ${ }^{12}$ The SDD basis set was used in the investigation, which combines the Dunning/Huzinaga valence double-zeta basis for elements up to Ar, with the Stuttgart/Dresden effective core potentials for the remainder of the periodic table. ${ }^{13,14,15}$ This particular method and level of theory was reported by Smith et al. in 2008 and was found to provide appropriate accuracy in similar thermodynamic estimations of $\mathrm{p} K_{\mathrm{a}}$ values for iron complexes ${ }^{16}$ and they recently reported accurate theoretical determination of numerous $\mathrm{p} K_{\mathrm{a}}$ values for acids in THF. ${ }^{17}$ Thus, given that 1,2-difluorobenzene and tetrahydrofuran share similar physical properties (e.g., dielectric constant and dipole moment), solvation of the molecular species was modelled using continuum parameters designed to describe the tetrahydrofuran solvent $(\varepsilon=7.43)$. This estimation is further supported by the almost identical $\mathrm{E}^{\circ}$ red of complex 3 measured in either 1,2-difluorobenzene or tetrahydrofuran (Figure S-19). Geometry optimizations were performed in order to obtain electronic energies, followed by frequency calculations to compute zero-point energies and derive values for thermal and entropic corrections at $298.15 \mathrm{~K}$. Considering a general acid-base reaction between a cobalt amide species (LCo(NHAd), 3a and 8a) and its deprotonated from [LCo(NAd) $]^{-}$:

$$
\mathrm{LCo}(\mathrm{NHAd})+[\mathrm{A}]^{-} \rightarrow[\mathrm{LCo}(\mathrm{NAd})]^{-}+\mathrm{HA}
$$

where HA is a weak acid with a previously reported $\mathrm{p} K_{\mathrm{a}}$ value in THF. ${ }^{17}$ The overall free energy of the reaction is thus satisfied by the relationship:

$$
\Delta \mathrm{G}=2.303 \mathrm{RT}\left[\mathrm{p} K_{\mathrm{a}}(\mathrm{LCo}(\mathrm{NHAd}))-\mathrm{p} K_{\mathrm{a}}(\mathrm{HA})\right]
$$

where $\mathrm{p} K_{\mathrm{a}}\left([\mathrm{LCo}(\mathrm{NHAd}))\right.$ and $\mathrm{p} K_{\mathrm{a}}(\mathrm{HA})$ denote the $\mathrm{p} K_{\mathrm{a}}$ values for the LCo(NHAd) and HA, respectively. As described by Smith et al., using this method one evaluates the relative free energy with respect to a known weak acid, HA, and thus bypasses the explicit treatment of the solvated proton. 
Table S-6. Calculated $\mathrm{p} K_{\mathrm{a}}$ values of $\left({ }^{\mathrm{Tr}} \mathrm{L}\right) \mathrm{Co}(\mathrm{NHAd})(\mathbf{3 a})$ with respect to different reference acids.

\begin{tabular}{c|c} 
Reference Acid & Calculated $\left.\mathbf{p} K_{\mathbf{a}} \mathbf{~ o f}\left({ }^{\mathbf{T r}} \mathbf{L}\right) \mathbf{C o}(\mathbf{N H A d}) \mathbf{3 a}\right)$ \\
\hline Lutidinium & 62.3 \\
\hline Benzoic Acid & 61.6 \\
\hline Acetic Acid & 61.3 \\
\hline Phenol & 60.5 \\
\hline 2,2,2-trifluoroethanol & 61.5 \\
\hline Acetone & 58.1 \\
\hline Average & 60.9
\end{tabular}

Table S-7. Calculated $\mathrm{p} K_{\mathrm{a}}$ values $\left({ }^{\mathrm{Ar}} \mathrm{L}\right) \mathrm{Co}(\mathrm{NHAd})(\mathbf{8 a})$ with respect to different reference acids.

\begin{tabular}{c|c} 
Reference Acid & Calculated $\mathbf{p} \boldsymbol{K}_{\mathbf{a}}$ of $\left({ }^{\mathbf{A r}} \mathbf{L}\right) \mathbf{C o}(\mathbf{N H A d})(\mathbf{8 a})$ \\
\hline Lutidinium & 57.2 \\
\hline Benzoic Acid & 56.5 \\
\hline Acetic Acid & 56.2 \\
\hline Phenol & 55.4 \\
\hline 2,2,2-trifluoroethanol & 56.4 \\
\hline Acetone & 53.0 \\
\hline Average & 55.8 \\
\hline
\end{tabular}


NMR Spectra of Metal Complexes.

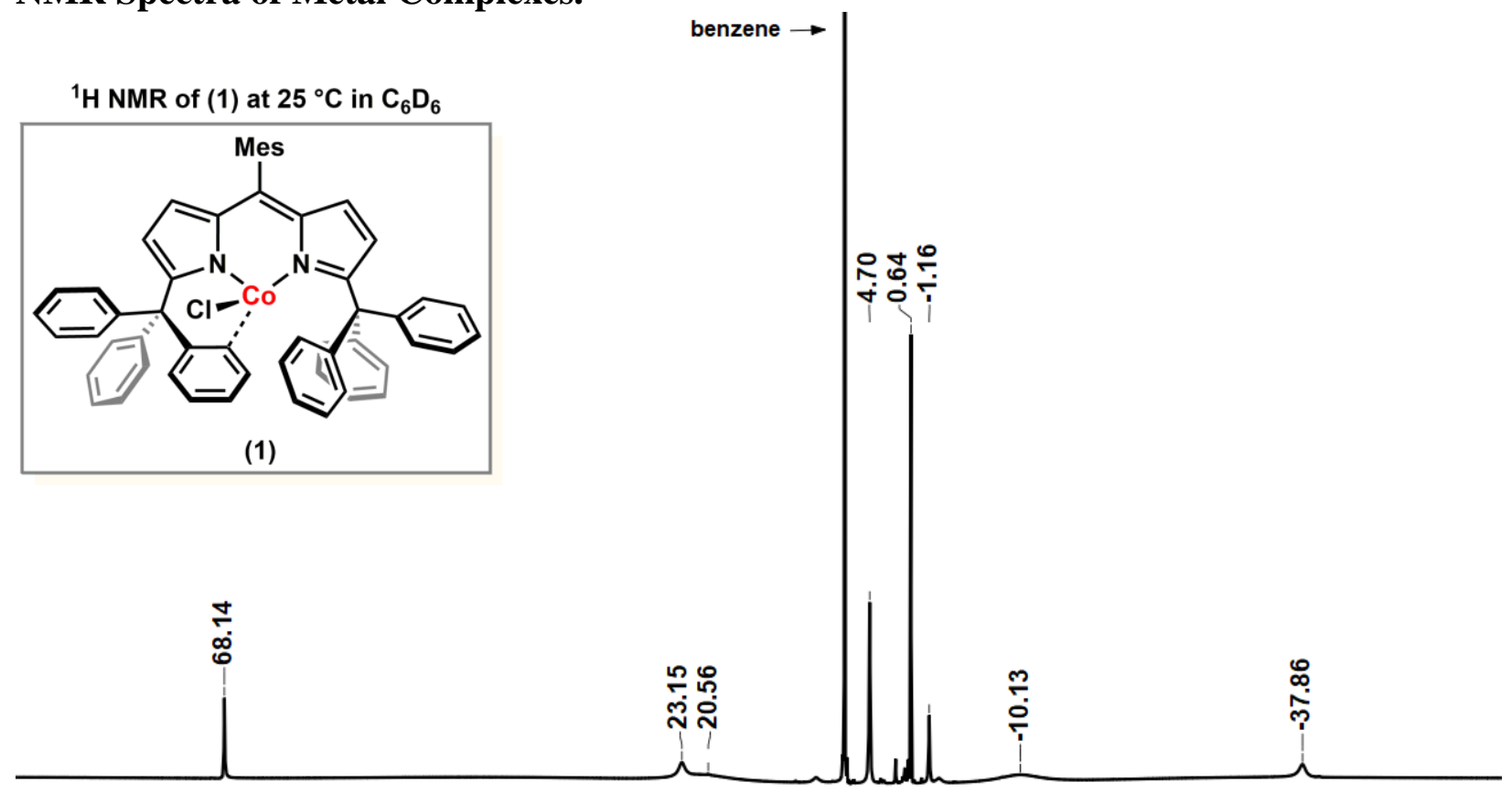

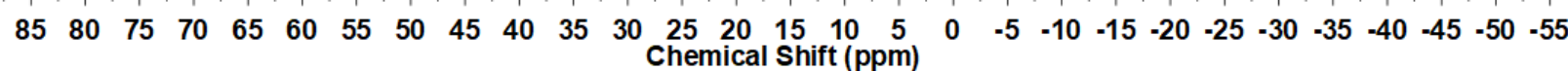

Figure S-30. $600 \mathrm{MHz}{ }^{1} \mathrm{H}$ NMR spectrum of $\left({ }^{\mathrm{Tr}} \mathrm{L}\right) \mathrm{CoCl}(\mathbf{1})$ in benzene- $d_{6}$.

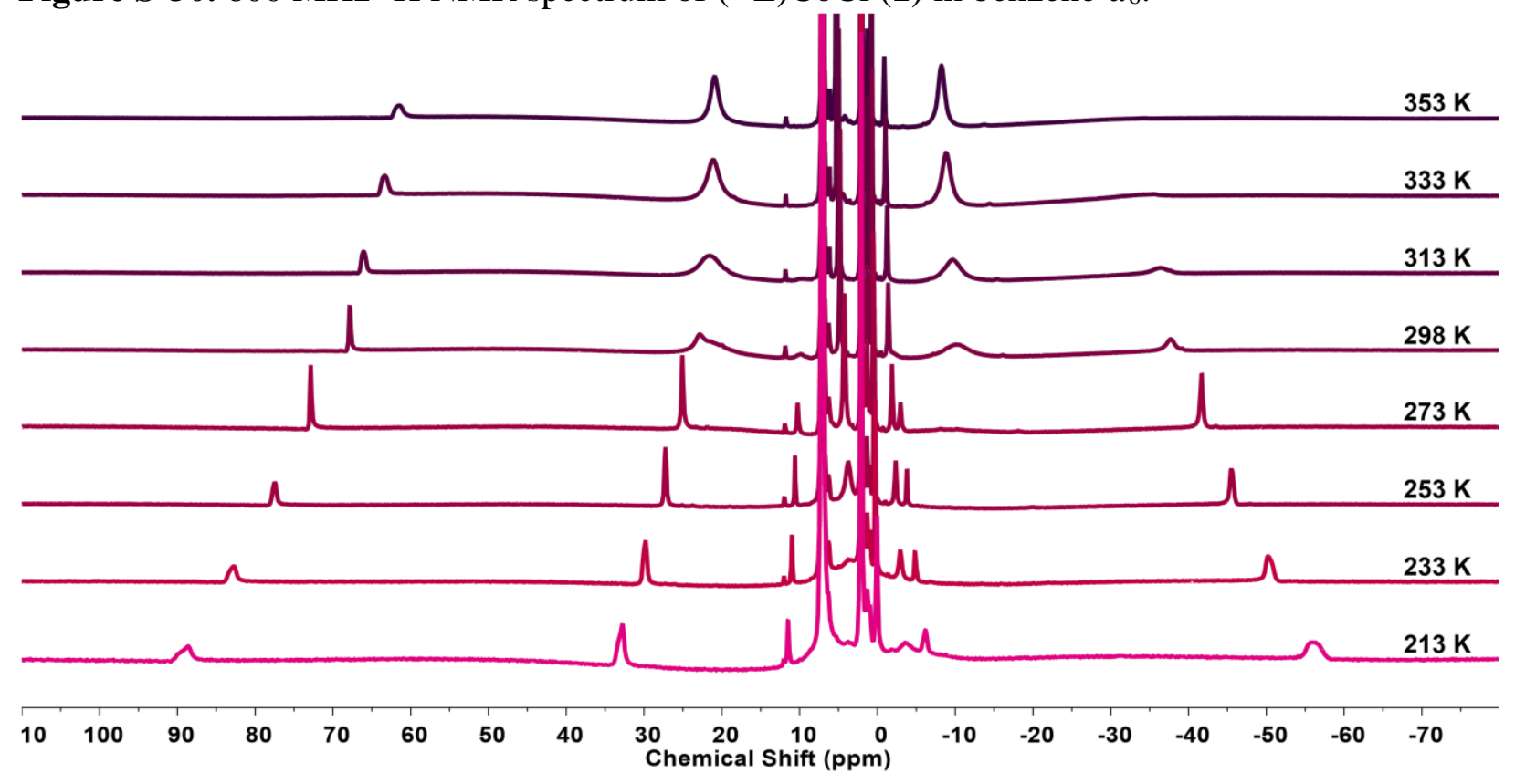

Figure S-31. $500 \mathrm{MHz}{ }^{1} \mathrm{H}$ NMR spectra of $\left({ }^{\mathrm{Tr}} \mathrm{L}\right) \mathrm{CoCl}(\mathbf{1})$ in toluene- $d 8$. 

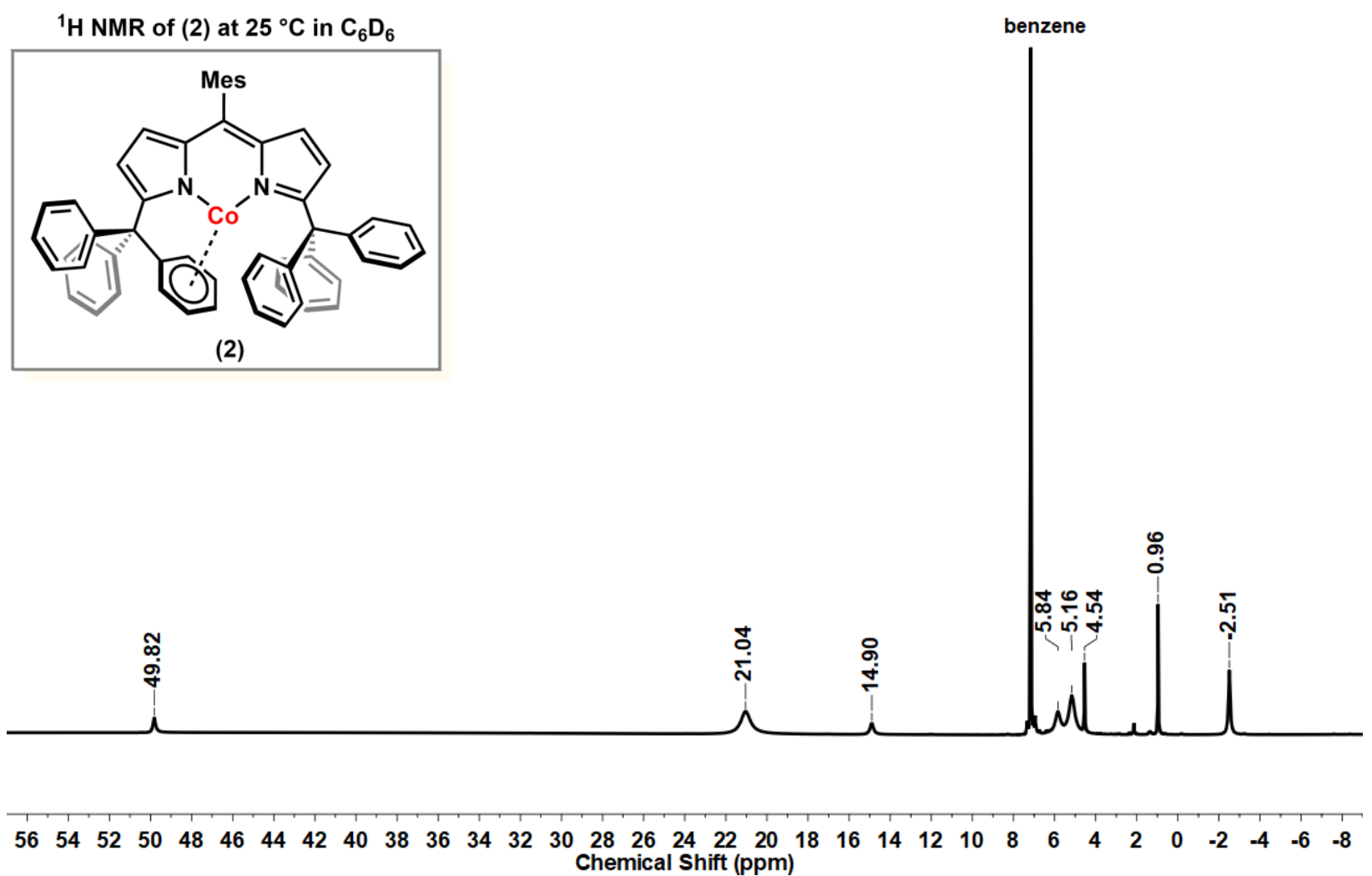

Figure S-32. $600 \mathrm{MHz}{ }^{1} \mathrm{H}$ NMR spectrum of $\left({ }^{\mathrm{Tr}} \mathrm{L}\right) \mathrm{Co}(2)$ in benzene- $d_{6}$.

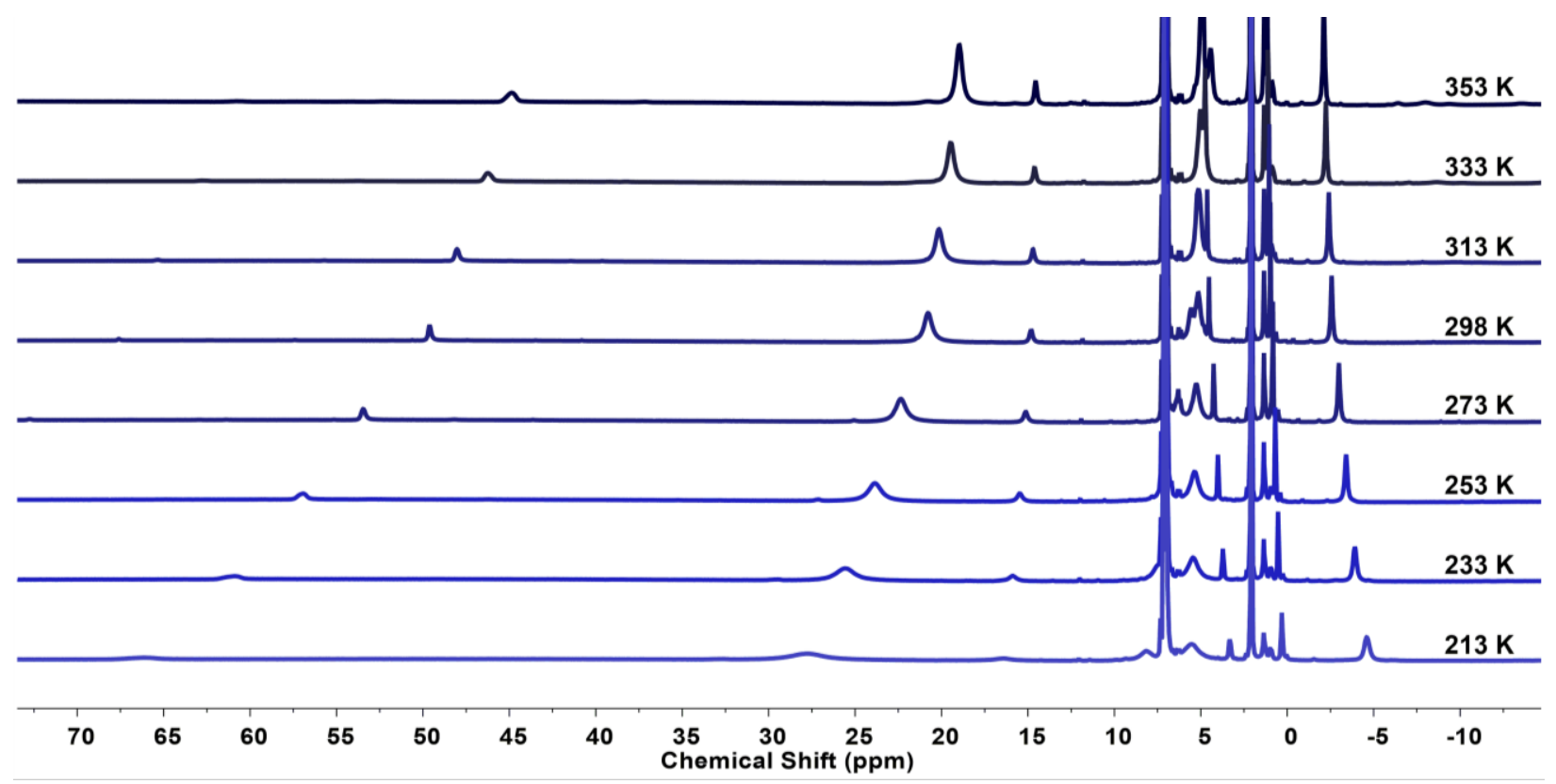

Figure S-33. $500 \mathrm{MHz}$ Variable temperature ${ }^{1} \mathrm{H}$ NMR spectra of $\left({ }^{\mathrm{Tr}} \mathrm{L}\right) \mathrm{Co}(2)$ in toluene- $d_{8}$. 


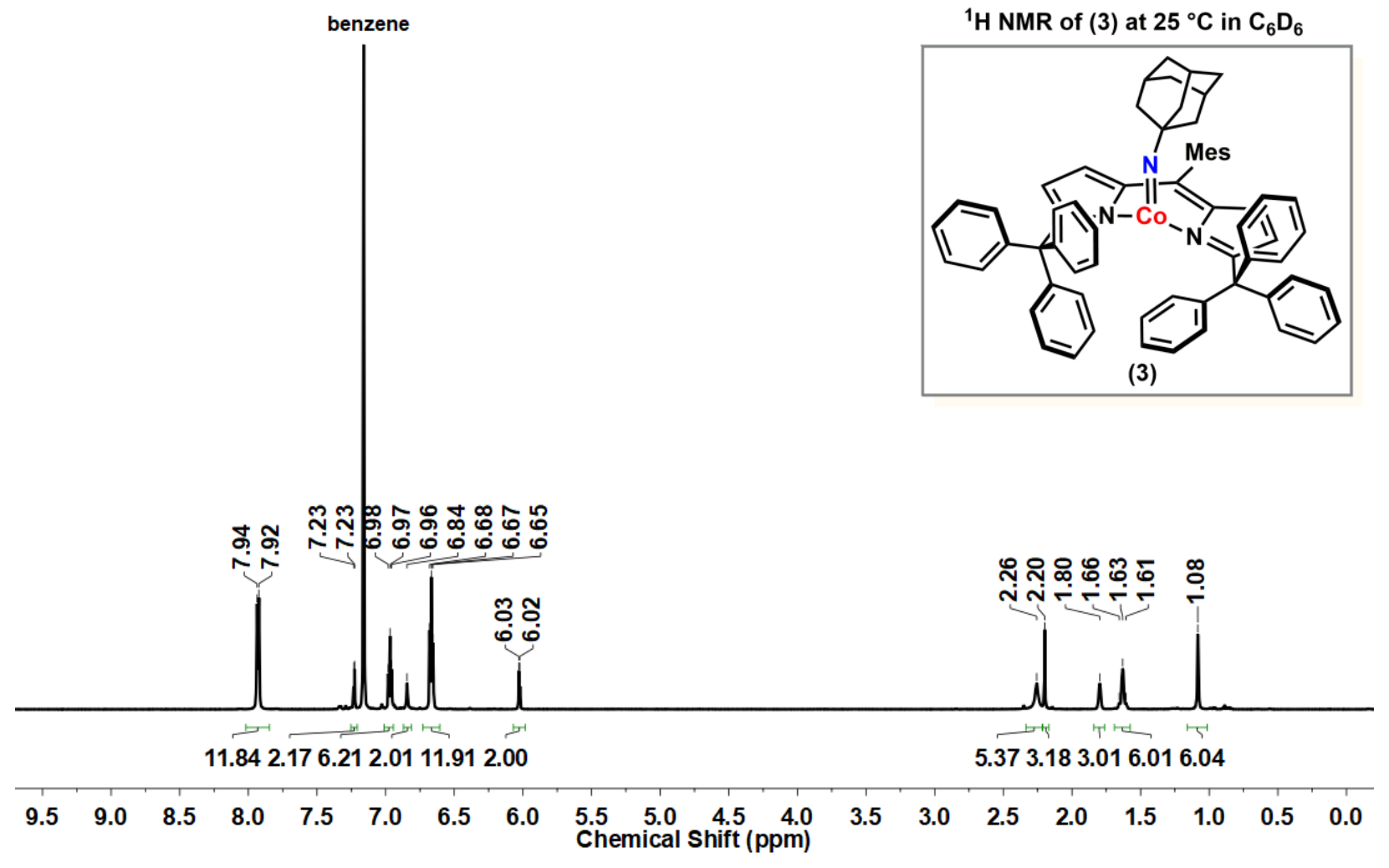

Figure S-34. $600 \mathrm{MHz}{ }^{1} \mathrm{H}$ NMR spectrum of $\left({ }^{\mathrm{Tr}} \mathrm{L}\right) \mathrm{Co}(\mathrm{NAd})(3)$ in benzene- $d_{6}$.

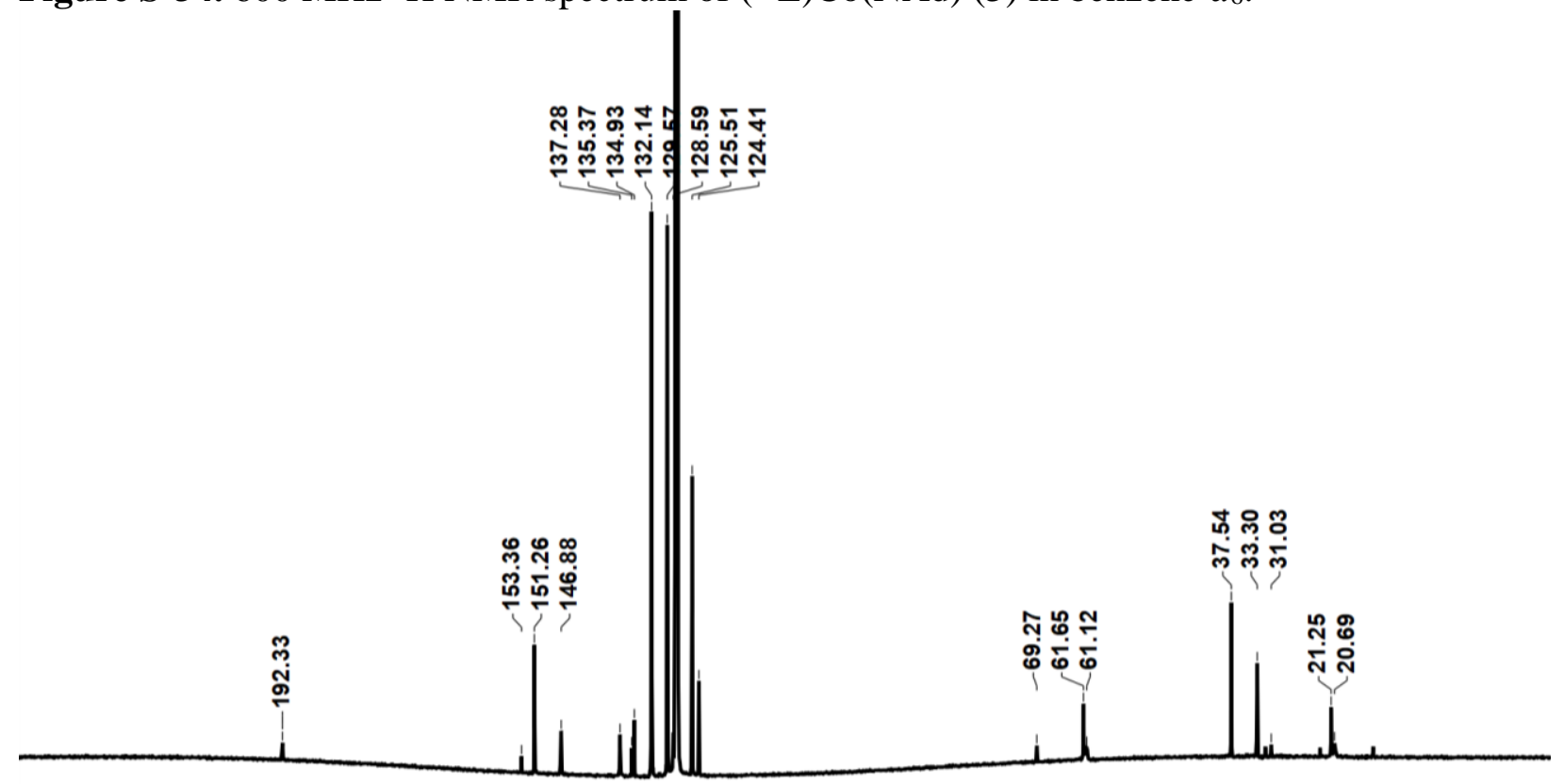

$\begin{array}{llllllllllllllllllllllll}230 & 220 & 210 & 200 & 190 & 180 & 170 & 160 & 150 & 140 & \begin{array}{c}130 \quad 120 \\ \text { Chemical Shift (ppm) }\end{array} & 80 & 70 & 60 & 50 & 40 & 30 & 20 & 10 & 0 & -10\end{array}$

Figure S-35. $125 \mathrm{MHz}{ }^{13} \mathrm{C}\left\{{ }^{1} \mathrm{H}\right\}$ NMR spectrum of $\left({ }^{\mathrm{Tr}} \mathrm{L}\right) \mathrm{Co}(\mathrm{NAd})(\mathbf{3})$ in benzene- $d 6$. 
${ }^{1} \mathrm{H}$ NMR of (4) at $25^{\circ} \mathrm{C}$ in $\mathrm{C}_{6} \mathrm{D}_{6}$
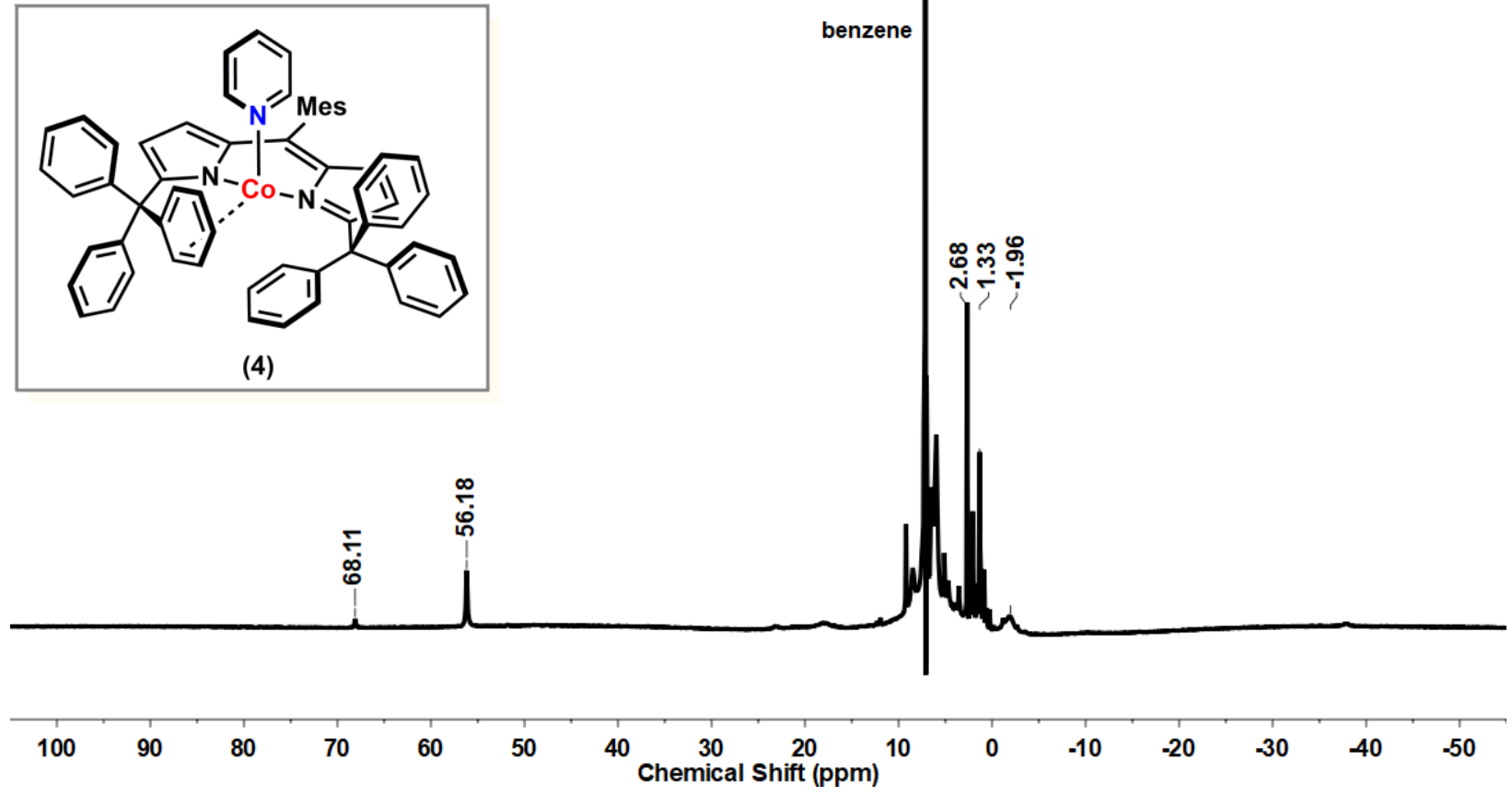

Figure S-36. $600 \mathrm{MHz}{ }^{1} \mathrm{H}$ NMR spectrum of $\left({ }^{\operatorname{Tr}} \mathrm{L}\right) \mathrm{Co}(\mathrm{py})(4)$ in benzene- $d_{6}$. 


\section{NMR Spectra of Organic Compounds.}

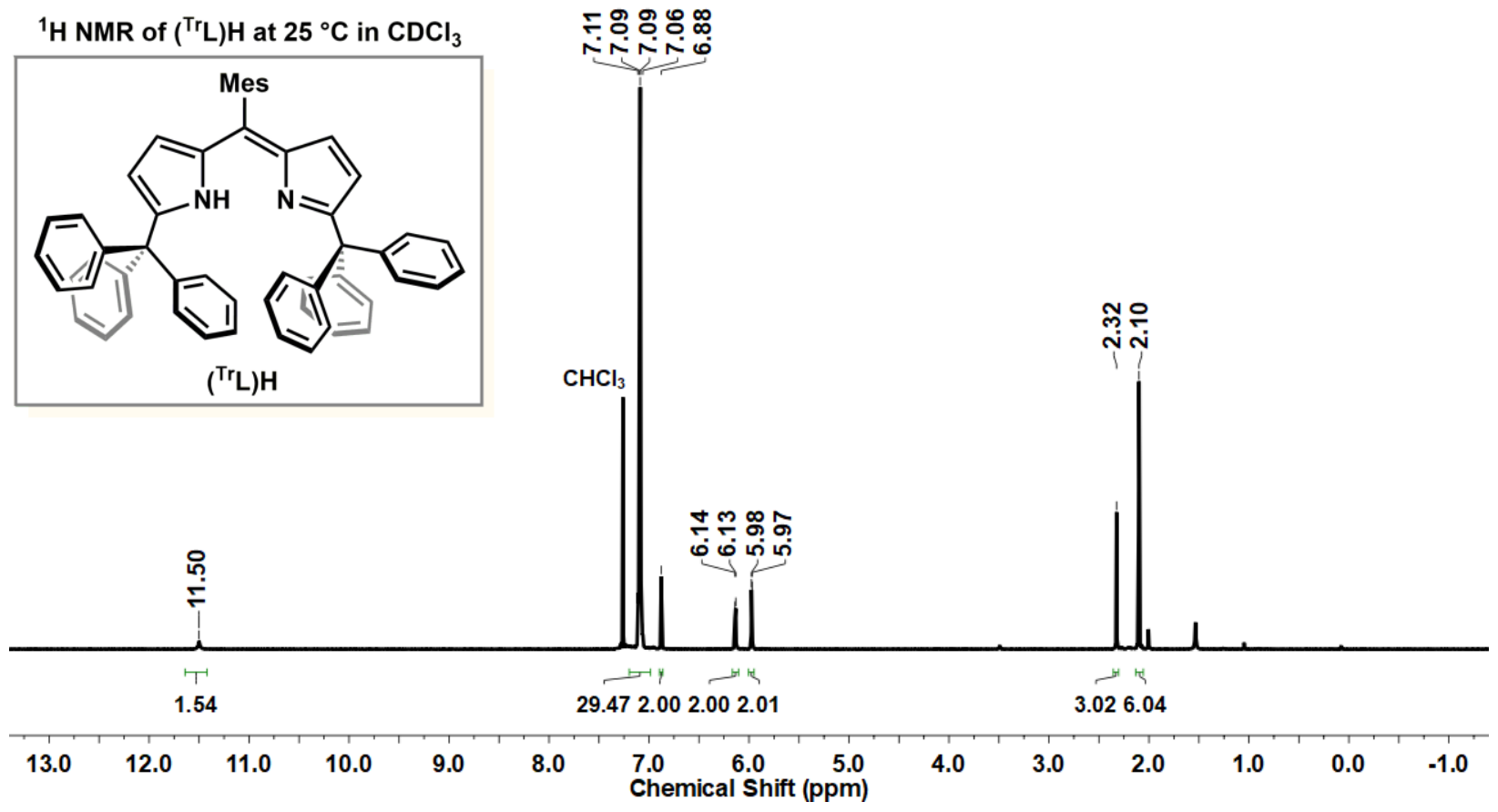

Figure S-37. $600 \mathrm{MHz}{ }^{1} \mathrm{H}$ NMR spectrum of $\left({ }^{\mathrm{Tr}} \mathrm{L}\right) \mathrm{H}$ in chloroform- $d$.
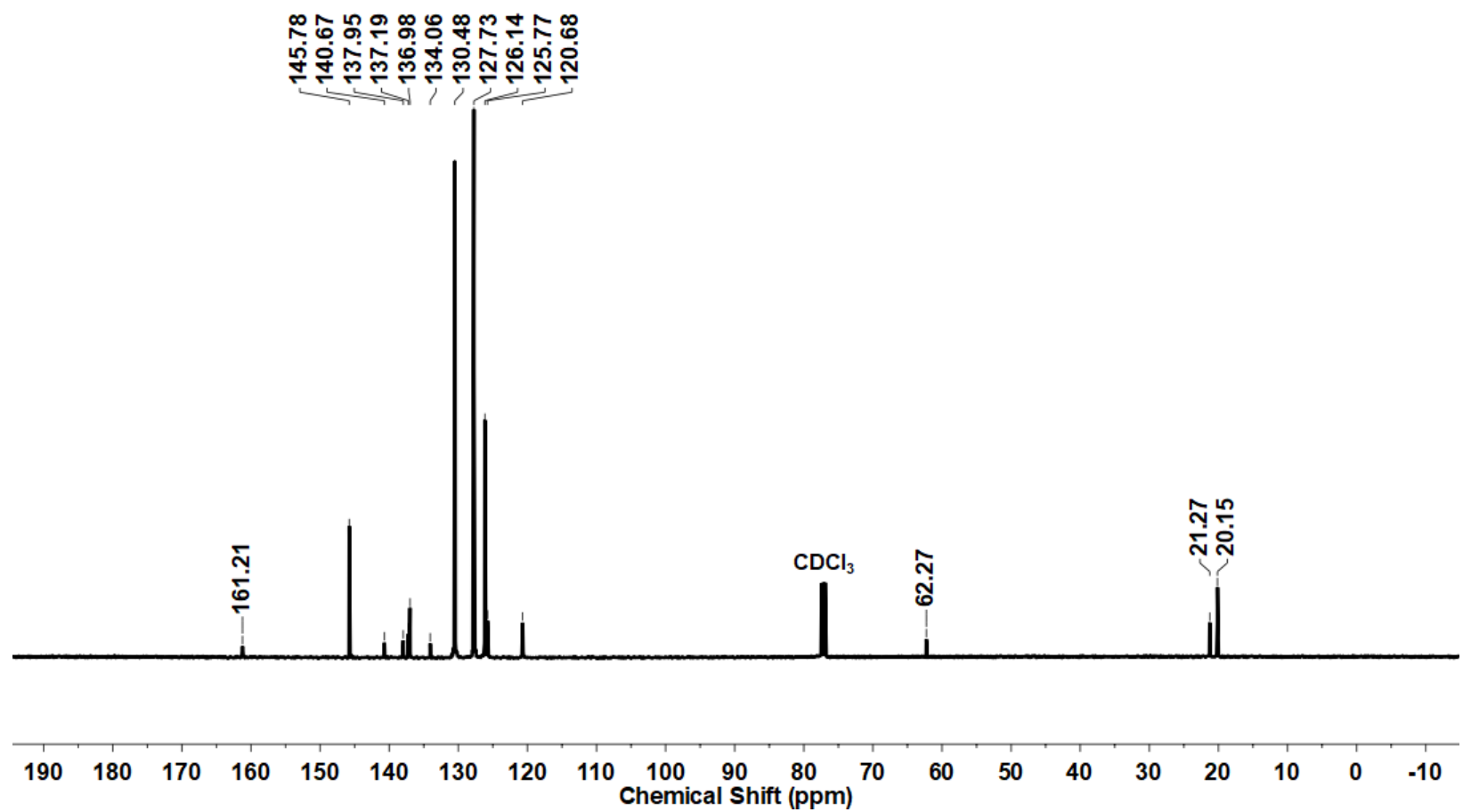

Figure S-38. $125 \mathrm{MHz}{ }^{13} \mathrm{C}\left\{{ }^{1} \mathrm{H}\right\}$ NMR spectrum of $\left({ }^{\mathrm{Tr}} \mathrm{L}\right) \mathrm{H}$ in chloroform- $d$. 


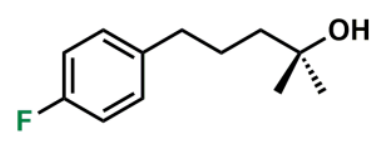

${ }^{1} \mathrm{H}$ NMR at $25^{\circ} \mathrm{C}$ in $\mathrm{CDCl}_{3}$

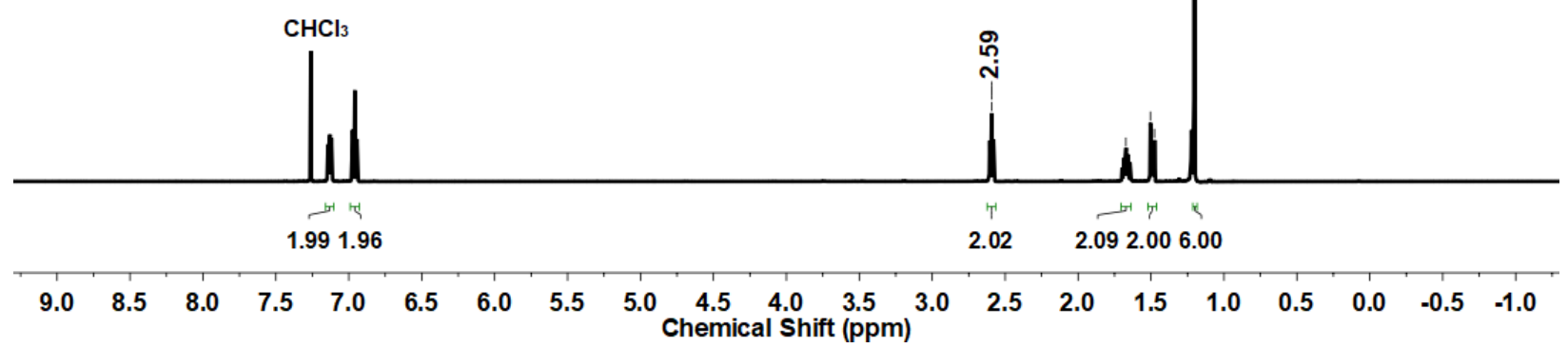

Figure S-39. $600 \mathrm{MHz}{ }^{1} \mathrm{H}$ NMR spectrum of 5-(4-fluorophenyl)-2-methylpentan-2-ol in chloroform- $d$.
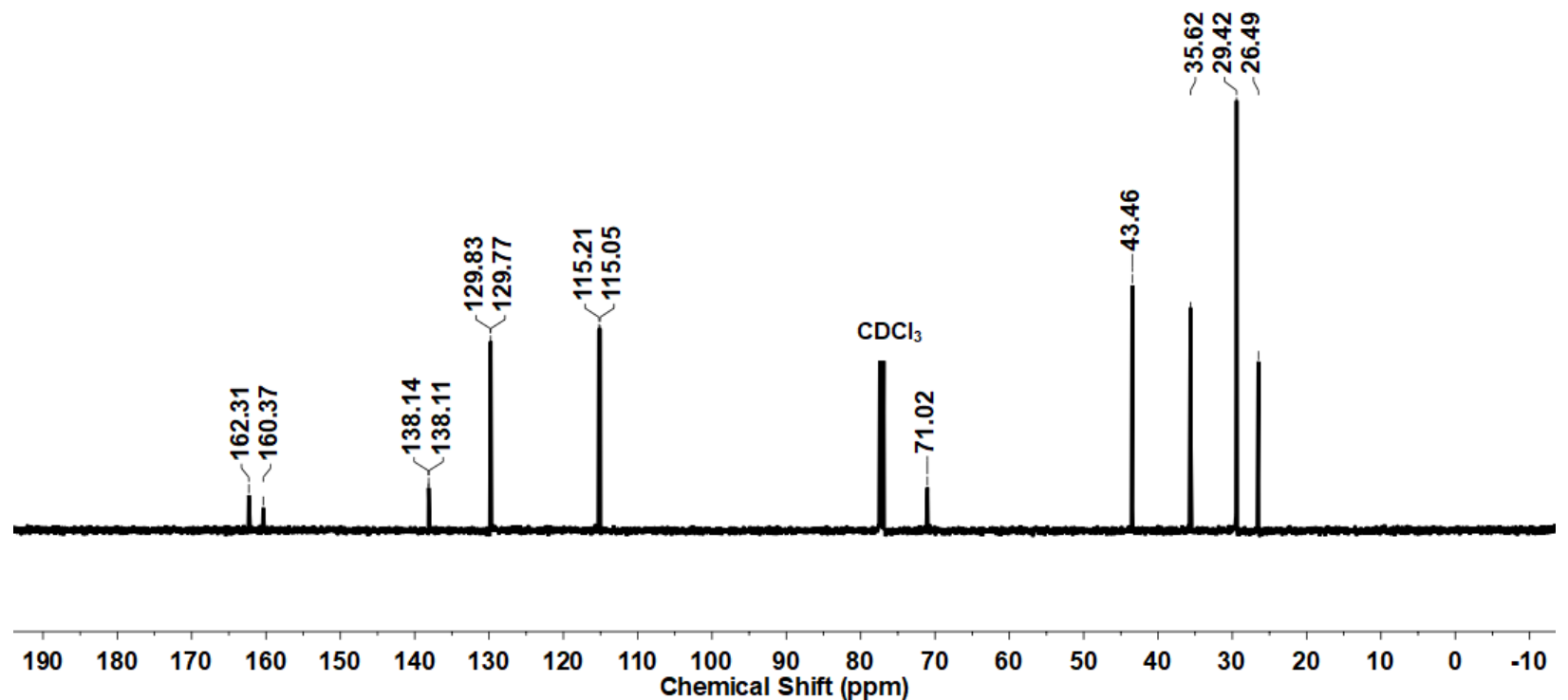

Figure S-40. $125 \mathrm{MHz}{ }^{13} \mathrm{C}\left\{{ }^{1} \mathrm{H}\right\}$ NMR spectrum of 5-(4-fluorophenyl)-2-methylpentan-2-ol in chloroform- $d$. 
<smiles>CC(C)(N)CCCc1ccc(F)cc1</smiles>

${ }^{1} \mathrm{H}$ NMR at $25^{\circ} \mathrm{C}$ in $\mathrm{CDCl}_{3}$

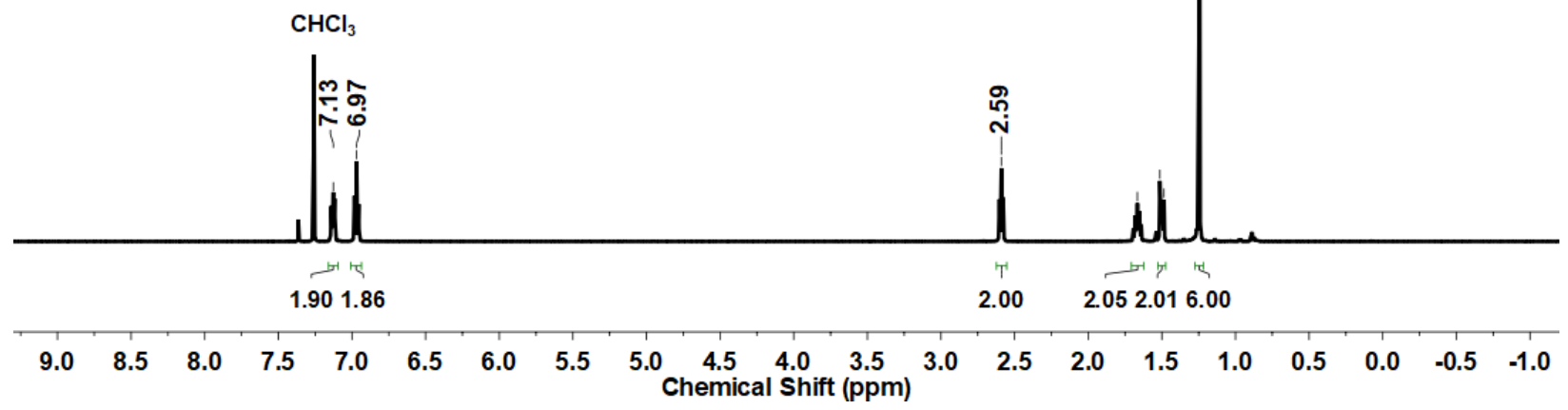

Figure S-41. $600 \mathrm{MHz}{ }^{1} \mathrm{H}$ NMR spectrum of 1-(4-azido-4-methylpentyl)-4-fluorobenzene in chloroform- $d$.
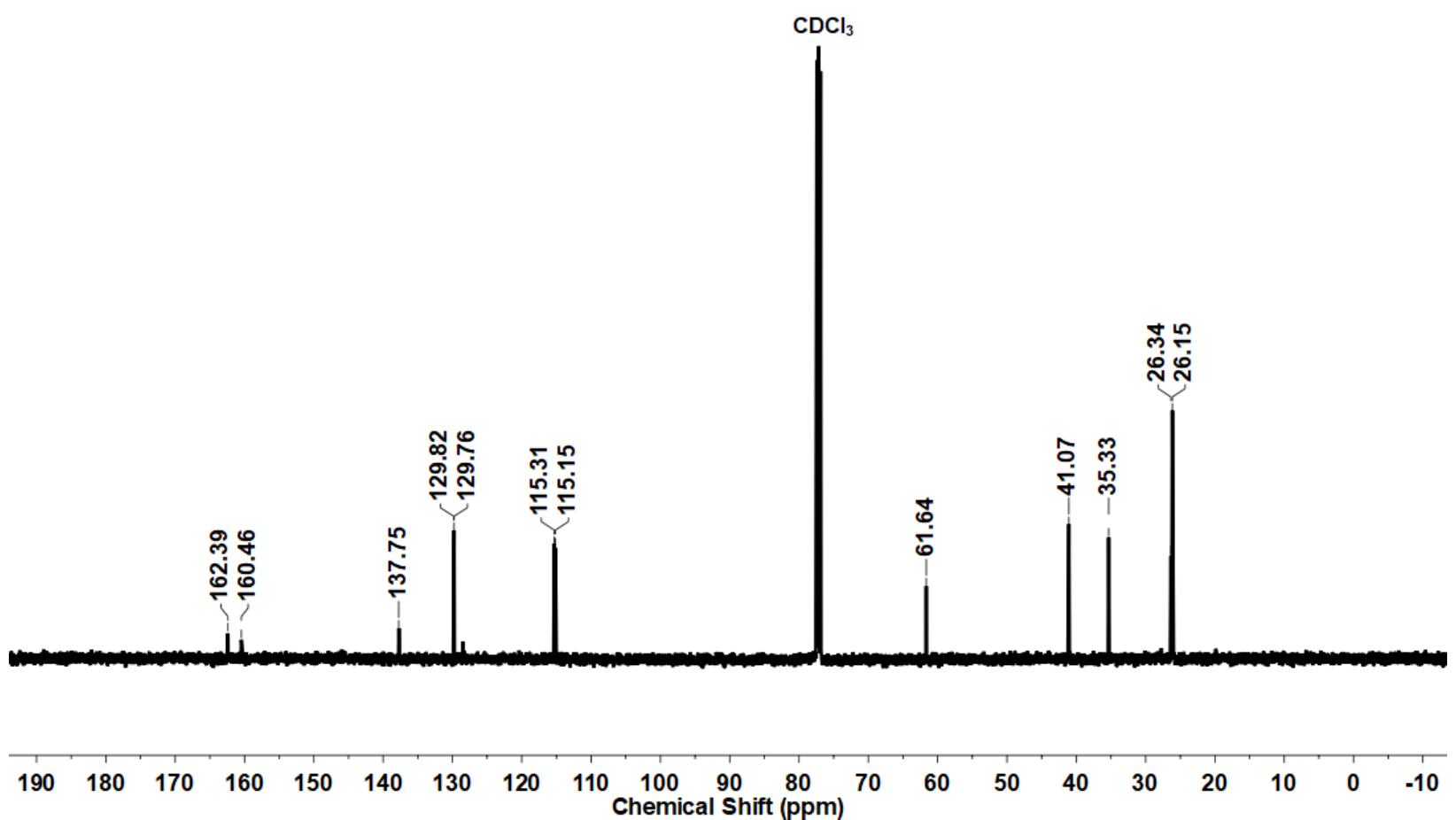

Figure S-42. $125 \mathrm{MHz}{ }^{13} \mathrm{C}\left\{{ }^{1} \mathrm{H}\right\}$ NMR spectrum of 1-(4-azido-4-methylpentyl)-4-fluorobenzene in chloroform- $d$. 


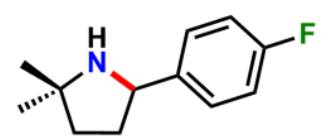

${ }^{1} \mathrm{H} \mathrm{NMR}$ at $25^{\circ} \mathrm{C}$ in $\mathrm{CDCl}_{3}$

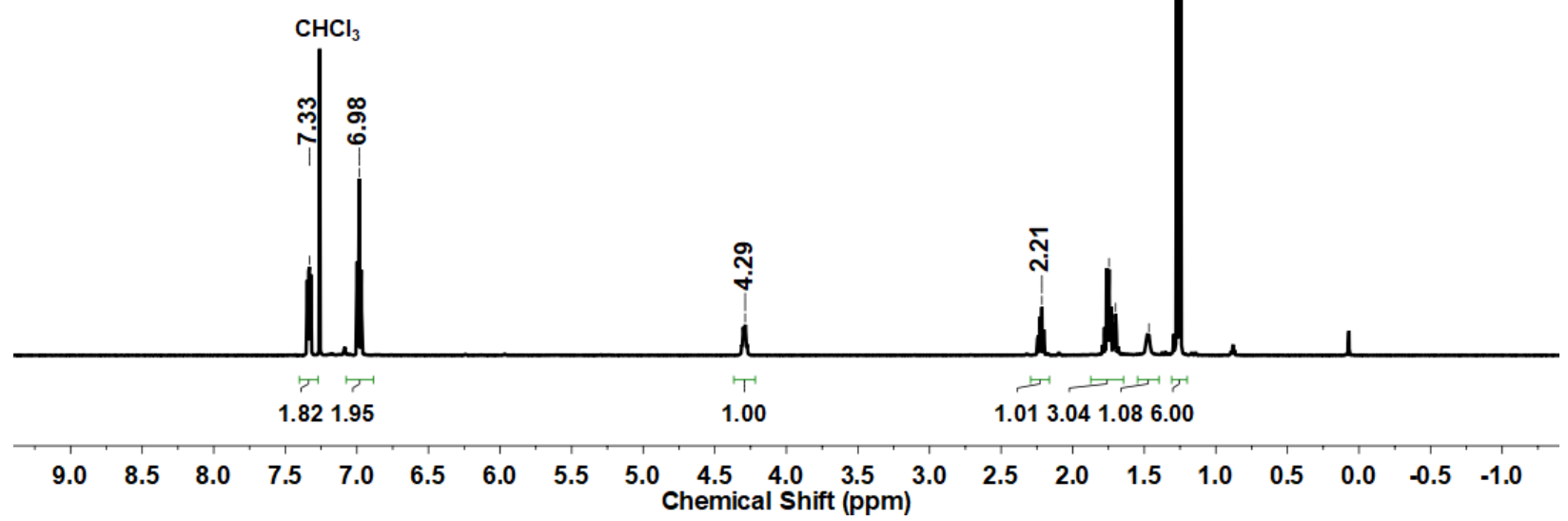

Figure S-43. $600 \mathrm{MHz}{ }^{1} \mathrm{H}$ NMR spectrum of 5-(4-fluorophenyl)-2,2-dimethylpyrrolidine in chloroform- $d$.
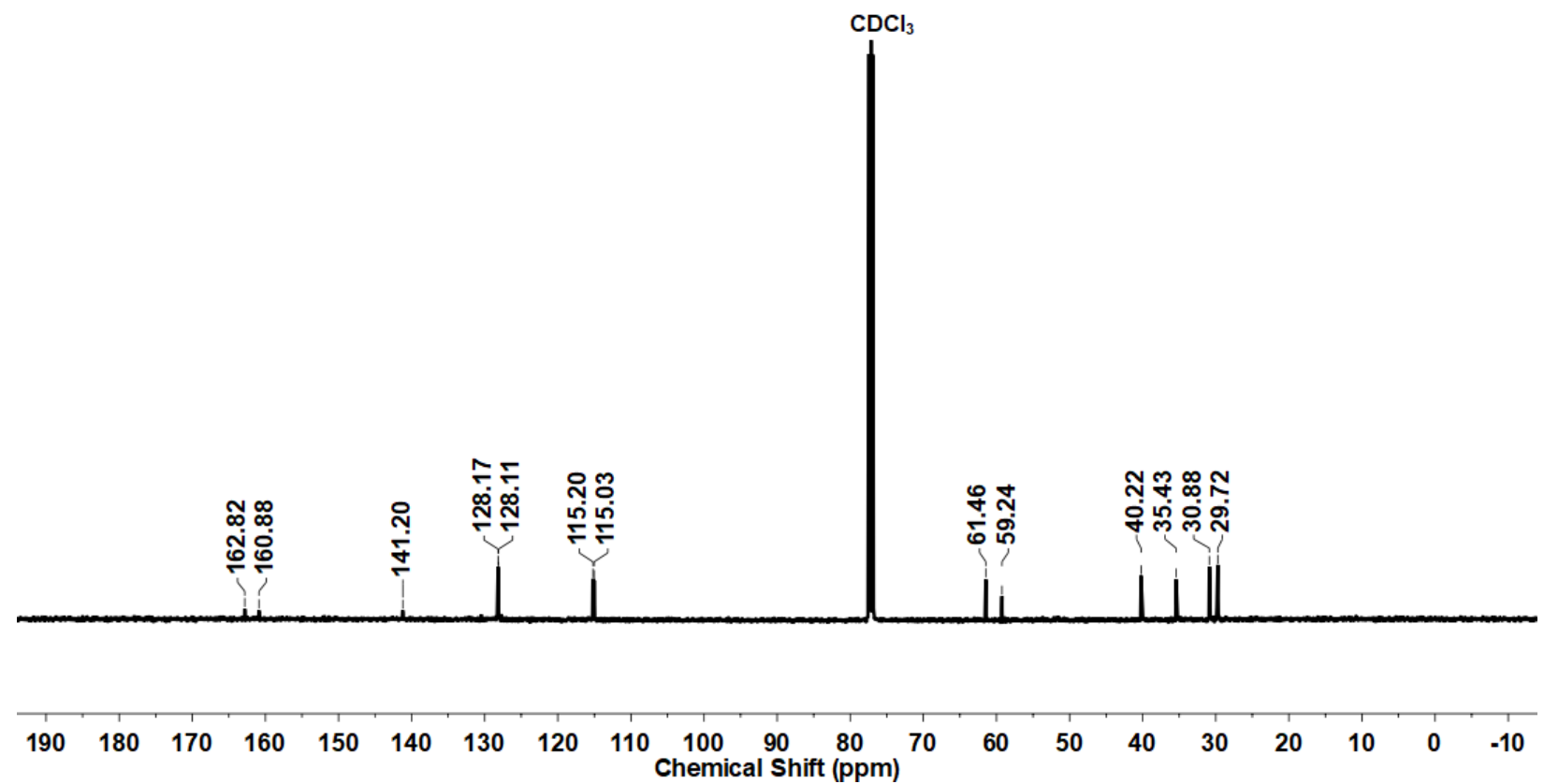

Figure S-44. $125 \mathrm{MHz}{ }^{13} \mathrm{C}\left\{{ }^{1} \mathrm{H}\right\}$ NMR spectrum of 5-(4-fluorophenyl)-2,2-dimethylpyrrolidine in chloroform- $d$. 


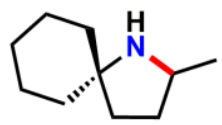

${ }^{1} \mathrm{H}$ NMR at $25^{\circ} \mathrm{C}$ in $\mathrm{CDCl}_{3}$

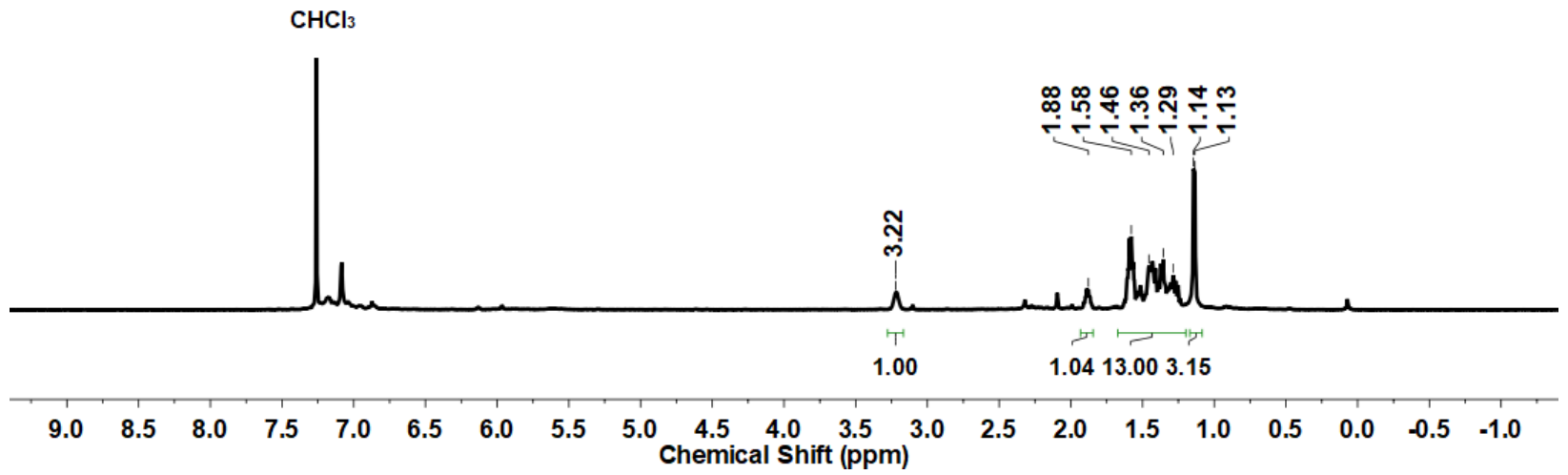

Figure S-45. $600 \mathrm{MHz}{ }^{1} \mathrm{H}$ NMR spectrum of 2-methyl-1-azaspiro[4.5]decane in chloroform- $d$.

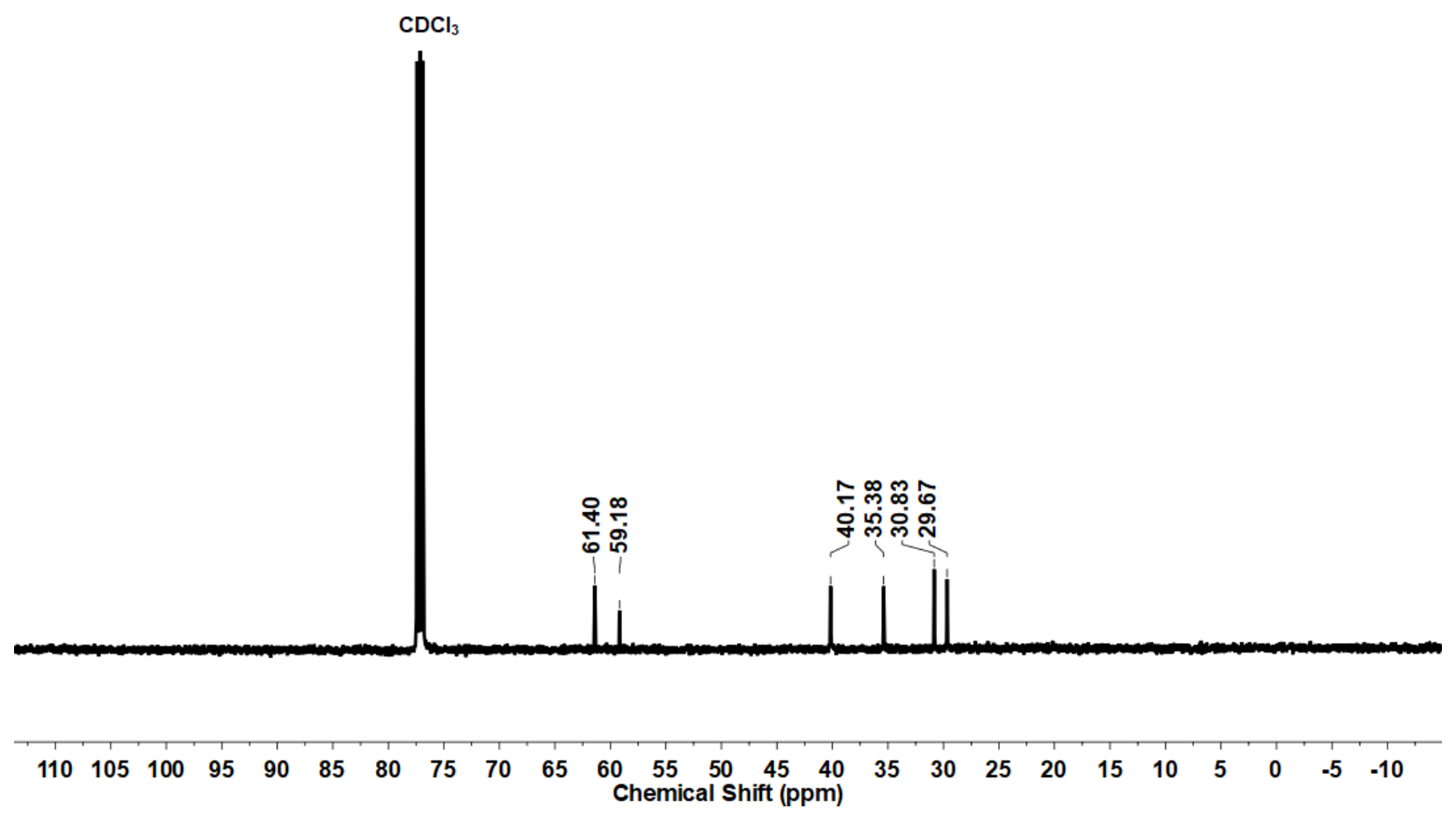

Figure S-46. $125 \mathrm{MHz}{ }^{13} \mathrm{C}\left\{{ }^{1} \mathrm{H}\right\}$ NMR spectrum of 2-methyl-1-azaspiro[4.5]decane in chloroform$d$. 


\section{X-Ray Diffraction Techniques.}

All structures were collected on a Bruker three-circle platform goniometer equipped with an Apex II CCD and an Oxford cryostream cooling device. Radiation was from a graphite fine focus sealed tube Mo K $\alpha(0.71073 \AA)$ source. Crystals were mounted on a cryoloop or glass fiber pin using Paratone N oil. Structures were collected at $100 \mathrm{~K}$. Data was collected as a series of $\varphi$ and/or $\omega$ scans. Data was integrated using SAINT $^{18}$ and scaled with either a numerical or multi-scan absorption correction using SADABS. ${ }^{18}$ The structures were solved by direct methods or Patterson maps using SHELXS-2014 ${ }^{19}$ and refined against $F^{2}$ on all data by full matrix least squares with SHELXL-2014. All non-hydrogen atoms were refined anisotropically. Hydrogen atoms were placed at idealized positions and refined using a riding model. The isotropic displacement parameters of all hydrogen atoms were fixed to 1.2 times the atoms they are linked to (1.5 times for methyl groups). Further details on particular structures are noted below.

$\left.{ }^{\operatorname{Tr}} \mathbf{L}\right) \mathbf{C o C l}(\mathbf{1})$. The structure was solved in the triclinic space group $P \overline{1}$ with 2 molecules per unit cell.

(Tr $\mathbf{L}) \mathbf{C o}(2)$. The structure was solved in the monoclinic space group $P 2_{1} / c$ with 4 molecules per unit cell.

$\left({ }^{\operatorname{Tr}} \mathbf{L}\right) \mathbf{C o}(\mathbf{N A d})(3)$. The structure was solved in the monoclinic space group $C 2 / c$ with 8 molecules per unit cell.

$\left({ }^{\operatorname{Tr}} \mathbf{L}\right) \mathbf{C o}(\mathbf{p y})$ (4). The structure was solved in the monoclinic space group $C 2 / c$ with 8 molecules per unit cell. One of the aryl rings from the ligand exhibited positional disorder and was refined using similarity constraints. 
Table S-8. X-ray diffraction experimental details $\mathrm{s}^{\mathrm{a}, \mathrm{b}}$

\begin{tabular}{|c|c|c|c|c|}
\hline & $\left({ }^{\operatorname{Tr}} \mathrm{L}\right) \mathrm{CoCl}(\mathbf{1})$ & $\left({ }^{\operatorname{Tr}} \mathrm{L}\right) \mathrm{Co}(2)$ & $\left({ }^{\operatorname{Tr}} \mathbf{L}\right) \operatorname{Co}(\mathbf{N A d})(3)$ & $\left({ }^{\operatorname{Tr}} \mathbf{L}\right) \operatorname{Copy}(4)$ \\
\hline CCDC & 1921803 & 1921804 & 1921805 & 1921806 \\
\hline $\begin{array}{c}\text { Moiety } \\
\text { Formula }\end{array}$ & $\mathrm{C}_{56} \mathrm{H}_{45} \mathrm{ClCoN}_{2}$ & $\begin{array}{c}\mathrm{C}_{56} \mathrm{H}_{45} \mathrm{CoN}_{2} \\
\left(2 * \mathrm{C}_{6} \mathrm{H}_{6}\right)\end{array}$ & $\mathrm{C}_{66} \mathrm{H}_{60} \mathrm{CoN}_{3}$ & $\mathrm{C}_{61} \mathrm{H}_{50} \mathrm{CoN}_{3}$ \\
\hline FW & 840.32 & 961.09 & 954.10 & 883.97 \\
\hline $\begin{array}{l}\text { Crystal } \\
\text { System }\end{array}$ & Triclinic & Monoclinic & Monoclinic & Monoclinic \\
\hline $\begin{array}{c}\text { Space } \\
\text { Group }(Z)\end{array}$ & $P \overline{1}(2))$ & $P 2{ }_{1} / c(4)$ & $C 2 / \mathrm{c}(8)$ & $C 2 / \mathrm{c}(8)$ \\
\hline $\mathbf{a}(\AA)$ & $10.1504(13)$ & $16.869(3)$ & 43.307(9) & $43.246(4)$ \\
\hline $\mathbf{b}(\AA)$ & $13.5086(17)$ & $16.388(3)$ & $11.775(3)$ & $9.1582(9)$ \\
\hline c $(\AA)$ & $20.683(3)$ & $18.054(3)$ & $23.012(5)$ & $30.563(3)$ \\
\hline$\alpha\left(^{\circ}\right)$ & $105.697(3)$ & 90 & 90 & 90 \\
\hline$\beta\left(^{\circ}\right)$ & $13.5086(17)$ & $92.260(4)$ & $121.668(4)$ & $117.576(3)$ \\
\hline$\gamma\left({ }^{\circ}\right)$ & $20.683(3)$ & 90 & 90 & 90 \\
\hline $\begin{array}{c}\text { Volume } \\
\left(\AA^{\mathbf{3}}\right)\end{array}$ & $2705.1(6)$ & 4987.1(15) & $9988(4)$ & $10729.5(18)$ \\
\hline $\begin{array}{c}\text { Calc. } \rho \\
\left(\mathrm{mg} / \mathbf{m}^{3}\right)\end{array}$ & 1.032 & 1.280 & 1.268 & 1.094 \\
\hline$\mu\left(\mathbf{m m}^{-1}\right)$ & 0.399 & 0.390 & 0.390 & 0.358 \\
\hline $\begin{array}{c}\text { Crystal } \\
\text { Size }(\mathbf{m m})\end{array}$ & $0.25 \times 0.12 \times 0.10$ & $0.30 \times 0.18 \times 0.15$ & $0.20 \times 0.15 \times 0.14$ & $0.54 \times 0.05 \times 0.04$ \\
\hline Reflections & 9458 & 8819 & 8688 & 9499 \\
\hline $\begin{array}{c}\text { Completen } \\
\text { ess (to } \theta)\end{array}$ & $\begin{array}{c}98.5 \% \\
25.092^{\circ}\end{array}$ & $\begin{array}{c}99.4 \% \\
25.107^{\circ}\end{array}$ & $\begin{array}{c}98.3 \% \\
25.050^{\circ}\end{array}$ & $\begin{array}{c}99.6 \% \\
25.078^{\circ}\end{array}$ \\
\hline GOF on $F^{2}$ & 1.059 & 1.006 & 1.012 & 1.151 \\
\hline $\begin{array}{l}\mathrm{R} 1, \mathrm{wR}^{\mathrm{c}} \\
{[\mathrm{I}>\mathbf{2 \sigma}(\mathrm{I})]}\end{array}$ & $0.0948,0.02621$ & $0.0583,0.1271$ & $0.0715,0.1207$ & $0.1941,0.4212$ \\
\hline
\end{tabular}

${ }^{\mathrm{a}} \lambda=0.71073 \AA ;{ }^{\mathrm{b}} \mathrm{T}=100(2) \mathrm{K} ;{ }^{\mathrm{c}} \mathrm{R} 1=\Sigma|| F_{o}|-| F_{\mathrm{c}} \| / \Sigma\left|F_{o}\right|, \mathrm{wR} 2=\left\{\Sigma\left[w\left(F_{o}{ }^{2}-F_{c}{ }^{2}\right)^{2}\right] / \Sigma\left[w\left(F_{o}{ }^{2}\right)^{2}\right]\right\}^{1 / 2}$ 


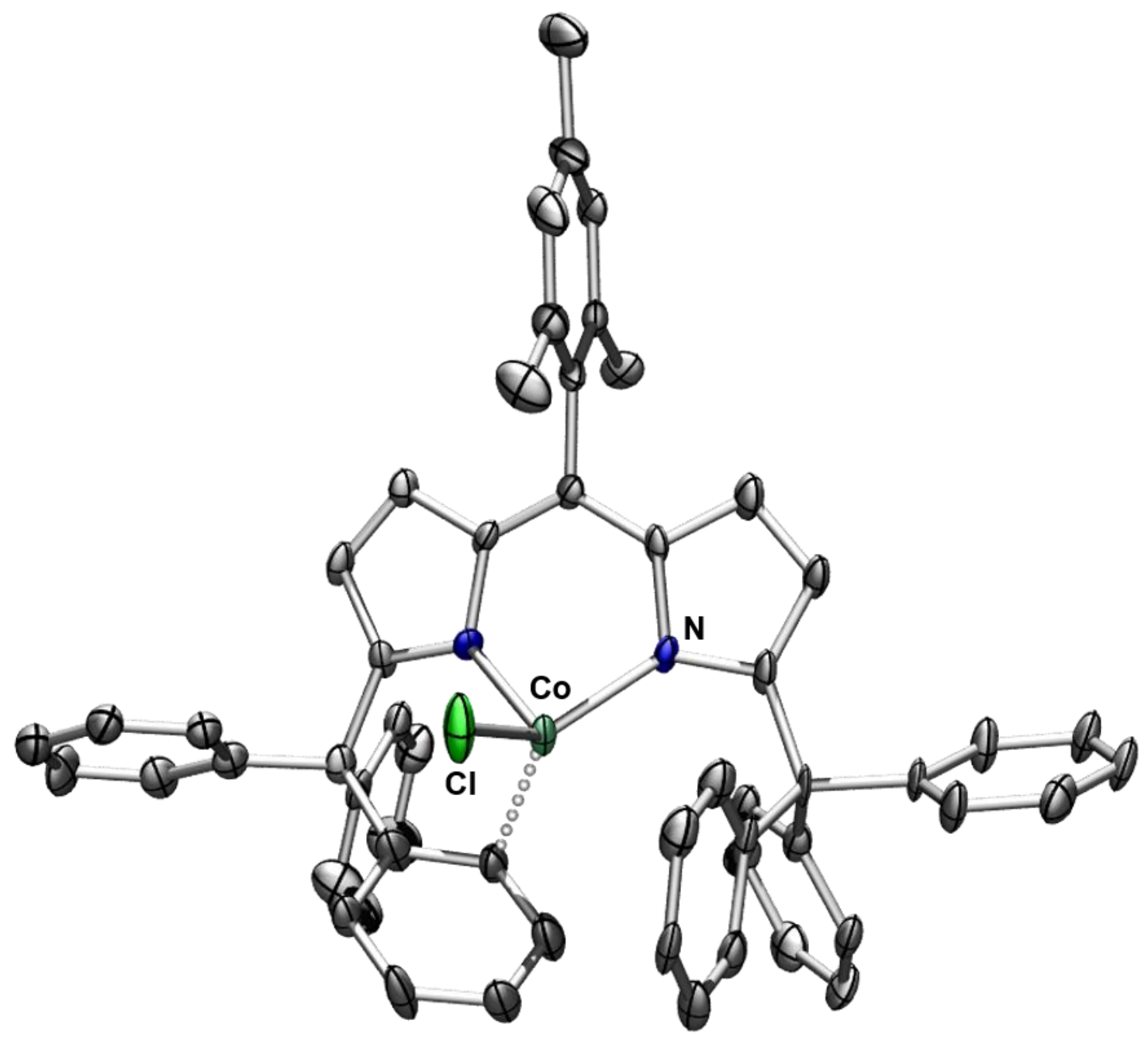

Figure S-47. Solid-state molecular structure for $\left({ }^{\mathrm{Tr}} \mathrm{L}\right) \mathrm{CoCl}(\mathbf{1})$ with thermal ellipsoids at $50 \%$ probability level. Hydrogens omitted for clarity. 


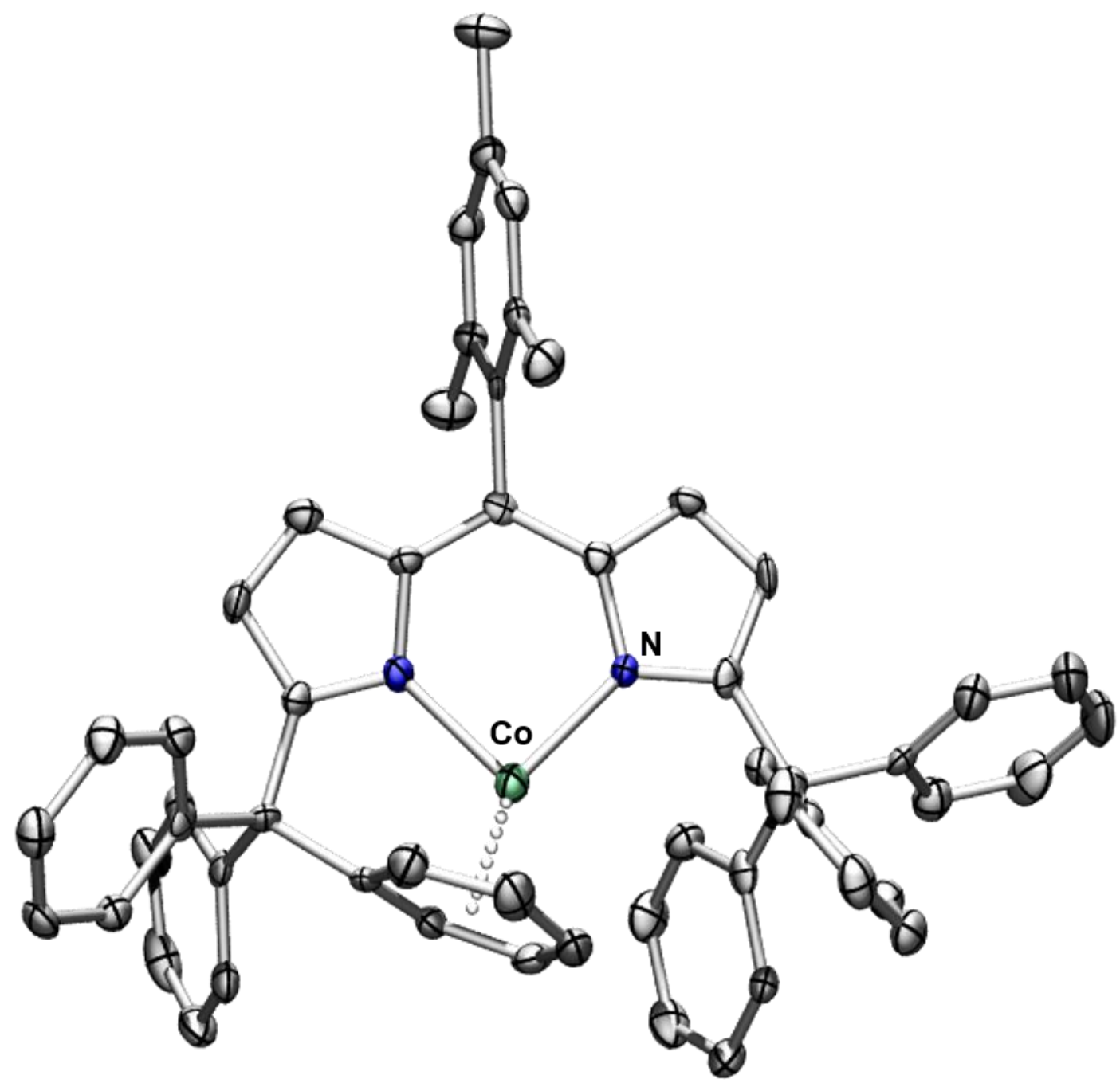

Figure S-48. Solid-state molecular structure for $\left({ }^{\mathrm{Tr}} \mathrm{L}\right)$ Co $(\mathbf{2})$ with thermal ellipsoids at $50 \%$ probability level. Hydrogens omitted for clarity. 


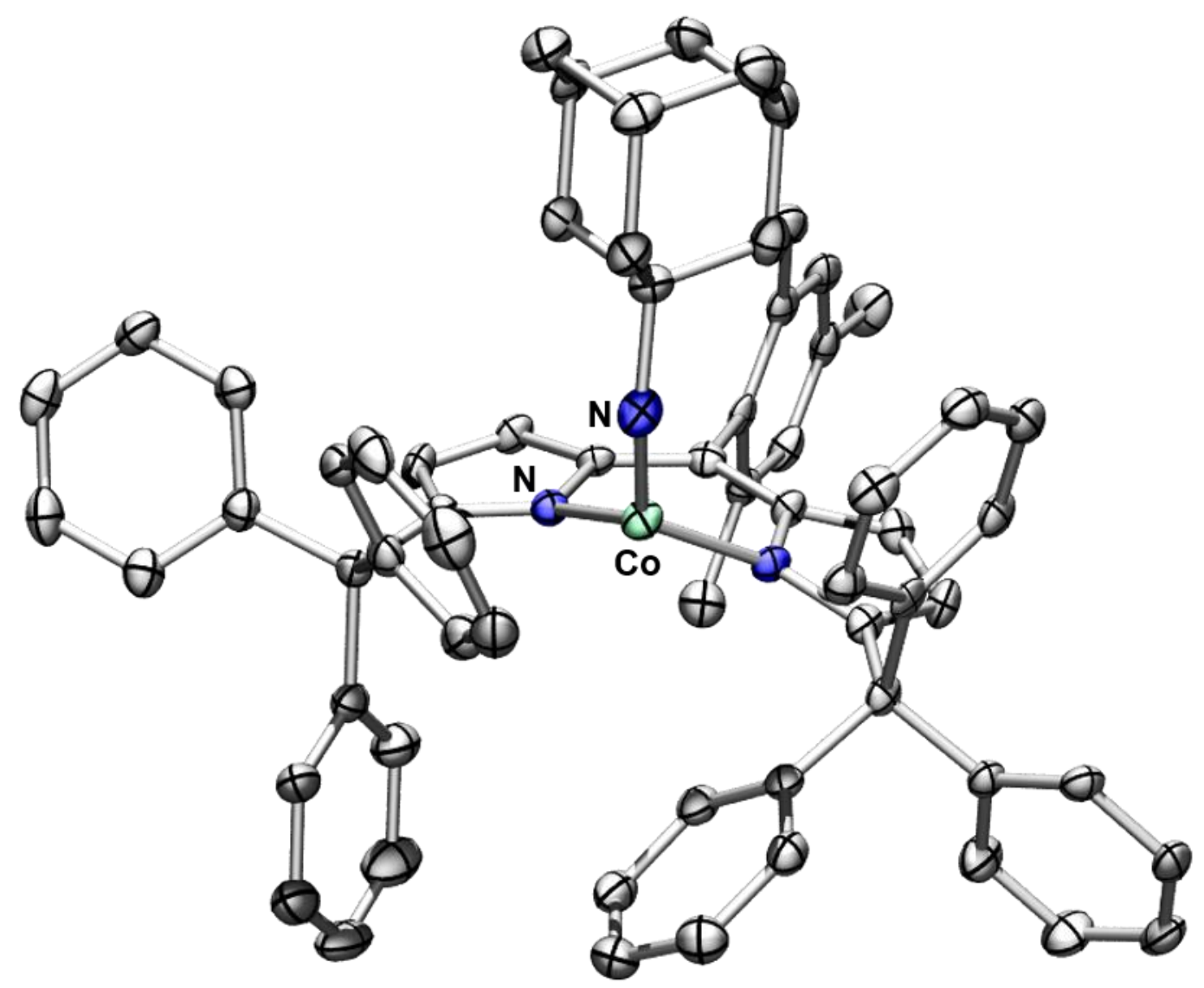

Figure S-49. Solid-state molecular structure for $\left({ }^{\operatorname{Tr}} \mathrm{L}\right) \mathrm{Co}(\mathrm{NAd})(3)$ with thermal ellipsoids at $50 \%$ probability level. Hydrogens omitted for clarity. 


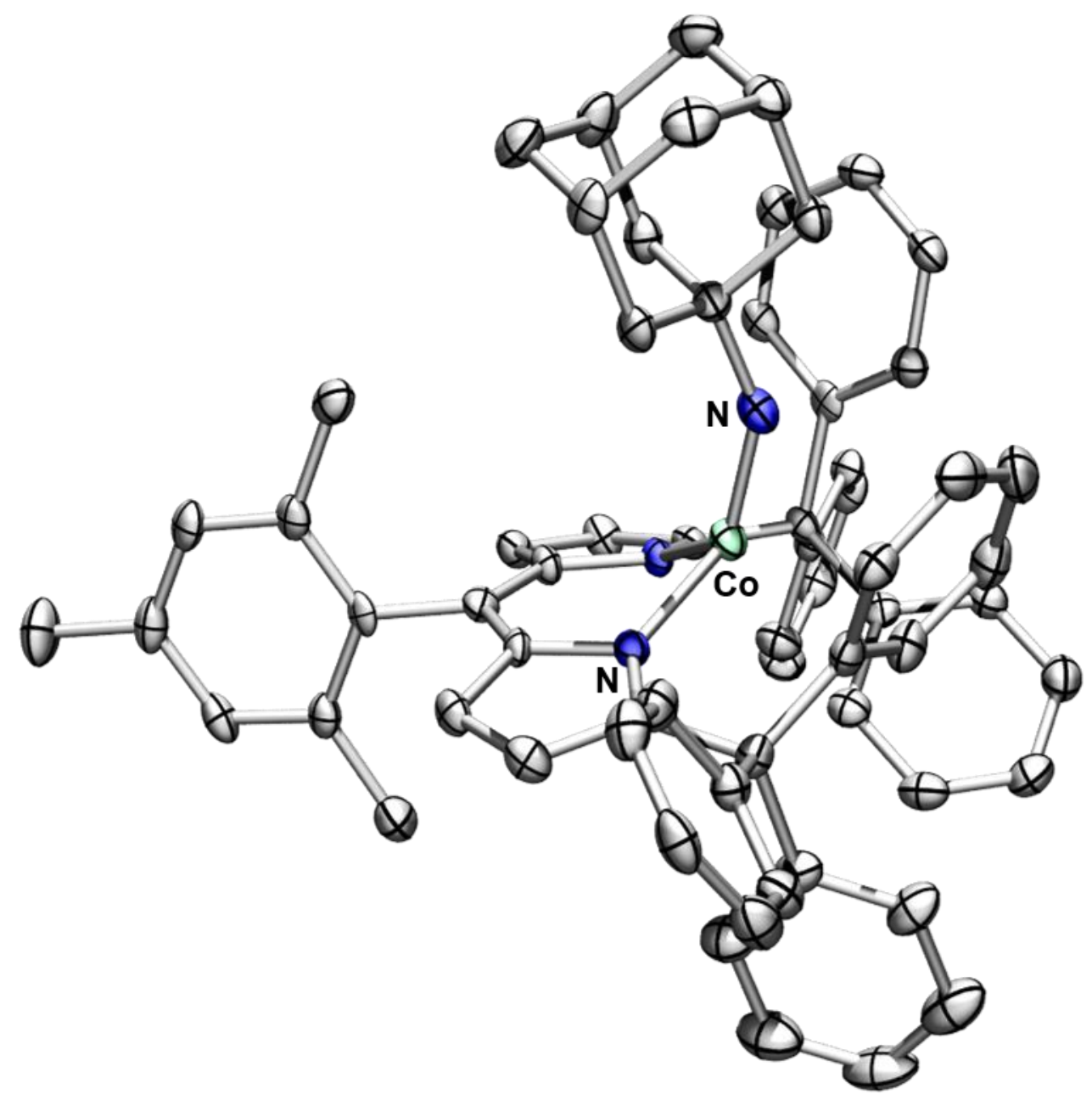

Figure S-50. Solid-state molecular structure for $\left({ }^{\mathrm{Tr}} \mathrm{L}\right) \mathrm{Co}(\mathrm{NAd})(3)$ with thermal ellipsoids at $50 \%$ probability level. Hydrogens omitted for clarity. 


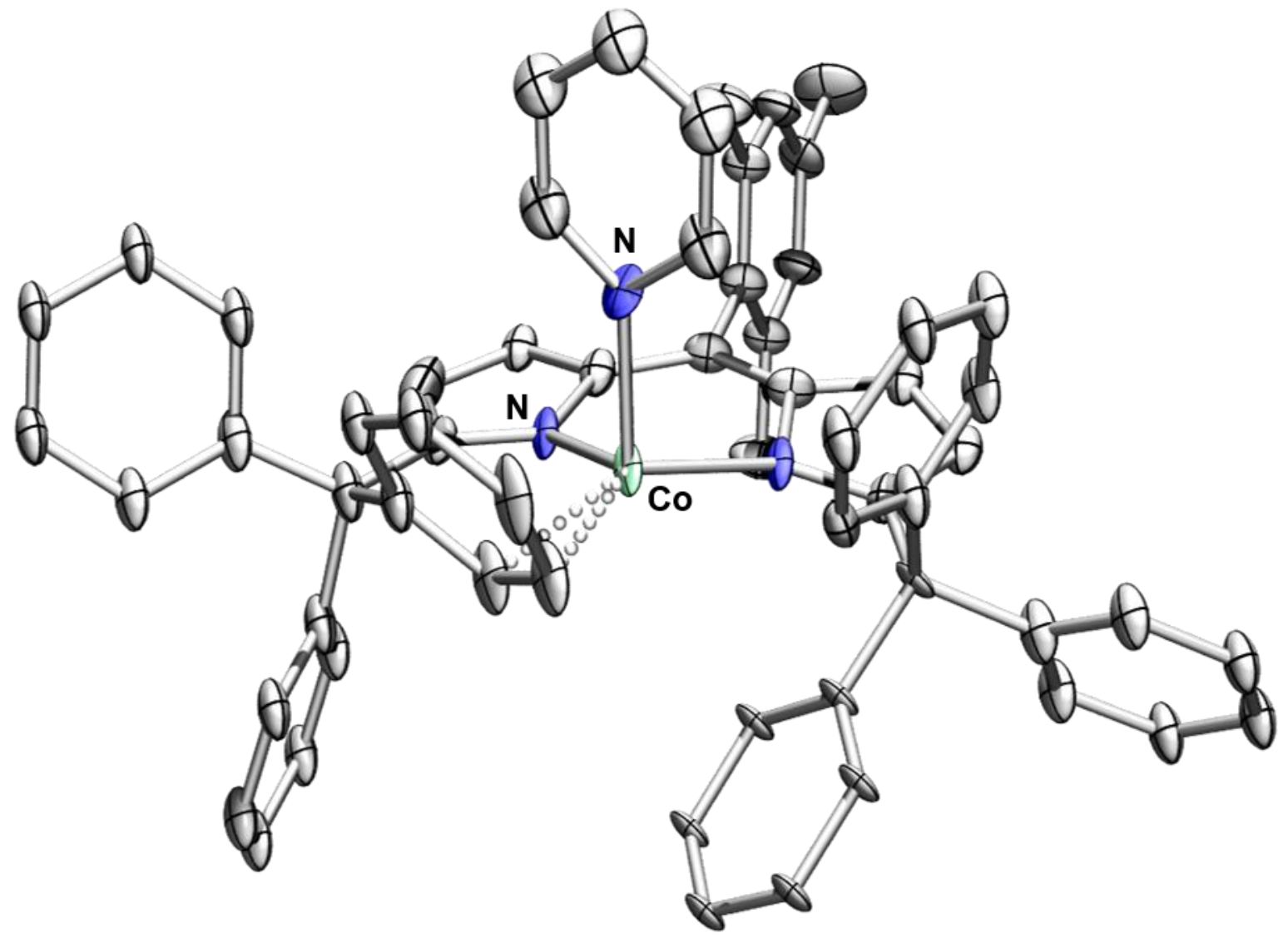

Figure S-51. Solid-state molecular structure for $\left({ }^{\mathrm{Tr}} \mathrm{L}\right) \mathrm{Co}(\mathrm{py})(\mathbf{4})$ with thermal ellipsoids at $50 \%$ probability level. Hydrogens omitted for clarity. 


\section{Computational Methods for Complex 3.}

Computations for FMO analysis were carried out utilizing the ORCA 4.0.1.2 program package. $^{20}$ The BP86 ${ }^{21}$ functional was chosen based on good agreement of the optimized structure of $\mathbf{3}$ with its crystallographic data at its spin ground state $(S=0)$, and used with def2-TZVP $22(\mathrm{Co}, \mathrm{N})$ and $\operatorname{def} 2-\mathrm{SV}(\mathrm{P})^{23}(\mathrm{C}, \mathrm{H})$ basis sets. Further, the def2-TSVP/J $(\mathrm{Co}, \mathrm{N})$ and def2-SV $(\mathrm{P}) / \mathrm{J}(\mathrm{C}, \mathrm{H})$ auxiliary basis sets were employed to utilize the RIJCOSX ${ }^{24}$ approximation for accelerating calculation. All geometries were taken from X-ray structures.

Table S-9. Summary of the geometry optimized results of $\left({ }^{\mathrm{Tr}} \mathrm{L}\right) \mathrm{Co}(\mathrm{NAd})(\mathbf{3})$.

\begin{tabular}{c|cccc} 
& $\begin{array}{c}\text { Crystallographic } \\
\text { data of } 3\end{array}$ & $S=0$ model & $S=1$ model & $S=2$ model \\
\hline $\mathrm{Co}-\mathrm{N}_{\text {imido }}(\AA)$ & $1.636(3)$ & 1.623 & 1.680 & 1.749 \\
$\mathrm{Co}-\mathrm{N}_{\text {dipyrrin }}(\AA)$ & $1.919(3) / 1.914(3)$ & $1.897 / 1.901$ & $1.934 / 1.971$ & $2.019 / 2.050$ \\
$\mathrm{Co}-\mathrm{C}_{\text {ortho }}(\AA)$ & 2.756 & 2.697 & 2.542 & 2.334 \\
$\angle \mathrm{Co}-\mathrm{N}_{\text {imido }}-\mathrm{C}$ & $145.0(3)$ & 144.335 & 146.123 & 174.099 \\
$\begin{array}{c}\left.{ }^{\circ}\right) \\
\text { Relative energy } \\
(\mathrm{kcal} / \mathrm{mol})\end{array}$ &. & 0 & & +8.777
\end{tabular}




\section{Computational Results.}

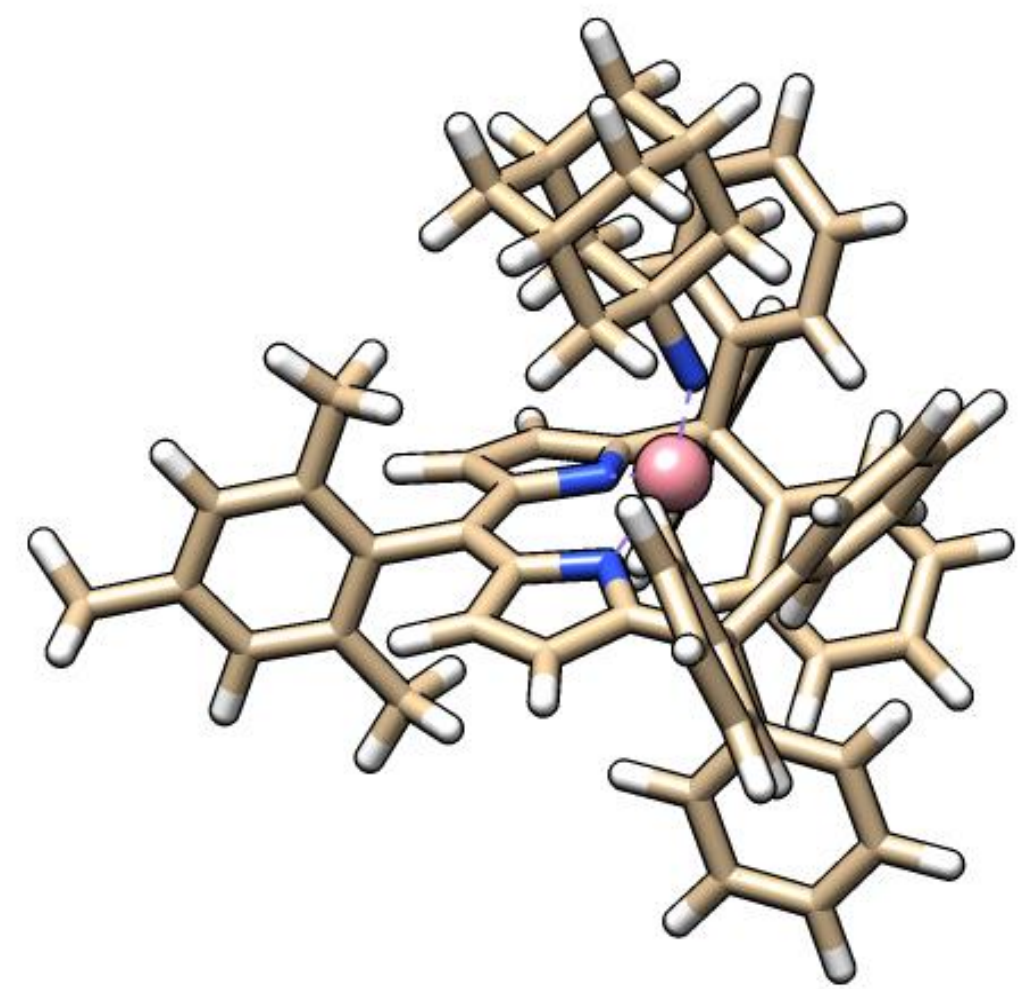

Figure S-52. Geometry optimized molecular structure of $\left({ }^{\mathrm{Tr}} \mathrm{L}\right) \mathrm{Co}(\mathrm{NAd})(\mathbf{3})$ with an $S=0$ spin state. 


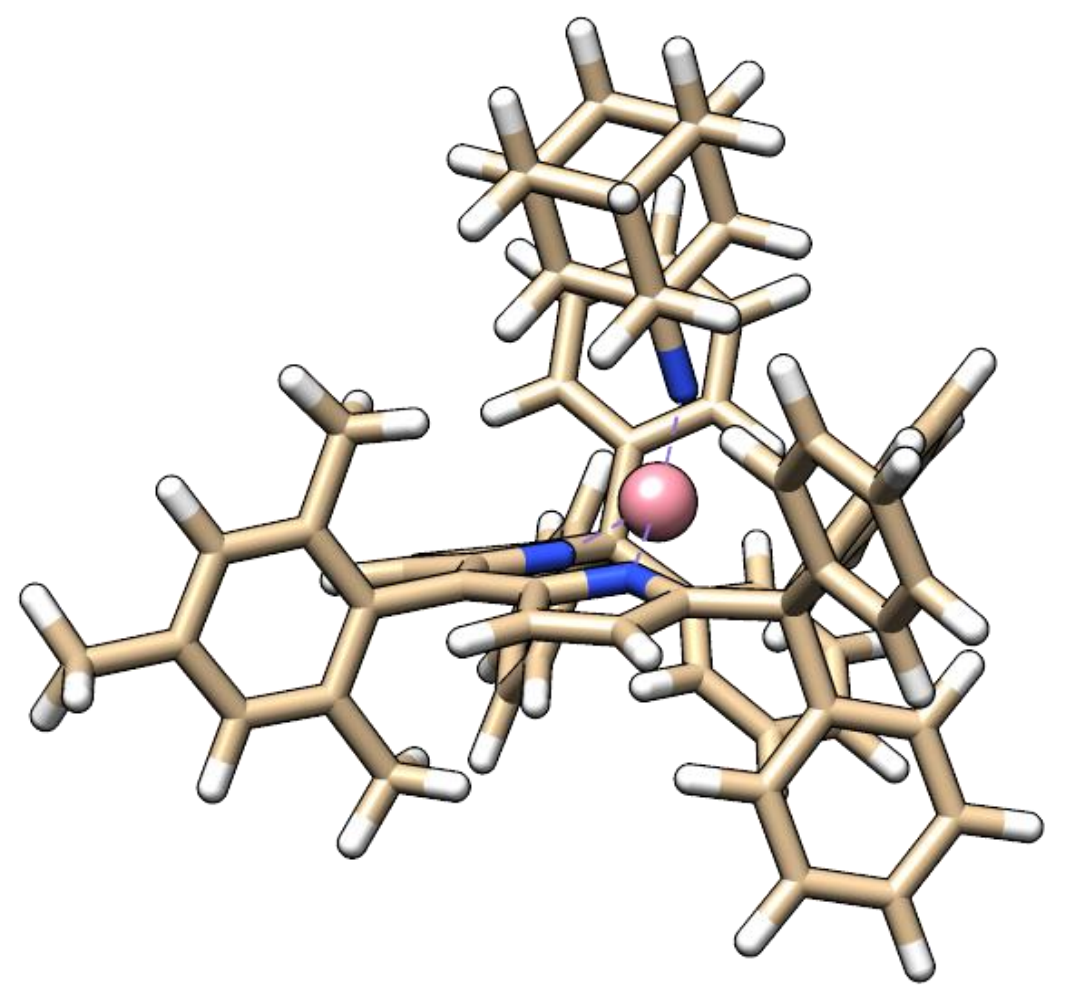

Figure S-53. Geometry optimized molecular structure of $\left({ }^{\mathrm{Tr}} \mathrm{L}\right) \mathrm{Co}(\mathrm{NAd})(3)$ with an $S=1$ spin state. 


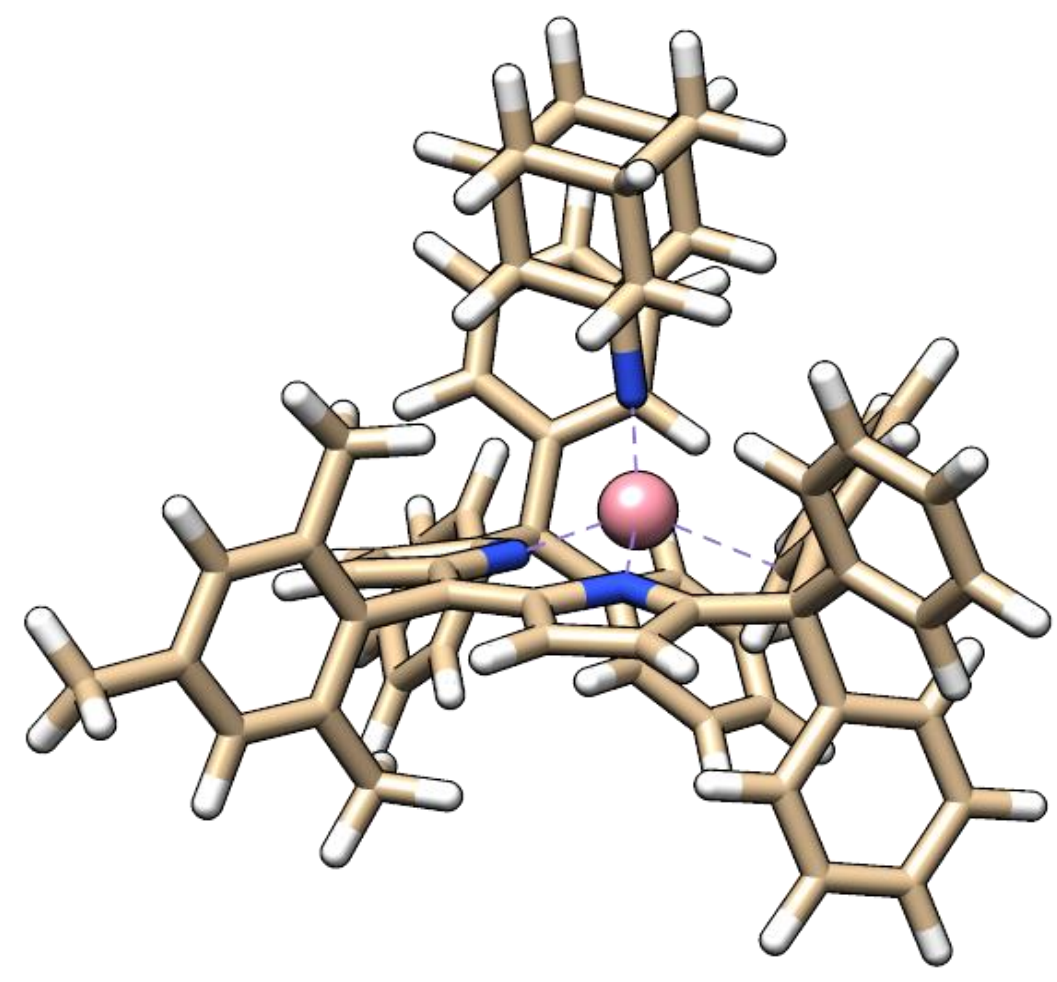

Figure S-54. Geometry optimized molecular structure of $\left({ }^{\mathrm{Tr}} \mathrm{L}\right) \mathrm{Co}(\mathrm{NAd})(3)$ with an $S=2$ spin state. 


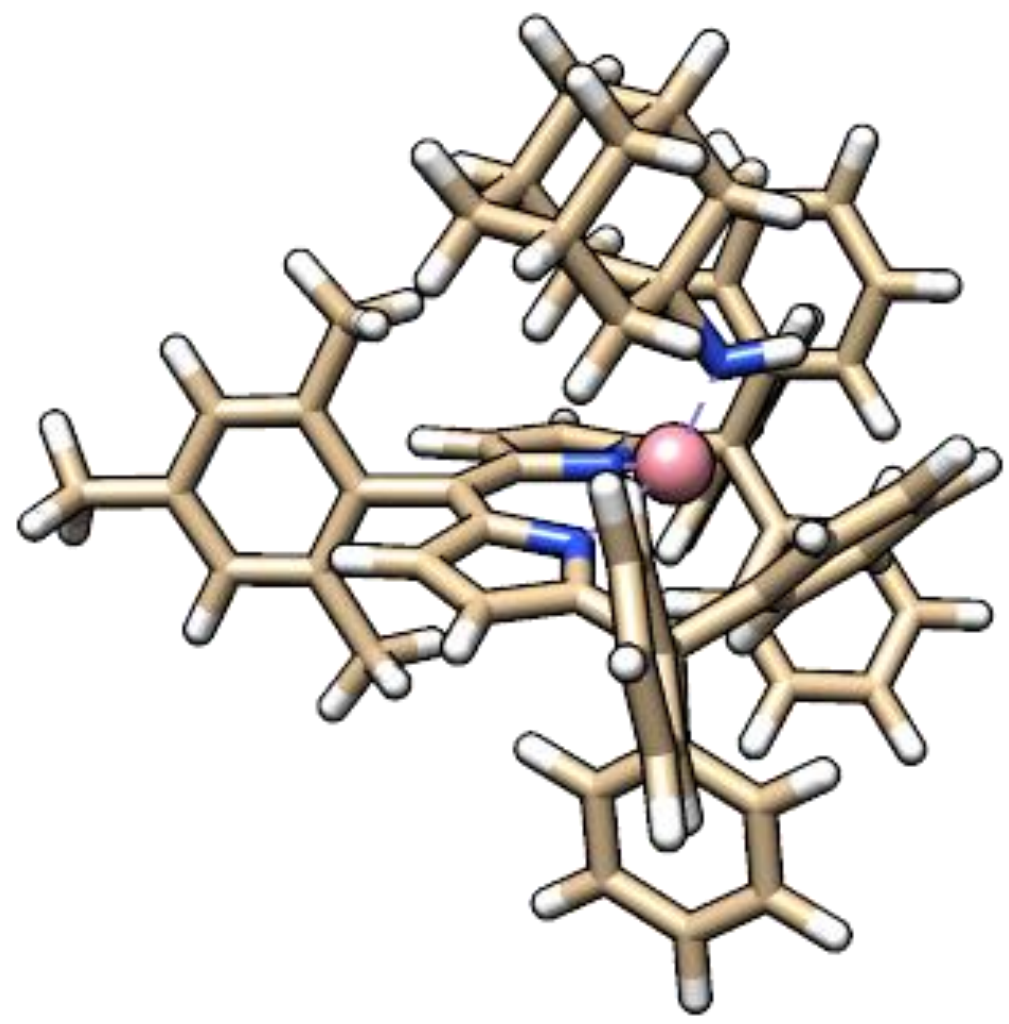

Figure S-55. Geometry optimized molecular structure of $\left({ }^{\mathrm{Tr}} \mathrm{L}\right) \mathrm{Co}(\mathrm{NHAd})(\mathbf{3 a})$. 


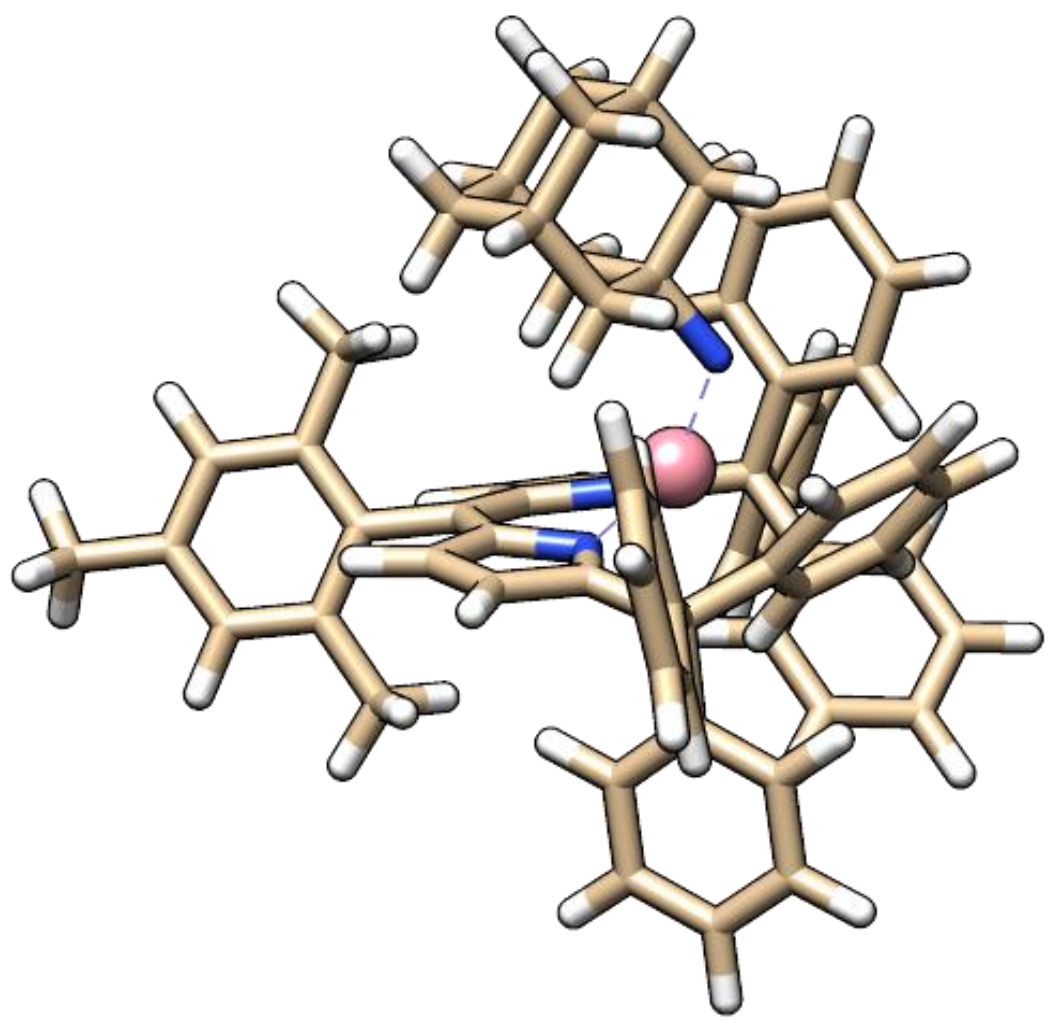

Figure S-56. Geometry optimized molecular structure of $\left[\left({ }^{\mathrm{Tr}} \mathrm{L}\right) \mathrm{Co}(\mathrm{NAd})\right]^{-}$. 


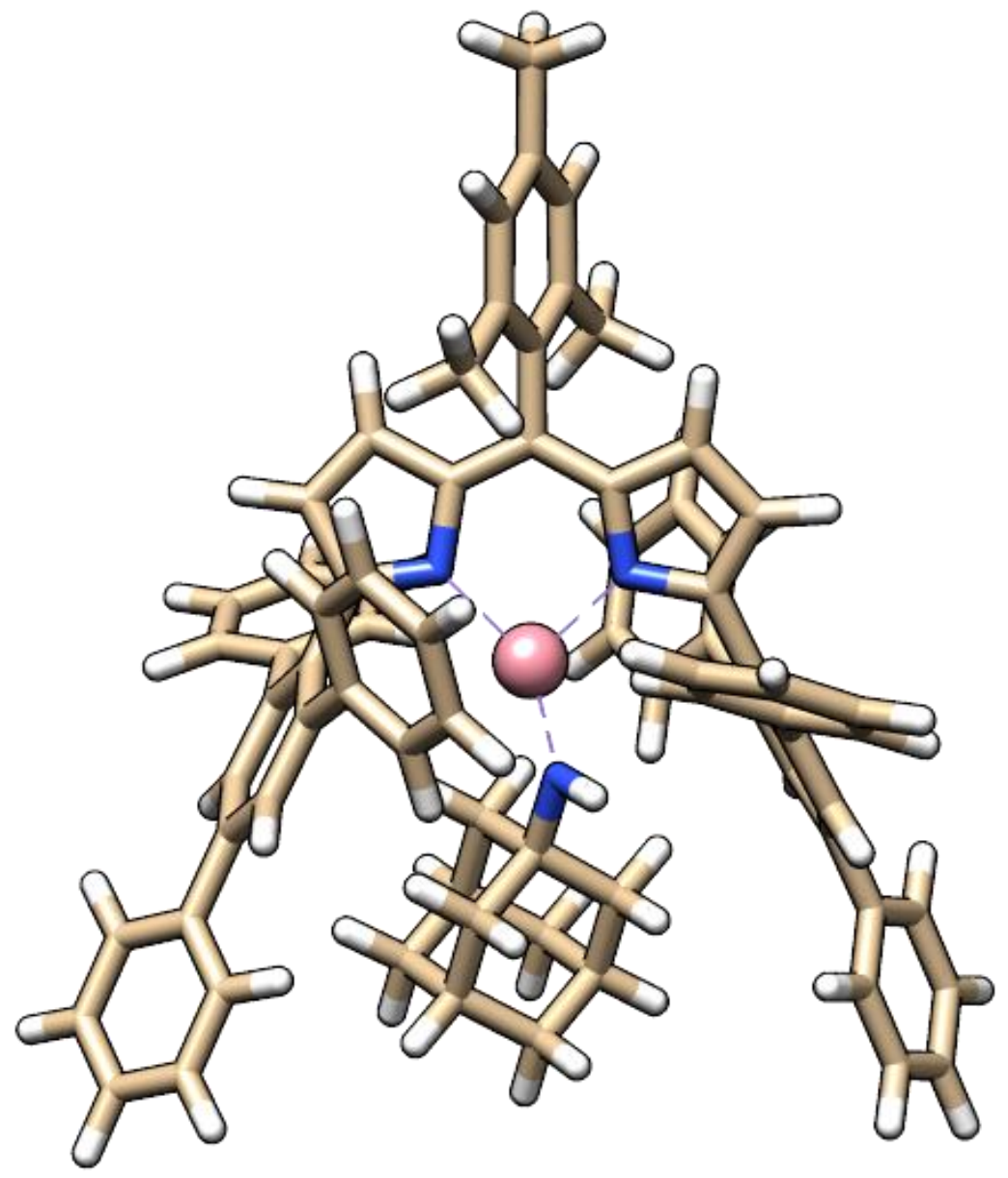

Figure S-57. Geometry optimized molecular structure of $\left({ }^{\mathrm{Ar}} \mathrm{L}\right) \mathrm{Co}(\mathrm{NHAd})(\mathbf{8 a})$. 


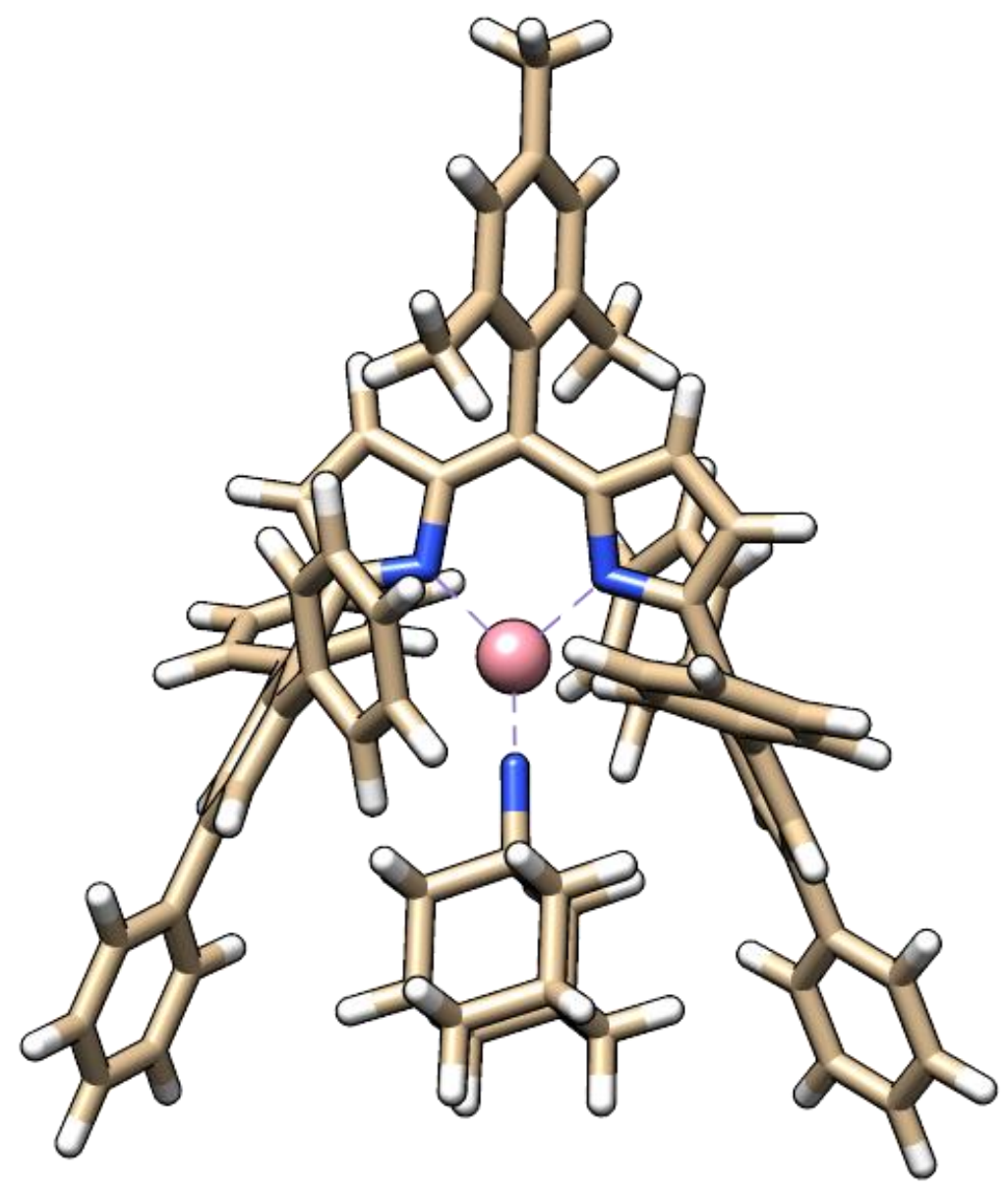

Figure S-58. Geometry optimized molecular structure of $\left[\left({ }^{\mathrm{Ar}} \mathrm{L}\right) \mathrm{Co}(\mathrm{NAd})\right]^{-}$. 
Table S-10. Coordinates of optimized molecular structure for $\left({ }^{\mathrm{Tr}} \mathrm{L}\right) \mathrm{Co}(\mathrm{NAd})(\mathbf{3})$.

$\begin{array}{lccr}\text { E }=-4096.566086931382 \text { a.u. } \\ \text { Charge }=0, \text { Spin } & \text { multiplicity }=1 \\ \text { Co } & 11.155776 & 3.742802 & 8.368610 \\ \text { N } & 9.441872 & 4.108238 & 9.095307 \\ \text { N } & 11.736077 & 5.547565 & 8.232683 \\ \text { N } & 12.104131 & 2.648233 & 9.101638 \\ \text { C } & 9.307832 & 5.189063 & 9.990907 \\ \text { C } & 12.699144 & 6.177111 & 7.495015 \\ \text { C } & 9.184709 & 9.512080 & 12.795070 \\ \text { C } & 14.057616 & 6.751623 & 5.429618 \\ \text { C } & 11.352071 & 6.440039 & 9.255154 \\ \text { C } & 9.862189 & 7.393438 & 11.017255 \\ \text { C } & 12.401930 & 4.999323 & 5.208573 \\ \text { C } & 8.300511 & 3.370861 & 9.182182 \\ \text { C } & 7.425385 & 3.944404 & 10.160867 \\ \text { H } & 6.437038 & 3.552463 & 10.428598 \\ \text { C } & 14.453661 & 4.593708 & 6.773824 \\ \text { C } & 15.372107 & 6.671420 & 4.925600 \\ \text { H } & 16.002977 & 5.802248 & 5.166124 \\ \text { C } & 11.014715 & 5.258371 & 5.241646 \\ \text { H } & 10.580693 & 5.804076 & 6.092887 \\ \text { C } & 7.702766 & 0.822513 & 10.481681 \\ \text { H } & 8.689811 & 1.229619 & 10.755880 \\ \text { C } & 9.134044 & 1.455967 & 7.679390 \\ \text { C } & 9.546723 & 0.153987 & 8.019559 \\ \text { H } & 9.013623 & -0.409240 & 8.799138 \\ \text { C } & 12.750120 & 2.310198 & 10.328229 \\ \text { C } & 16.501397 & 2.866302 & 7.737872 \\ \text { H } & 17.303791 & 2.198801 & 8.095259 \\ \text { C } & 13.775952 & 3.396439 & 10.766947 \\ \text { H } & 13.235779 & 4.357896 & 10.922483 \\ \text { H } & 14.509404 & 3.559937 & 9.947225 \\ \text { C } & 10.171212 & 4.848982 & 4.190770 \\ \text { H } & 9.092116 & 5.070026 & 4.246173 \\ \text { C } & 8.054419 & 5.073530 & 10.672278 \\ \text { H } & 7.675627 & 5.773418 & 11.428478 \\ \text { C } & 7.119771 & 1.196897 & 9.246686 \\ \text { C } & 10.212072 & 6.271892 & 10.073566 \\ \text { C } & 8.694779 & 9.485082 & 11.474479 \\ \text { H } & 8.038997 & 10.302744 & 11.125497 \\ \text { C } & 11.712218 & 2.097597 & 11.472608 \\ \text { H } & 11.137992 & 3.039767 & 11.620961 \\ \text { H } & 10.986525 & 1.316198 & 11.153519\end{array}$




\begin{tabular}{|c|c|c|c|}
\hline & & & \\
\hline & & & \\
\hline & & 8.447662 & 10.576641 \\
\hline & 16.535850 & 4.242270 & \\
\hline & 17.362386 & 4.662252 & \\
\hline & 12.170270 & 7.610595 & 2412 \\
\hline & 12.098755 & 8.478425 & \\
\hline & & & \\
\hline & & 1.274900 & \\
\hline & 14.4 & 3.206691 & \\
\hline & & & \\
\hline & $10.3^{\circ}$ & 7.40 & 12.3 \\
\hline & & 0.96 & \\
\hline & 12.7 & 7406 & 9. \\
\hline & & & \\
\hline & 13.0 & & \\
\hline & & 8.16 & \\
\hline & & & \\
\hline & & & \\
\hline & & & \\
\hline & & & \\
\hline & & & \\
\hline & & & \\
\hline & & & \\
\hline & & & \\
\hline & & 1.67 & 12.7 \\
\hline & & & \\
\hline & & & \\
\hline & & & \\
\hline & & & \\
\hline & 15.9 & 7.6 & 684 \\
\hline & & 7842 & \\
\hline & 333 & 6.30 & 12.8 \\
\hline & & & \\
\hline & & 6.40 & 13. \\
\hline & & 6.32 & 12. \\
\hline & & & \\
\hline & 15.539818 & 9.609733 & 8880 \\
\hline & & -0.560476 & \\
\hline & 5.256714 & -1.239507 & 11.738142 \\
\hline & 13.805781 & 8.895122 & \\
\hline & & 9.760827 & 3.994730 \\
\hline & & 10.621526 & 13.746908 \\
\hline & & 11.608113 & 13.233706 \\
\hline & 9.501104 & 10.702373 & 14.599440 \\
\hline & 7.778769 & 10.444037 & 14.177029 \\
\hline
\end{tabular}




$\begin{array}{crcr}\mathrm{C} & 7.047450 & -0.047485 & 11.365549 \\ \mathrm{H} & 7.529790 & -0.321815 & 12.318881 \\ \mathrm{C} & 10.625175 & -0.462745 & 7.354203 \\ \mathrm{H} & 10.918832 & -1.487497 & 7.637999 \\ \mathrm{C} & 9.843681 & 2.128450 & 6.651760 \\ \mathrm{H} & 9.483675 & 3.104011 & 6.289387 \\ \mathrm{C} & 14.221644 & 0.535778 & 11.410226 \\ \mathrm{H} & 14.757701 & -0.424092 & 11.226412 \\ \mathrm{C} & 6.429568 & 3.929103 & 7.067671 \\ \mathrm{H} & 6.623871 & 4.652898 & 7.874421 \\ \mathrm{C} & 6.724603 & 1.746240 & 6.067519 \\ \mathrm{H} & 7.170662 & 0.738565 & 6.081932 \\ \mathrm{C} & 10.695125 & 4.162780 & 3.084313 \\ \mathrm{H} & 10.033621 & 3.835920 & 2.264759 \\ \mathrm{C} & 12.078087 & 3.910015 & 3.028506 \\ \mathrm{H} & 12.512526 & 3.390875 & 2.157124 \\ \mathrm{C} & 8.460530 & 8.467968 & 9.167422 \\ \mathrm{H} & 9.275526 & 8.438121 & 8.409415 \\ \mathrm{H} & 7.856265 & 9.383303 & 8.987510 \\ \mathrm{H} & 7.811910 & 7.584278 & 8.972360 \\ \mathrm{C} & 5.180205 & -0.188261 & 9.829168 \\ \mathrm{H} & 4.180317 & -0.570004 & 9.563474 \\ \mathrm{C} & 13.179514 & 0.342007 & 12.534715 \\ \mathrm{H} & 12.458100 & -0.459631 & 12.253452 \\ \mathrm{H} & 13.684192 & 0.011794 & 13.472350 \\ \mathrm{C} & 10.888925 & 1.495209 & 5.953292 \\ \mathrm{H} & 11.371811 & 2.026384 & 5.117138 \\ \mathrm{C} & 13.442287 & 2.764938 & 13.190743 \\ \mathrm{H} & 13.948657 & 2.473213 & 14.140323 \\ \mathrm{H} & 12.910347 & 3.724183 & 13.389334 \\ \mathrm{C} & 5.611944 & 4.311379 & 5.986035 \\ \mathrm{H} & 5.184885 & 5.328267 & 5.963536 \\ \mathrm{C} & 11.293537 & 0.199948 & 6.312104 \\ \mathrm{H} & 12.115477 & -0.298385 & 5.770857 \\ \mathrm{C} & 14.487153 & 2.957505 & 12.067809 \\ \mathrm{H} & 15.214942 & 3.747017 & 12.364664 \\ \mathrm{C} & 5.341348 & 3.409554 & 4.945170 \\ \mathrm{H} & 4.700776 & 3.708589 & 4.098120 \\ \mathrm{H} & 15.234862 & 1.626524 & 11.827149 \\ \mathrm{H} & 15.772109 & 1.314572 & 12.753803 \\ \mathrm{H} & & & \\ \mathrm{H} & 5.902719 & 2.120242 & 4.992976 \\ \mathrm{H} & 1.398386 & 4.182208\end{array}$

Table S-11. Coordinates of optimized molecular structure for $\left({ }^{\mathrm{Tr}} \mathrm{L}\right) \mathrm{Co}(\mathrm{NAd})(\mathbf{3})$. 


$\begin{array}{lccr}\text { E }=-4096.5582167866 \text { a.u. } \\ \text { Charge }=0, \text { Spin } & \text { multiplicity }=3 \\ \text { Co } & 11.165563 & 3.767439 & 8.431341 \\ \text { N } & 9.401321 & 4.188555 & 9.103649 \\ \text { N } & 11.660924 & 5.645511 & 8.095308 \\ \text { N } & 12.163281 & 2.616873 & 9.141123 \\ \text { C } & 9.265630 & 5.301917 & 9.954526 \\ \text { C } & 12.634394 & 6.269287 & 7.366545 \\ \text { C } & 9.267183 & 9.618287 & 12.750069 \\ \text { C } & 14.065382 & 6.800365 & 5.341220 \\ \text { C } & 11.282265 & 6.546275 & 9.117944 \\ \text { C } & 9.862407 & 7.507938 & 10.935211 \\ \text { C } & 12.405034 & 5.049745 & 5.092310 \\ \text { C } & 8.272685 & 3.448797 & 9.233203 \\ \text { C } & 7.401451 & 4.044103 & 10.203956 \\ \text { H } & 6.421746 & 3.649064 & 10.499542 \\ \text { C } & 14.405268 & 4.667468 & 6.732275 \\ \text { C } & 15.407268 & 6.719931 & 4.916754 \\ \text { H } & 16.029285 & 5.862591 & 5.215982 \\ \text { C } & 11.011311 & 5.270878 & 5.105650 \\ \text { H } & 10.554241 & 5.807783 & 5.950156 \\ \text { C } & 7.820408 & 0.901475 & 10.594804 \\ \text { H } & 8.780507 & 1.377215 & 10.852060 \\ \text { C } & 9.176080 & 1.583374 & 7.759587 \\ \text { C } & 9.613632 & 0.271158 & 8.021254 \\ \text { H } & 9.091347 & -0.343727 & 8.769083 \\ \text { C } & 12.761134 & 2.153777 & 10.346298 \\ \text { C } & 16.427800 & 2.970734 & 7.803831 \\ \text { H } & 17.218899 & 2.315791 & 8.206500 \\ \text { C } & 13.661615 & 3.251195 & 10.996920 \\ \text { H } & 13.040165 & 4.155641 & 11.187175 \\ \text { H } & 14.452963 & 3.542428 & 10.271553 \\ \text { C } & 10.192778 & 4.823024 & 4.050881 \\ \text { H } & 9.106739 & 5.011743 & 4.091422 \\ \text { C } & 8.023915 & 5.198652 & 10.663642 \\ \text { H } & 7.648796 & 5.922952 & 11.398151 \\ \text { C } & 7.201767 & 1.214042 & 9.360687 \\ \text { C } & 10.168853 & 6.384432 & 9.979546 \\ \text { C } & 8.758114 & 9.622742 & 11.436140 \\ \text { H } & 8.119166 & 10.461851 & 11.107587 \\ \text { C } & 11.644831 & 1.767471 & 11.370519 \\ \text { H } & 11.007349 & 2.661012 & 11.560058 \\ \text { H } & 10.999810 & 0.984424 & 10.911107 \\ \text { C } & 10.085672 & 8.539286 & 13.132815 \\ \text { H } & 10.503010 & 8.514381 & 14.154908 \\ & & & \end{array}$




$\begin{array}{cccr}\mathrm{C} & 9.036962 & 8.589468 & 10.520328 \\ \mathrm{C} & 16.400799 & 4.339414 & 8.130488 \\ \mathrm{H} & 17.168771 & 4.766540 & 8.798135 \\ \mathrm{C} & 12.100100 & 7.714538 & 9.038706 \\ \mathrm{H} & 12.037813 & 8.581475 & 9.708778 \\ \mathrm{C} & 15.425954 & 2.449716 & 6.971921 \\ \mathrm{H} & 15.414315 & 1.375751 & 6.721295 \\ \mathrm{C} & 14.420638 & 3.287397 & 6.452552 \\ \mathrm{H} & 13.638593 & 2.845463 & 5.820883 \\ \mathrm{C} & 10.394472 & 7.483133 & 12.250811 \\ \mathrm{C} & 13.637752 & 0.888263 & 10.079738 \\ \mathrm{H} & 13.001708 & 0.103407 & 9.611521 \\ \mathrm{H} & 14.429731 & 1.156338 & 9.346637 \\ \mathrm{C} & 12.934697 & 7.544442 & 7.937596 \\ \mathrm{H} & 13.671529 & 8.259216 & 7.552226 \\ \mathrm{C} & 13.359191 & 5.663190 & 6.153301 \\ \mathrm{C} & 12.954128 & 4.390825 & 3.965005 \\ \mathrm{H} & 14.045824 & 4.258881 & 3.890487 \\ \mathrm{C} & 7.912369 & 2.211095 & 8.400315 \\ \mathrm{C} & 15.401362 & 5.170858 & 7.604167 \\ \mathrm{H} & 15.399375 & 6.240726 & 7.869087 \\ \mathrm{C} & 13.300874 & 7.908192 & 4.905736 \\ \mathrm{H} & 12.239991 & 7.981826 & 5.195535 \\ \mathrm{C} & 12.275029 & 1.250004 & 12.683781 \\ \mathrm{H} & 11.457760 & 0.982901 & 13.392511 \\ \mathrm{C} & 6.965874 & 2.610736 & 7.221806 \\ \mathrm{C} & 5.960285 & 0.610573 & 9.077527 \\ \mathrm{H} & 5.434621 & 0.843062 & 8.139439 \\ \mathrm{C} & 15.973564 & 7.722324 & 4.105189 \\ \mathrm{H} & 17.026107 & 7.630584 & 3.787917 \\ \mathrm{C} & 11.296607 & 6.355072 & 12.702854 \\ \mathrm{H} & 10.832585 & 5.360599 & 12.520407 \\ \mathrm{H} & 11.531443 & 6.434978 & 13.785822 \\ \mathrm{H} & 12.259364 & 6.361587 & 12.143336 \\ \mathrm{C} & 15.209030 & 8.826607 & 3.700792 \\ \mathrm{H} & 15.653040 & 9.613697 & 3.067866 \\ \mathrm{C} & 5.997747 & -0.596939 & 11.198659 \\ \mathrm{H} & 5.529776 & -1.297267 & 11.911163 \\ \mathrm{C} & 13.864043 & 8.912678 & 4.105188 \\ \mathrm{H} & 13.242703 & 9.767105 & 3.786940 \\ \mathrm{C} & 8.920051 & 10.727093 & 13.720123 \\ \mathrm{H} & 8.941776 & 11.724511 & 13.226973 \\ \mathrm{H} & 9.620211 & 10.754376 & 14.582973 \\ \mathrm{H} & 7.892520 & 10.595009 & 14.133351 \\ \mathrm{C} & 7.233288 & 0.004420 & 11.499502 \\ \mathrm{H} & 7.742837 & -0.220608 & 12.451637\end{array}$




\begin{tabular}{|c|c|c|c|}
\hline C & 10.699461 & -0.281811 & \\
\hline $\mathrm{H}$ & 11.012639 & -1.316679 & \\
\hline & 9.874145 & 2.335272 & \\
\hline & 9.481067 & 3.313608 & \\
\hline & 14.261895 & 0.374409 & \\
\hline & 14.882857 & -0.525454 & \\
\hline & 6.299788 & 3.851544 & \\
\hline & 6.448532 & 4.591 & \\
\hline & 6.75 & & \\
\hline & 7.271910 & 0.721684 & \\
\hline & 10.7 & & \\
\hline & 10.10 & 3.7 & \\
\hline & 12.1 & & \\
\hline & 12.599269 & 3.4 & \\
\hline & 8.46 & & \\
\hline & 9.26 & & \\
\hline & 7.86 & 9.5 & \\
\hline H & 7.80 & & \\
\hline & 5.36 & -0.2 & 9.9 \\
\hline 11 & 4.38 & -0.7 & \\
\hline & 3.13 & 0.00 & 12.3 \\
\hline & 925 & -0.8 & \\
\hline & 13.571 & -0.35 & 13.3 \\
\hline & 10.943117 & 1.76 & \\
\hline $\mathrm{H}$ & 11.418975 & & \\
\hline & 13.161661 & 2.3 & 13.3 \\
\hline $\mathrm{H}$ & & & \\
\hline & 12.54 & 3.25 & 13.5 \\
\hline & 5.44 & 4.1 & \\
\hline & 4.943593 & & \\
\hline C & 11.364542 & 0.458541 & 6.3 \\
\hline & 12.199333 & 0.0 & \\
\hline $\mathrm{C}$ & 14.285 & 2.72 & 12.3 \\
\hline $\mathrm{H}$ & 14.923415 & 3.5 & 12.7 \\
\hline $\mathrm{C}$ & 5.238224 & & 5.0 \\
\hline $\mathrm{H}$ & 4.570609 & 3.490879 & 4.20593 \\
\hline & 15.147785 & 1.478900 & 12.0 \\
\hline $\mathrm{H}$ & 15.977237 & 1.741616 & 11.32024 \\
\hline & 15.618507 & 1.107704 & 12.95752 \\
\hline $\mathrm{C}$ & & 2.002039 & 5.09426 \\
\hline $\mathrm{H}$ & 5.749775 & 1.265519 & 4.28576 \\
\hline
\end{tabular}

Table S-12 Coordinates of optimized molecular structure for $\left({ }^{\mathrm{Tr}} \mathrm{L}\right) \mathrm{Co}(\mathrm{NAd})(3)$.

$\mathrm{E}=-4096.552099588586$ a.u.

Charge $=0$, Spin multiplicity $=5$ 


$\begin{array}{lccr}\text { Co } & 11.042754 & 3.711415 & 8.218442 \\ \mathrm{~N} & 9.269506 & 4.225756 & 9.034458 \\ \mathrm{~N} & 11.664166 & 5.659375 & 8.073927 \\ \mathrm{~N} & 11.984603 & 2.849634 & 9.414012 \\ \mathrm{C} & 9.165404 & 5.342809 & 9.870030 \\ \mathrm{C} & 12.657107 & 6.286828 & 7.390376 \\ \mathrm{C} & 9.216956 & 9.637613 & 12.682996 \\ \mathrm{C} & 14.123933 & 6.811622 & 5.384016 \\ \mathrm{C} & 11.253998 & 6.542964 & 9.090798 \\ \mathrm{C} & 9.805664 & 7.523119 & 10.870246 \\ \mathrm{C} & 12.442810 & 5.079264 & 5.113440 \\ \mathrm{C} & 8.144678 & 3.500701 & 9.191021 \\ \mathrm{C} & 7.278573 & 4.115483 & 10.155638 \\ \mathrm{H} & 6.300272 & 3.733767 & 10.473050 \\ \mathrm{C} & 14.420527 & 4.670850 & 6.770939 \\ \mathrm{C} & 15.464486 & 6.706592 & 4.960178 \\ \mathrm{H} & 16.068373 & 5.834235 & 5.253269 \\ \mathrm{C} & 11.051174 & 5.319344 & 5.109222 \\ \mathrm{H} & 10.592983 & 5.875867 & 5.940086 \\ \mathrm{C} & 7.781598 & 0.977141 & 10.619628 \\ \mathrm{H} & 8.735817 & 1.476940 & 10.853954 \\ \mathrm{C} & 9.120888 & 1.632147 & 7.780906 \\ \mathrm{C} & 9.611313 & 0.348596 & 8.094439 \\ \mathrm{H} & 9.105237 & -0.257341 & 8.860078 \\ \mathrm{C} & 12.693050 & 2.246327 & 10.478840 \\ \mathrm{C} & 16.420606 & 2.947876 & 7.842311 \\ \mathrm{H} & 17.204986 & 2.283611 & 8.242795 \\ \mathrm{C} & 13.675505 & 3.272173 & 11.133792 \\ \mathrm{H} & 13.088900 & 4.149748 & 11.487698 \\ \mathrm{H} & 14.378503 & 3.639940 & 10.354331 \\ \mathrm{C} & 10.237254 & 4.873502 & 4.049443 \\ \mathrm{H} & 9.154230 & 5.081485 & 4.075646 \\ \mathrm{C} & 7.921494 & 5.272200 & 10.585919 \\ \mathrm{H} & 7.560158 & 6.011225 & 11.313217 \\ \mathrm{C} & 7.145999 & 1.239666 & 9.382361 \\ \mathrm{C} & 10.107749 & 6.396534 & 9.913856 \\ \mathrm{C} & 8.756385 & 9.670586 & 11.351823 \\ \mathrm{H} & 8.158818 & 10.533969 & 11.008617 \\ \mathrm{C} & 11.710361 & 1.739994 & 11.585342 \\ \mathrm{H} & 11.096102 & 2.598817 & 11.941439 \\ \mathrm{H} & 11.013723 & 0.999637 & 11.128468 \\ \mathrm{C} & 9.983506 & 8.527659 & 13.084323 \\ \mathrm{H} & 10.363702 & 8.480078 & 14.120069 \\ \mathrm{C} & 9.033453 & 8.636244 & 10.436532 \\ \mathrm{C} & 16.407598 & 4.315474 & 8.173588 \\ & & & \end{array}$




$\begin{array}{cccc}\mathrm{H} & 17.178359 & 4.731060 & 8.845089 \\ \mathrm{C} & 12.080926 & 7.713840 & 9.054472 \\ \mathrm{H} & 11.991300 & 8.576401 & 9.727245 \\ \mathrm{C} & 15.413049 & 2.439751 & 7.009568 \\ \mathrm{H} & 15.392028 & 1.367107 & 6.754341 \\ \mathrm{C} & 14.417853 & 3.290351 & 6.490645 \\ \mathrm{H} & 13.634265 & 2.859688 & 5.852307 \\ \mathrm{C} & 10.287543 & 7.468344 & 12.204401 \\ \mathrm{C} & 13.528639 & 1.019669 & 9.988222 \\ \mathrm{H} & 12.838765 & 0.279183 & 9.523730 \\ \mathrm{H} & 14.230372 & 1.361995 & 9.196425 \\ \mathrm{C} & 12.953678 & 7.556613 & 7.984357 \\ \mathrm{H} & 13.708136 & 8.271154 & 7.633918 \\ \mathrm{C} & 13.395127 & 5.682158 & 6.184301 \\ \mathrm{C} & 12.993906 & 4.405022 & 3.995867 \\ \mathrm{H} & 14.084370 & 4.258650 & 3.932631 \\ \mathrm{C} & 7.824230 & 2.228575 & 8.392192 \\ \mathrm{C} & 15.419573 & 5.160171 & 7.647678 \\ \mathrm{H} & 15.429156 & 6.229470 & 7.914531 \\ \mathrm{C} & 13.383172 & 7.938720 & 4.957637 \\ \mathrm{H} & 12.323921 & 8.033572 & 5.247196 \\ \mathrm{C} & 12.486612 & 1.097336 & 12.759178 \\ \mathrm{H} & 11.759169 & 0.753112 & 13.530431 \\ \mathrm{C} & 6.873281 & 2.560916 & 7.199879 \\ \mathrm{C} & 5.913862 & 0.605228 & 9.127987 \\ \mathrm{H} & 5.376151 & 0.800419 & 8.188105 \\ \mathrm{C} & 16.052851 & 7.703839 & 4.158500 \\ \mathrm{H} & 17.103853 & 7.593082 & 3.842363 \\ \mathrm{C} & 11.130929 & 6.305056 & 12.679266 \\ \mathrm{H} & 10.624306 & 5.331064 & 12.498724 \\ \mathrm{H} & 11.353580 & 6.385560 & 13.764785 \\ \mathrm{H} & 12.099716 & 6.261521 & 12.132564 \\ \mathrm{C} & 15.311913 & 8.827381 & 3.762923 \\ \mathrm{H} & 15.773251 & 9.610802 & 3.137948 \\ \mathrm{C} & 5.992161 & -0.535745 & 11.284477 \\ \mathrm{H} & 5.543460 & -1.222149 & 12.022444 \\ \mathrm{C} & 13.968641 & 8.938039 & 4.166292 \\ \mathrm{H} & 13.365994 & 9.808290 & 3.855175 \\ \mathrm{C} & 8.873236 & 10.749396 & 13.650979 \\ \mathrm{H} & 8.930939 & 11.748513 & 13.164201 \\ \mathrm{H} & 9.553047 & 10.754784 & 14.530183 \\ \mathrm{H} & 7.833363 & 10.639778 & 14.039089 \\ \mathrm{C} & 7.219013 & 0.096865 & 11.555875 \\ \mathrm{H} & 7.741252 & -0.089554 & 12.509439 \\ \mathrm{C} & 10.722255 & -0.191059 & 7.419010 \\ \mathrm{H} & 11.067587 & -1.205938 & 7.677706 \\ & & & \end{array}$




$\begin{array}{lccr}\mathrm{C} & 9.797933 & 2.373403 & 6.766564 \\ \mathrm{H} & 9.339160 & 3.294717 & 6.371894 \\ \mathrm{C} & 14.302550 & 0.378451 & 11.163447 \\ \mathrm{H} & 14.889176 & -0.489519 & 10.781977 \\ \mathrm{C} & 6.170646 & 3.778890 & 7.100322 \\ \mathrm{H} & 6.294964 & 4.545557 & 7.881096 \\ \mathrm{C} & 6.693161 & 1.606959 & 6.169714 \\ \mathrm{H} & 7.238949 & 0.649624 & 6.212379 \\ \mathrm{C} & 10.795013 & 4.172225 & 2.969436 \\ \mathrm{H} & 10.156766 & 3.816385 & 2.143504 \\ \mathrm{C} & 12.183781 & 3.945753 & 2.945937 \\ \mathrm{H} & 12.645599 & 3.420076 & 2.092738 \\ \mathrm{C} & 8.515193 & 8.721754 & 9.016184 \\ \mathrm{H} & 9.347856 & 8.696111 & 8.277220 \\ \mathrm{H} & 7.941775 & 9.660143 & 8.855147 \\ \mathrm{H} & 7.847551 & 7.864561 & 8.773680 \\ \mathrm{C} & 5.342333 & -0.273270 & 10.069339 \\ \mathrm{H} & 4.372679 & -0.748542 & 9.845229 \\ \mathrm{C} & 13.305112 & -0.106040 & 12.239342 \\ \mathrm{H} & 12.621663 & -0.877140 & 11.812034 \\ \mathrm{H} & 13.852543 & -0.589013 & 13.082255 \\ \mathrm{C} & 10.907013 & 1.820679 & 6.083383 \\ \mathrm{H} & 11.362315 & 2.395127 & 5.260181 \\ \mathrm{C} & 13.442139 & 2.141226 & 13.378805 \\ \mathrm{H} & 13.986301 & 1.698063 & 14.245800 \\ \mathrm{H} & 12.858738 & 3.006395 & 13.770423 \\ \mathrm{C} & 5.312559 & 4.035313 & 6.014008 \\ \mathrm{H} & 4.780150 & 5.000171 & 5.961319 \\ \mathrm{C} & 11.377283 & 0.540105 & 6.414751 \\ \mathrm{H} & 12.237445 & 0.107198 & 5.878513 \\ \mathrm{C} & 14.445050 & 2.623349 & 12.306430 \\ \mathrm{H} & 15.135371 & 3.376935 & 12.752172 \\ \mathrm{C} & 5.137441 & 3.076354 & 5.003880 \\ \mathrm{H} & 4.466497 & 3.277839 & 4.151527 \\ \mathrm{C} & 15.261004 & 1.419404 & 11.784092 \\ \mathrm{H} & 16.000627 & 1.760626 & 11.022604 \\ \mathrm{H} & 15.840192 & 0.956020 & 12.617473 \\ & 5.833397 & 1.856913 & 5.088515 \\ \mathrm{H} & 5.711065 & 1.092729 & 4.301573\end{array}$

Table S-13. Coordinates of optimized molecular structure for $\left({ }^{\mathrm{Tr}} \mathrm{L}\right) \mathrm{Co}(\mathrm{NHAd})(\mathbf{3 a})$.

$\mathrm{E}=-2861.91737336$ a.u.

$\mathrm{G}=-2860.912123$ a.u.

Charge $=0$, Spin multiplicity $=4$ 


\begin{tabular}{|c|c|c|c|}
\hline $\mathrm{Co}$ & 0.13189700 & -0.42122000 & 0.49088600 \\
\hline $\mathrm{N}$ & -1.33953100 & 0.19322000 & -0.74032700 \\
\hline $\mathrm{N}$ & 1.55958700 & 0.55095300 & -0.53239700 \\
\hline N & -0.23886400 & -0.40786500 & 2.29773000 \\
\hline $\mathrm{C}$ & -1.28383900 & 1.53549100 & -1.19579000 \\
\hline $\mathrm{C}$ & 2.91706400 & 0.42733200 & -0.60058600 \\
\hline $\mathrm{C}$ & -0.37716300 & 6.07918300 & -3.42712300 \\
\hline $\mathrm{C}$ & 5.16420100 & -0.70710200 & -0.38376200 \\
\hline $\mathrm{C}$ & 1.21919200 & 1.79948900 & -1.11497300 \\
\hline $\mathrm{C}$ & -0.20305900 & 3.58977000 & -2.07835700 \\
\hline $\mathrm{C}$ & 3.17297900 & -2.10993200 & -0.74765000 \\
\hline $\mathrm{C}$ & -2.61495500 & -0.24029000 & -0.90149200 \\
\hline $\mathrm{C}$ & -3.43828500 & 0.82447900 & -1.40990700 \\
\hline $\mathrm{H}$ & -4.49444100 & 0.74917400 & -1.62224900 \\
\hline $\mathrm{C}$ & 3.41298000 & -0.79789800 & 1.48313200 \\
\hline $\mathrm{C}$ & 6.17042400 & -0.75775800 & 0.59787400 \\
\hline $\mathrm{H}$ & 5.90467200 & -0.81550900 & 1.64691100 \\
\hline $\mathrm{C}$ & 2.22732700 & -2.13256700 & -1.79129000 \\
\hline $\mathrm{H}$ & 1.74523600 & -1.21529000 & -2.10406200 \\
\hline $\mathrm{C}$ & -4.89733100 & -0.93720200 & 0.80745600 \\
\hline $\mathrm{H}$ & -4.13975300 & -0.35565200 & 1.31966600 \\
\hline $\mathrm{C}$ & -2.13592500 & -2.46762100 & 0.22709100 \\
\hline $\mathrm{C}$ & -2.56492800 & -2.92870700 & 1.48048900 \\
\hline $\mathrm{H}$ & -3.58513700 & -2.76366900 & 1.80341600 \\
\hline $\mathrm{C}$ & -0.77578600 & 0.72570800 & 3.06758500 \\
\hline $\mathrm{C}$ & 3.08497100 & -0.64843300 & 4.30242400 \\
\hline $\mathrm{H}$ & 2.95858100 & -0.59230100 & 5.38037500 \\
\hline $\mathrm{C}$ & -0.10636400 & 2.05111700 & 2.61094400 \\
\hline $\mathrm{H}$ & -0.28430100 & 2.18529800 & 1.53625200 \\
\hline $\mathrm{H}$ & 0.97918300 & 1.96608100 & 2.75433100 \\
\hline $\mathrm{C}$ & 1.89218000 & -3.33723900 & -2.43926400 \\
\hline $\mathrm{H}$ & 1.15481200 & -3.32586800 & -3.23799300 \\
\hline $\mathrm{C}$ & -2.60923400 & 1.93310500 & -1.58985600 \\
\hline $\mathrm{H}$ & -2.87961800 & 2.90374100 & -1.98096800 \\
\hline $\mathrm{C}$ & -4.53214400 & -1.71250200 & -0.31736000 \\
\hline $\mathrm{C}$ & -0.09065100 & 2.25941200 & -1.38638800 \\
\hline $\mathrm{C}$ & -0.36807500 & 4.86560000 & -4.14617900 \\
\hline $\mathrm{H}$ & -0.42285800 & 4.88923100 & -5.23272900 \\
\hline $\mathrm{C}$ & -2.31098800 & 0.86765800 & 2.84744500 \\
\hline $\mathrm{H}$ & -2.49354800 & 1.00375400 & 1.77301600 \\
\hline $\mathrm{H}$ & -2.79499300 & -0.07161800 & 3.15164600 \\
\hline $\mathrm{C}$ & -0.28804000 & 6.02148800 & -2.02282300 \\
\hline $\mathrm{H}$ & -0.28490000 & 6.94606800 & -1.44973500 \\
\hline $\mathrm{C}$ & -0.28502800 & 3.62068000 & -3.49425200 \\
\hline $\mathrm{C}$ & 3.55435500 & 0.46782900 & 3.57972400 \\
\hline $\mathrm{H}$ & 3.79169500 & 1.39344400 & 4.09773600 \\
\hline
\end{tabular}




\begin{tabular}{|c|c|c|c|}
\hline $\mathrm{C}$ & 2.43388500 & 2.46277200 & -1.49728800 \\
\hline $\mathrm{H}$ & 2.49210900 & 3.43477700 & -1.96582600 \\
\hline $\mathrm{C}$ & 2.76740600 & -1.82640900 & 3.60863400 \\
\hline $\mathrm{H}$ & 2.38293200 & -2.69057100 & 4.14478700 \\
\hline $\mathrm{C}$ & 2.93111800 & -1.89795800 & 2.21213800 \\
\hline $\mathrm{H}$ & 2.66832100 & -2.81607600 & 1.70593000 \\
\hline $\mathrm{C}$ & -0.19985400 & 4.79312600 & -1.33571900 \\
\hline $\mathrm{C}$ & -0.51688100 & 0.54398100 & 4.58562200 \\
\hline $\mathrm{H}$ & -0.99066200 & -0.39279000 & 4.92089100 \\
\hline $\mathrm{H}$ & 0.56387600 & 0.44611100 & 4.75235200 \\
\hline $\mathrm{C}$ & 3.49141600 & 1.60508200 & -1.18019300 \\
\hline $\mathrm{H}$ & 4.54360600 & 1.77779300 & -1.34328000 \\
\hline $\mathrm{C}$ & 3.64569500 & -0.80164200 & -0.05381900 \\
\hline $\mathrm{C}$ & 3.80395500 & -3.32567100 & -0.39480200 \\
\hline $\mathrm{H}$ & 4.58092700 & -3.32428300 & 0.36392700 \\
\hline $\mathrm{C}$ & -3.05108200 & -1.70604900 & -0.77140100 \\
\hline $\mathrm{C}$ & 3.71304400 & 0.38997900 & 2.18970900 \\
\hline $\mathrm{H}$ & 4.06864900 & 1.25935100 & 1.64327600 \\
\hline $\mathrm{C}$ & 5.55394300 & -0.65432200 & -1.74188000 \\
\hline $\mathrm{H}$ & 4.79112100 & -0.64582800 & -2.51549300 \\
\hline $\mathrm{C}$ & -2.88578900 & 2.06048600 & 3.64657900 \\
\hline $\mathrm{H}$ & -3.97039500 & 2.13306700 & 3.47760300 \\
\hline $\mathrm{C}$ & -2.88483500 & -2.39937500 & -2.15638200 \\
\hline $\mathrm{C}$ & -5.54043500 & -2.43617500 & -0.98076700 \\
\hline $\mathrm{H}$ & -5.30200800 & -3.02403200 & -1.85883200 \\
\hline $\mathrm{C}$ & 7.53310300 & -0.74081600 & 0.23627500 \\
\hline $\mathrm{H}$ & 8.29323500 & -0.78396300 & 1.01222500 \\
\hline $\mathrm{C}$ & -0.11145100 & 4.77478300 & 0.17657500 \\
\hline $\mathrm{H}$ & -0.97339500 & 4.25819600 & 0.61355300 \\
\hline $\mathrm{H}$ & -0.08476500 & 5.79126200 & 0.58195100 \\
\hline $\mathrm{H}$ & 0.78345500 & 4.24296800 & 0.52072400 \\
\hline $\mathrm{C}$ & 7.90972100 & -0.67301800 & -1.11598900 \\
\hline $\mathrm{H}$ & 8.96008200 & -0.66028900 & -1.39507200 \\
\hline $\mathrm{C}$ & -7.22382200 & -1.63168000 & 0.59801700 \\
\hline $\mathrm{H}$ & -8.25310000 & -1.60061800 & 0.94574100 \\
\hline $\mathrm{C}$ & 6.90722200 & -0.63107800 & -2.10798000 \\
\hline $\mathrm{H}$ & 7.18103700 & -0.58772700 & -3.15898400 \\
\hline $\mathrm{C}$ & -0.49212800 & 7.40724200 & -4.15005800 \\
\hline $\mathrm{H}$ & 0.14119600 & 7.43027400 & -5.04543300 \\
\hline $\mathrm{H}$ & -0.20000500 & 8.24139000 & -3.50257300 \\
\hline $\mathrm{H}$ & -1.52515300 & 7.58837200 & -4.47877900 \\
\hline $\mathrm{C}$ & -6.22215500 & -0.89642100 & 1.26476100 \\
\hline $\mathrm{H}$ & -6.47300000 & -0.29223500 & 2.13285800 \\
\hline $\mathrm{C}$ & -1.68164200 & -3.61868800 & 2.33666500 \\
\hline $\mathrm{H}$ & -2.04000000 & -3.96432200 & 3.30309000 \\
\hline $\mathrm{C}$ & -0.79973600 & -2.73862700 & -0.16515400 \\
\hline
\end{tabular}




\begin{tabular}{|c|c|c|c|}
\hline $\mathrm{H}$ & -0.47581200 & -2.48395800 & -1.16823000 \\
\hline $\mathrm{C}$ & -1.07937000 & 1.74143400 & 5.38941600 \\
\hline $\mathrm{H}$ & -0.87919200 & 1.59157000 & 6.46031000 \\
\hline $\mathrm{C}$ & -2.65169400 & -1.68475900 & -3.34654800 \\
\hline $\mathrm{H}$ & -2.58119400 & -0.60321000 & -3.32736500 \\
\hline $\mathrm{C}$ & -2.96182800 & -3.80893200 & -2.22526500 \\
\hline $\mathrm{H}$ & -3.12444300 & -4.37905000 & -1.31465700 \\
\hline $\mathrm{C}$ & 2.49896200 & -4.54481800 & -2.05535400 \\
\hline $\mathrm{H}$ & 2.23447400 & -5.47590200 & -2.54900400 \\
\hline $\mathrm{C}$ & 3.46583900 & -4.53081500 & -1.02835200 \\
\hline $\mathrm{H}$ & 3.95973100 & -5.45214700 & -0.73112800 \\
\hline $\mathrm{C}$ & -0.26803500 & 2.33878000 & -4.30579300 \\
\hline $\mathrm{H}$ & 0.59964100 & 1.71741200 & -4.05017300 \\
\hline $\mathrm{H}$ & -0.23119800 & 2.55556500 & -5.37812000 \\
\hline $\mathrm{H}$ & -1.16191500 & 1.73288600 & -4.11013000 \\
\hline $\mathrm{C}$ & -6.87509700 & -2.39751500 & -0.52812200 \\
\hline $\mathrm{H}$ & -7.63682100 & -2.96123700 & -1.06077200 \\
\hline $\mathrm{C}$ & -2.60731400 & 1.84986000 & 5.15586100 \\
\hline $\mathrm{H}$ & -3.10528600 & 0.93251400 & 5.50375700 \\
\hline $\mathrm{H}$ & -3.01891600 & 2.68855700 & 5.73680800 \\
\hline $\mathrm{C}$ & 0.08178100 & -3.42643500 & 0.68432300 \\
\hline $\mathrm{H}$ & 1.08538200 & -3.64433100 & 0.33943200 \\
\hline $\mathrm{C}$ & -2.19793000 & 3.36361700 & 3.17067500 \\
\hline $\mathrm{H}$ & -2.60169100 & 4.22832800 & 3.71778900 \\
\hline $\mathrm{H}$ & -2.41027900 & 3.52245400 & 2.10314900 \\
\hline $\mathrm{C}$ & -2.49661300 & -2.35868000 & -4.57412300 \\
\hline $\mathrm{H}$ & -2.30921100 & -1.78558400 & -5.47868200 \\
\hline $\mathrm{C}$ & -0.35427000 & -3.86310400 & 1.95108000 \\
\hline $\mathrm{H}$ & 0.32491300 & -4.39672400 & 2.61051300 \\
\hline $\mathrm{C}$ & -0.66902800 & 3.25591200 & 3.40122700 \\
\hline $\mathrm{H}$ & -0.17884300 & 4.17996900 & 3.06399900 \\
\hline $\mathrm{C}$ & -2.57725500 & -3.76106800 & -4.63194500 \\
\hline $\mathrm{H}$ & -2.45508900 & -4.28111900 & -5.57842900 \\
\hline $\mathrm{C}$ & -0.39209400 & 3.04603200 & 4.91100700 \\
\hline $\mathrm{H}$ & 0.69233400 & 2.98351900 & 5.08619000 \\
\hline $\mathrm{H}$ & -0.77052100 & 3.90358800 & 5.48692700 \\
\hline $\mathrm{C}$ & -2.81253700 & -4.48563700 & -3.44518200 \\
\hline $\mathrm{H}$ & -2.87524200 & -5.57041100 & -3.47063500 \\
\hline $\mathrm{H}$ & -0.01164000 & -1.20851200 & 2.88788600 \\
\hline
\end{tabular}

Table S-14. Coordinates of optimized molecular structure for $\left[\left({ }^{\mathrm{Tr}} \mathrm{L}\right) \mathrm{Co}(\mathrm{NAd})\right]^{-}$.

$\mathrm{E}=-2861.35736058$ a.u.

$\mathrm{G}=-2860.358341$ a.u.

Charge $=-1$, Spin multiplicity $=4$ 


\begin{tabular}{|c|c|c|c|}
\hline Co & 0.09691100 & -0.34926900 & 0.45480300 \\
\hline $\mathrm{N}$ & -1.37382200 & 0.21588400 & -0.71749200 \\
\hline $\mathrm{N}$ & 1.52528900 & 0.55033800 & -0.56850600 \\
\hline $\mathrm{N}$ & -0.21339700 & -0.44251900 & 2.26325100 \\
\hline $\mathrm{C}$ & -1.33743700 & 1.56505700 & -1.12952900 \\
\hline $\mathrm{C}$ & 2.90100400 & 0.37177700 & -0.70189300 \\
\hline $\mathrm{C}$ & -0.44549200 & 6.16610700 & -3.33366600 \\
\hline $\mathrm{C}$ & 5.11752600 & -0.81408600 & -0.51562200 \\
\hline $\mathrm{C}$ & 1.19892500 & 1.78982600 & -1.16754500 \\
\hline $\mathrm{C}$ & -0.24989300 & 3.64011700 & -2.01645900 \\
\hline $\mathrm{C}$ & 3.09331100 & -2.17004400 & -0.85323600 \\
\hline $\mathrm{C}$ & -2.70108600 & -0.19583100 & -0.73165000 \\
\hline $\mathrm{C}$ & -3.52455900 & 0.88153400 & -1.12106000 \\
\hline $\mathrm{H}$ & -4.59949200 & 0.84303100 & -1.23364100 \\
\hline $\mathrm{C}$ & 3.41473900 & -0.88110400 & 1.38192000 \\
\hline $\mathrm{C}$ & 6.14387400 & -0.84672100 & 0.44665000 \\
\hline $\mathrm{H}$ & 5.89779200 & -0.87159900 & 1.50163100 \\
\hline $\mathrm{C}$ & 2.11667400 & -2.15530500 & -1.86845100 \\
\hline $\mathrm{H}$ & 1.63116100 & -1.22220600 & -2.12476700 \\
\hline $\mathrm{C}$ & -4.87696000 & -0.99591100 & 1.07854900 \\
\hline $\mathrm{H}$ & -4.08139800 & -0.45475900 & 1.57712000 \\
\hline $\mathrm{C}$ & -2.17412200 & -2.49080300 & 0.26130200 \\
\hline $\mathrm{C}$ & -2.55154300 & -3.04720700 & 1.49406000 \\
\hline $\mathrm{H}$ & -3.55267300 & -2.89440400 & 1.87821400 \\
\hline $\mathrm{C}$ & -0.58213200 & 0.72918300 & 3.05902900 \\
\hline $\mathrm{C}$ & 3.26681700 & -0.76667200 & 4.22142200 \\
\hline $\mathrm{H}$ & 3.20944600 & -0.72425500 & 5.30618900 \\
\hline $\mathrm{C}$ & 0.17634100 & 2.02151700 & 2.62805400 \\
\hline $\mathrm{H}$ & -0.00255400 & 2.20028100 & 1.56060900 \\
\hline $\mathrm{H}$ & 1.25461700 & 1.85824300 & 2.75679700 \\
\hline $\mathrm{C}$ & 1.75624800 & -3.33612600 & -2.54548600 \\
\hline $\mathrm{H}$ & 0.99389300 & -3.29541400 & -3.31961900 \\
\hline $\mathrm{C}$ & -2.67663800 & 1.99730200 & -1.36381100 \\
\hline $\mathrm{H}$ & -2.96852200 & 2.98421100 & -1.69753200 \\
\hline $\mathrm{C}$ & -4.58379700 & -1.69435300 & -0.11644300 \\
\hline $\mathrm{C}$ & -0.12963200 & 2.30548600 & -1.34598600 \\
\hline $\mathrm{C}$ & -0.62286400 & 4.96097600 & -4.04466100 \\
\hline $\mathrm{H}$ & -0.82878800 & 4.99889900 & -5.11351700 \\
\hline $\mathrm{C}$ & -2.11289900 & 0.97545900 & 2.85033600 \\
\hline $\mathrm{H}$ & -2.30749300 & 1.14336900 & 1.78379000 \\
\hline $\mathrm{H}$ & -2.65722400 & 0.07122600 & 3.15788100 \\
\hline $\mathrm{C}$ & -0.15230000 & 6.08544700 & -1.95820500 \\
\hline $\mathrm{H}$ & -0.00055700 & 7.00242900 & -1.39120500 \\
\hline $\mathrm{C}$ & -0.52827200 & 3.70654300 & -3.40972500 \\
\hline $\mathrm{C}$ & 3.65989000 & 0.36801000 & 3.48103300 \\
\hline $\mathrm{H}$ & 3.90692700 & 1.29526700 & 3.99249700 \\
\hline
\end{tabular}




\begin{tabular}{|c|c|c|c|}
\hline $\mathrm{C}$ & 2.40411200 & 2.39323200 & -1.63017700 \\
\hline $\mathrm{H}$ & 2.47131300 & 3.34355400 & -2.14231000 \\
\hline $\mathrm{C}$ & 2.92245100 & -1.94215500 & 3.53475800 \\
\hline $\mathrm{H}$ & 2.58042800 & -2.81569700 & 4.08433500 \\
\hline $\mathrm{C}$ & 2.99431600 & -1.99472400 & 2.12910600 \\
\hline $\mathrm{H}$ & 2.70309300 & -2.90807700 & 1.62809900 \\
\hline $\mathrm{C}$ & -0.05147200 & 4.84432300 & -1.29441400 \\
\hline $\mathrm{C}$ & -0.33269500 & 0.49033900 & 4.57586000 \\
\hline $\mathrm{H}$ & -0.87128200 & -0.41803800 & 4.88231200 \\
\hline $\mathrm{H}$ & 0.73792600 & 0.30718900 & 4.73340700 \\
\hline $\mathrm{C}$ & 3.46668700 & 1.49446300 & -1.33761300 \\
\hline $\mathrm{H}$ & 4.51262600 & 1.63364100 & -1.56797200 \\
\hline $\mathrm{C}$ & 3.60038300 & -0.87289400 & -0.16046900 \\
\hline $\mathrm{C}$ & 3.72067300 & -3.40196100 & -0.55334700 \\
\hline $\mathrm{H}$ & 4.51779200 & -3.42937500 & 0.18414000 \\
\hline $\mathrm{C}$ & -3.12940200 & -1.66602800 & -0.64773800 \\
\hline $\mathrm{C}$ & 3.72845400 & 0.30676700 & 2.08279300 \\
\hline $\mathrm{H}$ & 4.02059100 & 1.18631800 & 1.51575200 \\
\hline $\mathrm{C}$ & 5.48590700 & -0.80139200 & -1.88148600 \\
\hline $\mathrm{H}$ & 4.70736500 & -0.80148500 & -2.63814300 \\
\hline $\mathrm{C}$ & -2.58311100 & 2.19106700 & 3.68451900 \\
\hline $\mathrm{H}$ & -3.66030600 & 2.34271700 & 3.52026500 \\
\hline $\mathrm{C}$ & -3.04108600 & -2.30852500 & -2.06503600 \\
\hline $\mathrm{C}$ & -5.64049200 & -2.35491900 & -0.77057200 \\
\hline $\mathrm{H}$ & -5.45929200 & -2.88089100 & -1.70027400 \\
\hline $\mathrm{C}$ & 7.50056500 & -0.85204800 & 0.06073600 \\
\hline $\mathrm{H}$ & 8.27397700 & -0.88060000 & 0.82467400 \\
\hline $\mathrm{C}$ & 0.25862000 & 4.80441800 & 0.18792300 \\
\hline $\mathrm{H}$ & -0.52838900 & 4.27172400 & 0.73165500 \\
\hline $\mathrm{H}$ & 0.34665900 & 5.81437300 & 0.60440900 \\
\hline $\mathrm{H}$ & 1.19196500 & 4.26146300 & 0.38142700 \\
\hline $\mathrm{C}$ & 7.85395500 & -0.82474800 & -1.29921200 \\
\hline $\mathrm{H}$ & 8.89934900 & -0.82902000 & -1.59777700 \\
\hline $\mathrm{C}$ & -7.22308400 & -1.64655300 & 0.95238400 \\
\hline $\mathrm{H}$ & -8.23134700 & -1.62759900 & 1.35869800 \\
\hline $\mathrm{C}$ & 6.83252100 & -0.80053400 & -2.27266900 \\
\hline $\mathrm{H}$ & 7.08669100 & -0.78677800 & -3.32975900 \\
\hline $\mathrm{C}$ & -0.57909200 & 7.50746400 & -4.03100800 \\
\hline $\mathrm{H}$ & -0.09884300 & 7.49499000 & -5.01773400 \\
\hline $\mathrm{H}$ & -0.12458700 & 8.31146700 & -3.44057300 \\
\hline $\mathrm{H}$ & -1.63533100 & 7.76959500 & -4.18850700 \\
\hline $\mathrm{C}$ & -6.17312100 & -0.97383600 & 1.61250700 \\
\hline $\mathrm{H}$ & -6.36637000 & -0.43042700 & 2.53426800 \\
\hline $\mathrm{C}$ & -1.64669600 & -3.82558900 & 2.24520100 \\
\hline $\mathrm{H}$ & -1.96706700 & -4.24119500 & 3.19789500 \\
\hline $\mathrm{C}$ & -0.86191900 & -2.74917700 & -0.20926700 \\
\hline
\end{tabular}




$\begin{array}{lrrr}\mathrm{H} & -0.57595400 & -2.40473200 & -1.19660000 \\ \mathrm{C} & -0.79939900 & 1.70784100 & 5.41120600 \\ \mathrm{H} & -0.60784200 & 1.51797500 & 6.47789400 \\ \mathrm{C} & -2.83455900 & -1.53950100 & -3.22597000 \\ \mathrm{H} & -2.73328000 & -0.46363200 & -3.13968400 \\ \mathrm{C} & -3.15210700 & -3.71088100 & -2.20243500 \\ \mathrm{H} & -3.28932500 & -4.32283100 & -1.31462200 \\ \mathrm{C} & 2.36756500 & -4.55929100 & -2.21985700 \\ \mathrm{H} & 2.08461600 & -5.47236000 & -2.73712500 \\ \mathrm{C} & 3.35894600 & -4.58488300 & -1.21674500 \\ \mathrm{H} & 3.85359900 & -5.51888900 & -0.96188800 \\ \mathrm{C} & -0.69283800 & 2.43776100 & -4.22448500 \\ \mathrm{H} & 0.14425500 & 1.75112100 & -4.04707300 \\ \mathrm{H} & -0.74362500 & 2.66094300 & -5.29635300 \\ \mathrm{H} & -1.60488600 & 1.90016100 & -3.93569500 \\ \mathrm{C} & -6.94903600 & -2.33176700 & -0.24384700 \\ \mathrm{H} & -7.74836500 & -2.84438800 & -0.77380200 \\ \mathrm{C} & -2.31631300 & 1.93043600 & 5.18780300 \\ \mathrm{H} & -2.87724800 & 1.04431700 & 5.52046000 \\ \mathrm{H} & -2.66600700 & 2.78589900 & 5.78527200 \\ \mathrm{C} & 0.04001500 & -3.52593400 & 0.53327400 \\ \mathrm{H} & 1.02734600 & -3.72026500 & 0.13332600 \\ \mathrm{C} & -1.80865400 & 3.45507900 & 3.23618100 \\ \mathrm{H} & -2.15547200 & 4.33123400 & 3.80429600 \\ \mathrm{H} & -2.00749600 & 3.65073400 & 2.17286900 \\ \mathrm{C} & -2.74314100 & -2.15263000 & -4.49137700 \\ \mathrm{H} & -2.57219500 & -1.53871900 & -5.37260500 \\ \mathrm{C} & -0.34713800 & -4.06601700 & 1.77385600 \\ \mathrm{H} & 0.34999900 & -4.66519600 & 2.35421300 \\ \mathrm{C} & -0.29054400 & 3.23876100 & 3.45995400 \\ \mathrm{H} & 0.26032700 & 4.13565100 & 3.14180900 \\ \mathrm{C} & -2.86191500 & -3.54857200 & -4.61764400 \\ \mathrm{H} & -2.78845100 & -4.02201400 & -5.59364200 \\ \mathrm{C} & -0.02192200 & 2.97090300 & 4.96141900 \\ \mathrm{H} & 1.05622800 & 2.82456100 & 5.12626000 \\ \mathrm{C} & -0.33285500 & 3.83930100 & 5.56193700 \\ \mathrm{H} & -3.06802200 & -4.32809900 & -3.46035400 \\ & -3.15737300 & -5.40895500 & -3.53853800\end{array}$

Table S-15. Coordinates of optimized molecular structure for $\left({ }^{\mathrm{Ar}} \mathrm{L}\right) \mathrm{Co}(\mathrm{NHAd})(\mathbf{8 a})$.

$\mathrm{E}=-3245.44207794$ a.u.

$\mathrm{G}=-3244.339931$ a.u.

Charge $=0$, Spin multiplicity $=4$

$\begin{array}{llll}\text { Co } & -0.45721800 & -0.01509500 & 0.09095300\end{array}$ 


\begin{tabular}{|c|c|c|c|}
\hline $\mathrm{N}$ & -1.69723600 & -1.57085300 & -0.00419500 \\
\hline $\mathrm{N}$ & -1.96040900 & 1.32890200 & -0.02817300 \\
\hline $\mathrm{C}$ & -3.09573800 & -1.49030600 & -0.18709100 \\
\hline $\mathrm{C}$ & 2.58994400 & -4.32359400 & 0.97807200 \\
\hline $\mathrm{C}$ & 0.00662000 & -3.35881700 & 0.27556400 \\
\hline $\mathrm{C}$ & 1.78796400 & -3.64859000 & 1.92002900 \\
\hline $\mathrm{H}$ & 2.14503500 & -3.52014100 & 2.93685500 \\
\hline $\mathrm{C}$ & -1.35493800 & -2.88749400 & -0.06182400 \\
\hline $\mathrm{N}$ & 1.17327200 & 0.63264400 & 0.68058400 \\
\hline $\mathrm{C}$ & 0.50566000 & -3.17207300 & 1.59497600 \\
\hline $\mathrm{C}$ & -1.87255900 & 2.68282200 & 0.04245700 \\
\hline $\mathrm{C}$ & 1.80110200 & 4.86727900 & -0.60560300 \\
\hline $\mathrm{C}$ & 1.19505200 & 4.13855300 & -1.64811800 \\
\hline $\mathrm{H}$ & 1.67006500 & 4.10650200 & -2.62365700 \\
\hline $\mathrm{C}$ & -1.59509100 & -2.87050600 & 2.99299700 \\
\hline $\mathrm{H}$ & -2.05099900 & -3.71096000 & 2.47885900 \\
\hline $\mathrm{C}$ & -0.60348100 & 3.41477600 & -0.16755600 \\
\hline $\mathrm{C}$ & -0.49941800 & 2.56126300 & -2.57149300 \\
\hline $\mathrm{C}$ & -2.50710300 & -3.69261900 & -0.33750100 \\
\hline $\mathrm{H}$ & -2.50640100 & -4.76826900 & -0.44141800 \\
\hline $\mathrm{C}$ & -0.28461200 & -2.47127000 & 2.65248800 \\
\hline $\mathrm{C}$ & 2.08284200 & -4.49695700 & -0.32566800 \\
\hline $\mathrm{H}$ & 2.70895600 & -4.94800200 & -1.08923200 \\
\hline $\mathrm{C}$ & -3.85578000 & -0.30611700 & -0.08933100 \\
\hline $\mathrm{C}$ & 0.01323700 & 3.40428200 & -1.44897900 \\
\hline $\mathrm{C}$ & -5.35017700 & -0.44626600 & -0.13953400 \\
\hline $\mathrm{C}$ & -3.59840000 & -2.82055800 & -0.40297100 \\
\hline $\mathrm{H}$ & -4.63558900 & -3.07154700 & -0.57488600 \\
\hline $\mathrm{C}$ & 0.39756800 & -4.09491100 & -2.12310100 \\
\hline $\mathrm{C}$ & 0.81446500 & -4.00920500 & -0.69320300 \\
\hline $\mathrm{C}$ & -3.33299200 & 0.99327700 & 0.05125600 \\
\hline $\mathrm{C}$ & -0.42731100 & -3.02482400 & -4.16593100 \\
\hline $\mathrm{H}$ & -0.78532200 & -2.13384500 & -4.67387500 \\
\hline $\mathrm{C}$ & 0.29265300 & -1.37919500 & 3.33762600 \\
\hline $\mathrm{H}$ & 1.28619300 & -1.04475000 & 3.06254900 \\
\hline $\mathrm{C}$ & 2.52091100 & 0.32568300 & 0.16356100 \\
\hline $\mathrm{C}$ & -2.31556800 & -2.18625000 & 3.98672800 \\
\hline $\mathrm{H}$ & -3.32197900 & -2.50810000 & 4.23984300 \\
\hline $\mathrm{C}$ & -1.85248100 & 2.56558900 & -2.97649900 \\
\hline $\mathrm{H}$ & -2.56101600 & 3.21886800 & -2.47789700 \\
\hline $\mathrm{C}$ & 5.60054900 & 6.83524500 & -1.24727200 \\
\hline $\mathrm{H}$ & 6.55797900 & 7.32314300 & -1.40936700 \\
\hline $\mathrm{C}$ & -3.17300900 & 3.26431600 & 0.22248800 \\
\hline $\mathrm{H}$ & -3.37474900 & 4.32163600 & 0.31877300 \\
\hline $\mathrm{C}$ & -0.00892000 & 4.14484500 & 0.89263800 \\
\hline $\mathrm{C}$ & -0.57709200 & 4.12728300 & 2.27319800 \\
\hline
\end{tabular}




\begin{tabular}{|c|c|c|c|}
\hline $\mathrm{C}$ & 3.09813400 & 5.55905200 & -0.82419800 \\
\hline $\mathrm{C}$ & 4.07546200 & 5.59483800 & 0.19870200 \\
\hline $\mathrm{H}$ & 3.87807100 & 5.10404200 & 1.14776000 \\
\hline $\mathrm{C}$ & 6.04361400 & -4.49218100 & 2.58444800 \\
\hline $\mathrm{H}$ & 6.63758200 & -3.91647500 & 3.28929900 \\
\hline $\mathrm{C}$ & -0.07240100 & -2.95060700 & -2.81020900 \\
\hline $\mathrm{H}$ & -0.14557400 & -2.00200300 & -2.29082100 \\
\hline $\mathrm{C}$ & -4.08760800 & 2.20947600 & 0.21350000 \\
\hline $\mathrm{H}$ & -5.16337900 & 2.26552400 & 0.30247800 \\
\hline $\mathrm{C}$ & 5.31309200 & 6.22759500 & -0.00873600 \\
\hline $\mathrm{H}$ & 6.05338300 & 6.23738400 & 0.78696600 \\
\hline $\mathrm{C}$ & 3.39890100 & 6.17036500 & -2.06408800 \\
\hline $\mathrm{H}$ & 2.65652300 & 6.16981400 & -2.85776500 \\
\hline $\mathrm{C}$ & 0.51528200 & -5.31041300 & -2.83253000 \\
\hline $\mathrm{H}$ & 0.87062500 & -6.19852900 & -2.31591600 \\
\hline $\mathrm{C}$ & 0.40232400 & 1.70927300 & -3.24989400 \\
\hline $\mathrm{H}$ & 1.44593800 & 1.69512500 & -2.95304300 \\
\hline $\mathrm{C}$ & -1.73924100 & -1.08720300 & 4.65379800 \\
\hline $\mathrm{H}$ & -2.30217500 & -0.55493700 & 5.41642800 \\
\hline $\mathrm{C}$ & 1.18051600 & 4.86265400 & 0.65783100 \\
\hline $\mathrm{H}$ & 1.63535700 & 5.40580300 & 1.48069900 \\
\hline $\mathrm{C}$ & 3.95497600 & -4.79134200 & 1.33453000 \\
\hline $\mathrm{C}$ & -2.29291900 & 1.72731200 & -4.01442700 \\
\hline $\mathrm{H}$ & -3.33632500 & 1.74855100 & -4.31567400 \\
\hline $\mathrm{C}$ & 4.74605900 & -4.06605700 & 2.25694400 \\
\hline $\mathrm{H}$ & 4.35753000 & -3.15352100 & 2.69966300 \\
\hline $\mathrm{C}$ & -6.04273400 & -0.17109500 & -1.34336300 \\
\hline $\mathrm{C}$ & -7.44414600 & -0.32044200 & -1.37545900 \\
\hline $\mathrm{H}$ & -7.97419200 & -0.12089200 & -2.30435500 \\
\hline $\mathrm{C}$ & -1.60636000 & 4.12623000 & 4.91965300 \\
\hline $\mathrm{H}$ & -2.00609200 & 4.12556400 & 5.93031900 \\
\hline $\mathrm{C}$ & 5.80308200 & -6.38118100 & 1.06903300 \\
\hline $\mathrm{H}$ & 6.20475800 & -7.28083000 & 0.61029700 \\
\hline $\mathrm{C}$ & 4.50361100 & -5.95405500 & 0.74541500 \\
\hline $\mathrm{H}$ & 3.90740200 & -6.53705300 & 0.04868200 \\
\hline $\mathrm{C}$ & -1.21290200 & 5.33488100 & 4.31225500 \\
\hline $\mathrm{H}$ & -1.30992100 & 6.27338200 & 4.85188200 \\
\hline $\mathrm{C}$ & -0.70100000 & 5.33221700 & 3.00193200 \\
\hline $\mathrm{H}$ & -0.41485400 & 6.27075000 & 2.53397600 \\
\hline $\mathrm{C}$ & 2.40797500 & -0.64871700 & -1.03443800 \\
\hline $\mathrm{H}$ & 1.75369300 & -0.21018100 & -1.79968500 \\
\hline $\mathrm{H}$ & 1.94546200 & -1.58280300 & -0.69445900 \\
\hline $\mathrm{C}$ & -1.47652000 & 2.91870800 & 4.20573300 \\
\hline $\mathrm{H}$ & -1.77365700 & 1.97940200 & 4.66299200 \\
\hline $\mathrm{C}$ & -7.45937400 & -0.98295500 & 0.95161300 \\
\hline $\mathrm{H}$ & -8.00311700 & -1.29480000 & 1.84111300 \\
\hline
\end{tabular}




\begin{tabular}{|c|c|c|c|}
\hline $\mathrm{C}$ & 4.63664800 & 6.80236600 & -2.27478000 \\
\hline $\mathrm{H}$ & 4.84574300 & 7.27238500 & -3.23217800 \\
\hline $\mathrm{C}$ & -0.42925600 & -0.68783600 & 4.32597100 \\
\hline $\mathrm{H}$ & 0.02633600 & 0.16149700 & 4.82829100 \\
\hline $\mathrm{C}$ & 3.22464500 & 1.62796000 & -0.30859800 \\
\hline $\mathrm{H}$ & 3.30508100 & 2.32131800 & 0.54251700 \\
\hline $\mathrm{H}$ & 2.59178500 & 2.11702800 & -1.05353000 \\
\hline $\mathrm{C}$ & -8.17171400 & -0.71790900 & -0.23626800 \\
\hline $\mathrm{C}$ & -1.39132500 & 0.86173900 & -4.66493100 \\
\hline $\mathrm{H}$ & -1.73898400 & 0.20767300 & -5.46046800 \\
\hline $\mathrm{C}$ & 4.62236300 & 1.33233700 & -0.89592400 \\
\hline $\mathrm{H}$ & 5.08722300 & 2.27272200 & -1.22589900 \\
\hline $\mathrm{C}$ & -0.31879000 & -4.24465000 & -4.86317400 \\
\hline $\mathrm{H}$ & -0.59754000 & -4.30313400 & -5.91201800 \\
\hline $\mathrm{C}$ & 6.58025200 & -5.65239800 & 1.99129900 \\
\hline $\mathrm{H}$ & 7.58510900 & -5.98167400 & 2.24185400 \\
\hline $\mathrm{C}$ & -0.96671000 & 2.91796500 & 2.89734500 \\
\hline $\mathrm{H}$ & -0.86816000 & 1.97696600 & 2.36869200 \\
\hline $\mathrm{C}$ & 4.46422700 & 0.37443400 & -2.10427200 \\
\hline $\mathrm{H}$ & 5.44641700 & 0.16207300 & -2.55137200 \\
\hline $\mathrm{H}$ & 3.84720700 & 0.85180700 & -2.88082800 \\
\hline $\mathrm{C}$ & 3.42762300 & -0.34589400 & 1.23604300 \\
\hline $\mathrm{H}$ & 2.95074500 & -1.27455700 & 1.57112200 \\
\hline $\mathrm{H}$ & 3.51217900 & 0.32268000 & 2.10749600 \\
\hline $\mathrm{C}$ & 0.15684100 & -5.38784100 & -4.19105400 \\
\hline $\mathrm{H}$ & 0.24400600 & -6.33370400 & -4.71934600 \\
\hline $\mathrm{C}$ & -6.05812700 & -0.85861100 & 1.01690800 \\
\hline $\mathrm{C}$ & -0.03715100 & 0.85918400 & -4.27978500 \\
\hline $\mathrm{H}$ & 0.67198200 & 0.19780800 & -4.77090200 \\
\hline $\mathrm{C}$ & 3.80272000 & -0.94605500 & -1.63547000 \\
\hline $\mathrm{H}$ & 3.69070900 & -1.62956300 & -2.48937400 \\
\hline $\mathrm{C}$ & 4.83369900 & -0.65057300 & 0.65668500 \\
\hline $\mathrm{H}$ & 5.45292000 & -1.12873200 & 1.42914500 \\
\hline $\mathrm{C}$ & -5.29874200 & 0.27960400 & -2.58526400 \\
\hline $\mathrm{H}$ & -4.94153700 & 1.31074800 & -2.47244800 \\
\hline $\mathrm{H}$ & -5.94526800 & 0.23727200 & -3.46799200 \\
\hline $\mathrm{H}$ & -4.41305100 & -0.33885400 & -2.77315800 \\
\hline $\mathrm{C}$ & 4.69359500 & -1.60626600 & -0.55481300 \\
\hline $\mathrm{H}$ & 4.25318700 & -2.55658300 & -0.23600500 \\
\hline $\mathrm{H}$ & 5.68714200 & -1.82809900 & -0.97133400 \\
\hline $\mathrm{C}$ & 5.50249400 & 0.66592600 & 0.19043200 \\
\hline $\mathrm{H}$ & 5.62316900 & 1.35117200 & 1.04280400 \\
\hline $\mathrm{H}$ & 6.50612600 & 0.45671700 & -0.20844400 \\
\hline $\mathrm{C}$ & -9.68275300 & -0.83920900 & -0.27794300 \\
\hline $\mathrm{H}$ & -10.16067000 & 0.05841100 & 0.13944200 \\
\hline $\mathrm{H}$ & -10.03127200 & -1.69596800 & 0.31128400 \\
\hline
\end{tabular}




$\begin{array}{lrrr}\mathrm{H} & -10.04602000 & -0.95835900 & -1.30484300 \\ \mathrm{C} & -5.32640900 & -1.17281200 & 2.30703300 \\ \mathrm{H} & -4.75737100 & -2.10584700 & 2.21601500 \\ \mathrm{H} & -6.02766700 & -1.28016600 & 3.14113200 \\ \mathrm{H} & -4.60093000 & -0.39103300 & 2.56208700 \\ \mathrm{H} & 1.23262100 & 1.27197300 & 1.47831500\end{array}$

Table S-16 Coordinates of optimized molecular structure for [ $\left.\left.{ }^{\mathrm{Ar}} \mathrm{L}\right) \mathrm{Co}(\mathrm{NAd})\right]^{-}$.

\begin{tabular}{lrrr}
$\mathrm{E}=-3244.88913794$ a.u. & & \\
$\mathrm{G}=-3243.797247$ a.u. & & \\
Charge $=-1$, Spin multiplicity $=4$ & \\
\multicolumn{4}{l}{} \\
$\mathrm{Co}$ & -0.60761200 & -0.00224300 & 0.13972000 \\
$\mathrm{~N}$ & -1.82608700 & -1.50898100 & 0.06683900 \\
$\mathrm{~N}$ & -2.00695100 & 1.34056500 & -0.02370900 \\
$\mathrm{C}$ & -3.21675800 & -1.42697100 & -0.12906300 \\
$\mathrm{C}$ & 2.49655200 & -4.34430800 & 0.87474000 \\
$\mathrm{C}$ & -0.09628300 & -3.31842300 & 0.24571000 \\
$\mathrm{C}$ & 1.71937600 & -3.68030500 & 1.84639100 \\
$\mathrm{H}$ & 2.09520700 & -3.58671400 & 2.86070300 \\
$\mathrm{C}$ & -1.45976100 & -2.84384800 & -0.06000600 \\
$\mathrm{~N}$ & 1.11938300 & 0.02554400 & 0.25811900 \\
$\mathrm{C}$ & 0.44253100 & -3.16790400 & 1.55638800 \\
$\mathrm{C}$ & -1.83290300 & 2.71551000 & 0.08227900 \\
$\mathrm{C}$ & 1.95045700 & 4.71004700 & -0.62850100 \\
$\mathrm{C}$ & 1.29412000 & 4.00809400 & -1.65893100 \\
$\mathrm{H}$ & 1.75073700 & 3.95456600 & -2.64259800 \\
$\mathrm{C}$ & -1.64172200 & -2.78574100 & 2.96589000 \\
$\mathrm{H}$ & -2.16223500 & -3.54563200 & 2.39237100 \\
$\mathrm{C}$ & -0.52547900 & 3.36599000 & -0.15217300 \\
$\mathrm{C}$ & -0.49578700 & 2.54569900 & -2.57761100 \\
$\mathrm{C}$ & -2.59366000 & -3.62314400 & -0.37133300 \\
$\mathrm{H}$ & -2.59564900 & -4.69472600 & -0.52379300 \\
$\mathrm{C}$ & -0.30267300 & -2.47077400 & 2.64756200 \\
$\mathrm{C}$ & 1.96104200 & -4.47227700 & -0.42245500 \\
$\mathrm{H}$ & 2.56756900 & -4.90561000 & -1.21207900 \\
$\mathrm{C}$ & -3.97157300 & -0.21908100 & -0.03871800 \\
$\mathrm{C}$ & 0.08113200 & 3.32917600 & -1.44220400 \\
$\mathrm{C}$ & -5.46272800 & -0.32004600 & -0.08633200 \\
$\mathrm{C}$ & -3.70694600 & -2.74197400 & -0.40296700 \\
$\mathrm{H}$ & -4.74116100 & -2.99255700 & -0.59804500 \\
$\mathrm{C}$ & 0.26188700 & -3.98485200 & -2.18005800 \\
$\mathrm{C}$ & 0.69289600 & -3.95424000 & -0.75171800 \\
$\mathrm{C}$ & -3.38759700 & 1.07825200 & 0.08018300 \\
$\mathrm{C}$ & -0.57991500 & -2.83702100 & -4.17259300
\end{tabular}




\begin{tabular}{|c|c|c|c|}
\hline $\mathrm{H}$ & -0.95394600 & -1.92983100 & -4.63798100 \\
\hline $\mathrm{C}$ & 0.34789000 & -1.45867000 & 3.38867800 \\
\hline $\mathrm{H}$ & 1.36116700 & -1.17882100 & 3.12510100 \\
\hline $\mathrm{C}$ & 2.53663100 & -0.00888700 & 0.01452800 \\
\hline $\mathrm{C}$ & -2.31333400 & -2.10315000 & 3.99398700 \\
\hline $\mathrm{H}$ & -3.34598800 & -2.35512100 & 4.22068400 \\
\hline $\mathrm{C}$ & -1.85709500 & 2.63066300 & -2.94439500 \\
\hline $\mathrm{H}$ & -2.52313600 & 3.27331000 & -2.37901000 \\
\hline $\mathrm{C}$ & 5.84890400 & 6.46095900 & -1.32210800 \\
\hline $\mathrm{H}$ & 6.83163300 & 6.89053900 & -1.49805300 \\
\hline $\mathrm{C}$ & -3.07785700 & 3.34297800 & 0.29236800 \\
\hline $\mathrm{H}$ & -3.23238400 & 4.40829100 & 0.40580000 \\
\hline $\mathrm{C}$ & 0.13156100 & 4.06754300 & 0.89568100 \\
\hline $\mathrm{C}$ & -0.40374200 & 4.06732700 & 2.28923300 \\
\hline $\mathrm{C}$ & 3.27915600 & 5.33269100 & -0.86392700 \\
\hline $\mathrm{C}$ & 4.26524200 & 5.33121600 & 0.15195000 \\
\hline $\mathrm{H}$ & 4.04844100 & 4.86397700 & 1.10860600 \\
\hline $\mathrm{C}$ & 5.96319100 & -4.62174400 & 2.44553700 \\
\hline $\mathrm{H}$ & 6.56226900 & -4.09205400 & 3.18182200 \\
\hline $\mathrm{C}$ & -0.22143000 & -2.81531100 & -2.81614900 \\
\hline $\mathrm{H}$ & -0.31119200 & -1.89332500 & -2.25126900 \\
\hline $\mathrm{C}$ & -4.06409100 & 2.32051200 & 0.28373700 \\
\hline $\mathrm{H}$ & -5.13317300 & 2.43546500 & 0.40373500 \\
\hline $\mathrm{C}$ & 5.53472700 & 5.89068400 & -0.07217900 \\
\hline $\mathrm{H}$ & 6.27947200 & 5.87011800 & 0.71938600 \\
\hline $\mathrm{C}$ & 3.60678900 & 5.90880200 & -2.11434700 \\
\hline $\mathrm{H}$ & 2.86078700 & 5.93688800 & -2.90411700 \\
\hline $\mathrm{C}$ & 0.38762000 & -5.16672400 & -2.94305200 \\
\hline $\mathrm{H}$ & 0.74954000 & -6.07412300 & -2.46522900 \\
\hline $\mathrm{C}$ & 0.34565000 & 1.68318300 & -3.31799800 \\
\hline $\mathrm{H}$ & 1.39016000 & 1.58591200 & -3.03687600 \\
\hline $\mathrm{C}$ & -1.65937700 & -1.08987600 & 4.72259900 \\
\hline $\mathrm{H}$ & -2.18585500 & -0.55521100 & 5.50966200 \\
\hline $\mathrm{C}$ & 1.34701900 & 4.73391000 & 0.64308500 \\
\hline $\mathrm{H}$ & 1.83794900 & 5.25413900 & 1.46041600 \\
\hline $\mathrm{C}$ & 3.86221900 & -4.83555200 & 1.19289000 \\
\hline $\mathrm{C}$ & -2.36085400 & 1.87000100 & -4.01262900 \\
\hline $\mathrm{H}$ & -3.41241800 & 1.94663700 & -4.27570300 \\
\hline $\mathrm{C}$ & 4.66475000 & -4.17292300 & 2.15354600 \\
\hline $\mathrm{H}$ & 4.28423100 & -3.28798000 & 2.65480200 \\
\hline $\mathrm{C}$ & -6.17087600 & 0.05192700 & -1.25956300 \\
\hline $\mathrm{C}$ & -7.57667200 & -0.05874700 & -1.29151000 \\
\hline $\mathrm{H}$ & -8.10882800 & 0.21724900 & -2.20057800 \\
\hline $\mathrm{C}$ & -1.36182100 & 4.07774400 & 4.96135100 \\
\hline $\mathrm{H}$ & -1.73654800 & 4.08099600 & 5.98195200 \\
\hline $\mathrm{C}$ & 5.70903500 & -6.40903900 & 0.81563800 \\
\hline
\end{tabular}




\begin{tabular}{|c|c|c|c|}
\hline $\mathrm{H}$ & 6.10512600 & -7.27860000 & 0.29724600 \\
\hline $\mathrm{C}$ & 4.40745800 & -5.96142200 & 0.53049000 \\
\hline $\mathrm{H}$ & 3.80531800 & -6.50045900 & -0.19581500 \\
\hline $\mathrm{C}$ & -0.97127600 & 5.28181400 & 4.34436400 \\
\hline $\mathrm{H}$ & -1.04402000 & 6.22172300 & 4.88618300 \\
\hline $\mathrm{C}$ & -0.49324500 & 5.27314500 & 3.01982100 \\
\hline $\mathrm{H}$ & -0.20908100 & 6.20820700 & 2.54289400 \\
\hline $\mathrm{C}$ & 2.86841300 & -0.87730000 & -1.23751700 \\
\hline $\mathrm{H}$ & 2.29730600 & -0.48987500 & -2.09224500 \\
\hline $\mathrm{H}$ & 2.53227100 & -1.90404300 & -1.05589200 \\
\hline $\mathrm{C}$ & -1.26255700 & 2.86769200 & 4.24379300 \\
\hline $\mathrm{H}$ & -1.55687300 & 1.93067600 & 4.70765100 \\
\hline $\mathrm{C}$ & -7.59131800 & -0.88974500 & 0.97875300 \\
\hline $\mathrm{H}$ & -8.13601600 & -1.25254200 & 1.84919500 \\
\hline $\mathrm{C}$ & 4.87704000 & 6.46597900 & -2.34277400 \\
\hline $\mathrm{H}$ & 5.10556100 & 6.90767700 & -3.30939100 \\
\hline $\mathrm{C}$ & -0.32286400 & -0.77059300 & 4.41438300 \\
\hline $\mathrm{H}$ & 0.19045500 & 0.02022900 & 4.95568700 \\
\hline $\mathrm{C}$ & 3.01488100 & 1.45102200 & -0.26260600 \\
\hline $\mathrm{H}$ & 2.77454500 & 2.08209900 & 0.60229300 \\
\hline $\mathrm{H}$ & 2.45994600 & 1.84845400 & -1.11429300 \\
\hline $\mathrm{C}$ & -8.30735100 & -0.52193000 & -0.17893400 \\
\hline $\mathrm{C}$ & -1.51626300 & 1.00482400 & -4.73580000 \\
\hline $\mathrm{H}$ & -1.91368300 & 0.40905800 & -5.55389900 \\
\hline $\mathrm{C}$ & 4.53280900 & 1.47914900 & -0.55501700 \\
\hline $\mathrm{H}$ & 4.83461700 & 2.51872900 & -0.74479100 \\
\hline $\mathrm{C}$ & -0.46169000 & -4.02463300 & -4.92442400 \\
\hline $\mathrm{H}$ & -0.74601700 & -4.04002700 & -5.97372600 \\
\hline $\mathrm{C}$ & 6.49528000 & -5.74222900 & 1.77662800 \\
\hline $\mathrm{H}$ & 7.50143100 & -6.08800600 & 1.99870900 \\
\hline $\mathrm{C}$ & -0.78804300 & 2.86155000 & 2.92283500 \\
\hline $\mathrm{H}$ & -0.70904600 & 1.92295400 & 2.38564300 \\
\hline $\mathrm{C}$ & 4.83210200 & 0.60978900 & -1.80166600 \\
\hline $\mathrm{H}$ & 5.90730400 & 0.64045500 & -2.03287900 \\
\hline $\mathrm{H}$ & 4.29612400 & 1.01102400 & -2.67505600 \\
\hline $\mathrm{C}$ & 3.34357200 & -0.55206700 & 1.23098100 \\
\hline $\mathrm{H}$ & 3.00780800 & -1.57062800 & 1.44695300 \\
\hline $\mathrm{H}$ & 3.11894900 & 0.07204500 & 2.10826800 \\
\hline $\mathrm{C}$ & 0.02690500 & -5.19048400 & -4.30404200 \\
\hline $\mathrm{H}$ & 0.12063700 & -6.11304500 & -4.87190200 \\
\hline $\mathrm{C}$ & -6.18593100 & -0.79679000 & 1.03982300 \\
\hline $\mathrm{C}$ & -0.15631500 & 0.91517900 & -4.38282100 \\
\hline $\mathrm{H}$ & 0.50766800 & 0.24352800 & -4.92116500 \\
\hline $\mathrm{C}$ & 4.38645500 & -0.84963000 & -1.53305500 \\
\hline $\mathrm{H}$ & 4.59665200 & -1.46932200 & -2.41720700 \\
\hline $\mathrm{C}$ & 4.86258800 & -0.53568200 & 0.93361600 \\
\hline
\end{tabular}




$\begin{array}{lrrr}\mathrm{H} & 5.40895100 & -0.93714000 & 1.80003200 \\ \mathrm{C} & -5.42569100 & 0.55812300 & -2.47879200 \\ \mathrm{H} & -5.04412900 & 1.57242400 & -2.30593900 \\ \mathrm{H} & -6.07509800 & 0.57725000 & -3.36180300 \\ \mathrm{H} & -4.54993200 & -0.06510500 & -2.69483600 \\ \mathrm{C} & 5.15707400 & -1.40984900 & -0.31165900 \\ \mathrm{H} & 4.85424800 & -2.44733900 & -0.11993500 \\ \mathrm{H} & 6.23781500 & -1.41539400 & -0.51821600 \\ \mathrm{C} & 5.31212200 & 0.92118800 & 0.66128600 \\ \mathrm{H} & 5.12028600 & 1.54518700 & 1.54703000 \\ \mathrm{H} & 6.39384800 & 0.95370800 & 0.46257400 \\ \mathrm{C} & -9.82261100 & -0.60105400 & -0.21706100 \\ \mathrm{H} & -10.27781700 & 0.31151700 & 0.19473400 \\ \mathrm{H} & -10.19481000 & -1.44556400 & 0.37578700 \\ \mathrm{H} & -10.19069000 & -0.71520200 & -1.24363900 \\ \mathrm{C} & -5.45674700 & -1.20539400 & 2.30482300 \\ \mathrm{H} & -4.89824600 & -2.13685300 & 2.14791200 \\ \mathrm{H} & -6.15636700 & -1.35475300 & 3.13544000 \\ \mathrm{H} & -4.71601400 & -0.45091700 & 2.59637400\end{array}$




\section{References}

1. Chilton, N. F.; Anderson, R. P.; Turner, L. D.; Soncini, A.; Murray, K. S. J. Comput. Chem. 2013, 34 (13), 1164.

2. McCubbin, J. A.; Krokhin, O. V. Tetrahedron Lett. 2010, 51 (18), 2447.

3. Hennessy, E. T.; Betley, T. A. Science 2013, 340 (6132), 591.

4. Baek, Y.; Betley, T. A. J. Am. Chem. Soc. 2019, 141 (19), 7797.

5. Shimogaki, M.; Fujita, M.; Sugimura, T. Angew. Chem. Int. Ed. 2016, 55 (51), 15797.

6. Dryzhakov, M.; Hellal, M.; Wolf, E.; Falk, F. C.; Moran, J. J. Am. Chem. Soc. 2015, 137 (30), 9555.

7. Renny, J. S.; Tomasevich, L. L.; Tallmadge, E. H.; Collum, D. B. Angew. Chem. Int. Ed. 2013, 52 (46), 11998.

8. Kennedy, C. R.; Lehnherr, D.; Rajapaksa, N. S.; Ford, D. D.; Park, Y.; Jacobsen, E. N. J. Am. Chem. Soc. 2016, 138 (41), 13525.

9. Moffett, R. B.; White, J. L. J. Org. Chem. 1952, 17 (3), 407.

10. Hodgson, D. M.; Bray, C. D.; Kindon, N. D.; Reynolds, N. J.; Coote, S. J.; Um, J. M.; Houk, K. N. J. Org. Chem. 2009, 74 (3), 1019.

11. Lizza, J. R.; Bremerich, M.; McCabe, S. R.; Wipf, P. Org. Lett. 2018, 20 (21), 6760.

12. Grimme, S.; Ehrlich, S.; Goerigk, L. J. Comput. Chem. 2011, 32 (7), 1456.

13. U. Wedig, M. Dolg, H. Stoll, and H. Preuss in Quantum Chemistry: The Challenge of Transition Metals and Coordination Chemistry, Ed. A. Veillard, Reidel and Dordrecht: 1986, 79.

14. T. H. Dunning Jr. and P. J. Hay, in Modern Theoretical Chemistry, Ed. H. F. Schaefer III, Vol. 3 (Plenum, New York, 1977) 1-28.

15. Bergner, A.; Dolg, M.; Küchle, W.; Stoll, H.; Preuß, H. Mol. Phys. 1993, 80 (6), 1431.

16. Nieto, I.; Ding, F.; Bontchev, R. P.; Wang, H.; Smith, J. M. J. Am. Chem. Soc. 2008, 130 (9), 2716.

17. Ding, F.; Smith, J. M.; Wang, H. J. Org. Chem. 2009, 74 (7), 2679.

18. APEX3 Software Suite; Bruker AXS: Madison, WI, 2016

19. G. M. Sheldrick, Acta Crystal. 2015, 71, 3.

20. F. Neese, The ORCA program system, Wiley Interdiscip. Rev.: Comput. Mol. Sci., 2012, 2,73 .

21. (a) J. P. Perdew, Phys. Rev. B 1986, 33, 8822 (b) A. D. Becke, Phys Rev. A 1988, 38, 3098.

22. Weigend, F. Ahlrichs, R. Phys. Chem. Chem. Phys. 2005, 7 (18), 3297.

23. Weigend, F. Phys. Chem. Chem. Phys. 2006, 8 (9), 1057.

24. Neese, F.; Wennmohs, F.; Hansen, A.; Becker, U. Chem. Phys. 2009, 356 (1), 98. 